\title{
Rubiaceae Juss. do Parque Estadual das Várzeas do Rio Ivinhema, MS, Brasil
}

\author{
Zefa Valdivina Pereira ${ }^{1,3}$ e Luiza Sumiko Kinoshita ${ }^{2}$
}

Recebido: 30.07.2009; aceito: 28.02.2013

\begin{abstract}
Rubiaceae Juss. of Parque Estadual das Várzeas do Rio Ivinhema, Mato Grosso do Sul State, Brazil). This study aimed to identify genera and species of Rubiaceae occurring in the Parque Estadual das Várzeas do Rio Ivinhema, located in the Paraná river basin, between the coordinates 22K 0226719 UTM 7463768. Samples were collected monthly from September 2003 to October 2006. We found 45 species distributed in 24 genera. The most representative genera are Psychotria (10 species), Palicourea (4), and Borreria (3), followed by Alibertia, Chomelia, Coccocypselum, Coussarea, Diodela, Galianthe and Guettarda (2). Most of the species have a wide geographical distribution, however, for some species, such as Borreria flavovirens, Chomelia brasiliana, Psychotria anceps and Psychotria brachybotrya, this is the first record for Mato Grosso do Sul State.
\end{abstract}

Key words: floristic, Mato Grosso do Sul, new occurrences, taxonomy

RESUMO - (Rubiaceae Juss. do Parque Estadual das Várzeas do Rio Ivinhema, MS, Brasil). Este trabalho objetivou reconhecer os gêneros e espécies de Rubiaceae ocorrentes no Parque Estadual das Várzeas do Rio Ivinhema, MS, localizado na bacia do Paraná, entre as coordenadas 22K 0226719 UTM 7463768. As coletas foram mensais no período de setembro de 2003 a outubro 2006. Foram encontradas 45 espécies distribuídas em 24 gêneros. Os gêneros mais representativos foram Psychotria (10 espécies), Palicourea (4), Borreria (3), Alibertia, Chomelia, Coccocypselum, Coussarea, Diodela, Galianthe e Guettarda (2). A maioria das espécies amostradas apresenta ampla distribuição geográfica; contudo, algumas espécies como Borreria flavovirens, Chomelia brasiliana, Psychotria anceps e Psychotria brachybotrya tiveram sua ocorrência registrada pela primeira vez para o Estado do Mato Grosso do Sul.

Palavras-chave: florística, Mato Grosso do Sul, novas ocorrências, taxonomia

\section{Introdução}

Rubiaceae é a quarta maior família de angiospermas, englobando cerca de 12.000 espécies, quatro subfamílias e 650 gêneros (Delprete 1999). Distribui-se principalmente nas regiões tropicais e subtropicais, atingindo as regiões temperadas e frias da Europa e norte do Canadá (Mabberley 1997, Judd et al. 2002). No Brasil, está representada por 18 tribos, 101 gêneros e 1.010 espécies, distribuídas por diversas formações vegetacionais (Barroso et al. 1991).

São plantas de hábito variado, desde ervas, arbustos, subarbustos, árvores até lianas (Barroso et al.1991). Entretanto, cerca de $80 \%$ dos gêneros são integrados por plantas exclusivamente lenhosas, constituindo um dos mais importantes componentes da vegetação arbórea e arbustiva das florestas tropicais (Gentry 1988, Robbrecht 1988). Seus representantes destacam-se economicamente devido, fundamentalmente, a diversas culturas tropicais, em especial o café e o quinino (Lawrence 1977).

No Brasil, os tratamentos florísticos para a família são pontuais, sendo os mais completos aqueles publicados na Flora Brasiliensis por Muller (1881, 1888) e Schumann $(1888,1889)$. Os demais trabalhos restringem-se a floras locais e publicações de novos táxons (Smith \& Downs 1956, Sucre 1959, 1960-1961, 1971, Miotto 1975, Porto \& Mariath 1975, Porto et al. 1977, Dillenburg \& Porto 1985, Macias 1988, Barbosa \& Peixoto 1989, Jung-Mendaçolli 1994, 1999, Cabral 1996, Anunciação 1998, Germano Filho 1999, Taylor et al. 1999, Cabral \& Bacigalupo 2000, Zappi \& Nunes

1. Universidade Federal da Grande Dourados, Faculdade de Ciências Biológicas e Ambientais, Caixa Postal 322, $9825-070$ Dourados, MS, Brasil

2. Universidade Estadual de Campinas, Departamento de Botânica, Caixa Postal 6109, 13083-970 Campinas, SP, Brasil

3. Autor para correspondência: zefapereira@ufgd.edu.br 
2000, Costa \& Mamede 2002, Gomes 2003, Souza \& Sales 2002, 2004, Pereira \& Barbosa 2004, 2006, 2009, Delprete et al. 2004, 2005, Pereira et al. 2006a). Para o Estado do Mato Grosso do Sul trabalhos sobre Rubiaceae restringem-se ao de Delprete (2006) com a sinopses da família nos Estados de Mato Grosso e Mato Grosso do Sul.

O Parque Estadual das Várzeas do Rio Ivinhema - MS, foi criado como ação compensatória ambiental da Companhia Energética de São Paulo (CESP) devido à construção da Usina Hidrelétrica Eng. Sérgio Motta; representa a última área de ecossistema de Várzea da Bacia do Rio Paraná livre de represamento (Mato Grosso do Sul 2001). No entanto, as diferentes formas de uso anterior à criação do Parque como, por exemplo, a retirada de madeira de lei, construção de drenos, atividade agropecuária e o extrativismo de ginseng (Pfaffia glomerata (Sprengel) Pedersen), por meio de queimadas, conferiu à área uma intensa descaracterização.

Dada a riqueza de espécies desta família em território nacional e a carência de informações relativas à florística e taxonomia da vegetação do Parque das Várzeas do Rio Ivinhema, este trabalho tem como objetivos reconhecer os gêneros e espécies de Rubiaceae ocorrentes no Parque, ampliando assim o conhecimento sobre sua distribuição geográfica, e fornecer descrições, ilustrações e chaves analíticas para sua identificação.

\section{Material e métodos}

O Parque Estadual das Várzeas do Rio Ivinhema (PEVRI) situa-se na bacia do Paraná, no sudeste do Estado do Mato Grosso do Sul, entre as micro-regiões de Iguatemi e Nova Andradina, abrangendo os municípios de Naviraí, Jateí e Taquarussu (figura 1). Apresenta área de 73.315,15 ha, entre as coordenadas 22K 0226719 UTM 7463768, com altitude média de 300 m (Mato Grosso do Sul 2001).

O clima da região é considerado de transição entre o tropical e o subtropical e segundo a classificação de Köppen é do tipo Aw, úmido com inverno seco e verão chuvoso. A temperatura média anual varia de 20 a $22{ }^{\circ} \mathrm{C}$ e a precipitação média anual varia de 1.400 a $1.700 \mathrm{~mm}$, sendo novembro, dezembro e janeiro os meses mais chuvosos (Oliveira et al. 2000).

As formações florestais do Parque fazem parte dos domínios da Floresta Atlântica (IBGE 1992) e, de acordo com a classificação de Veloso et al. (1991), podem ser divididas em Floresta Estacional Semidecidual Submontana e Floresta Estacional
Semidecidual Aluvial (floresta paludícola) (Campos \& Souza 1997). O Parque apresenta ainda formações não florestais representadas pelas formações pioneiras com influência fluvial que, de acordo com IBGE (1992), ocorrem ao longo das planícies fluviais e ao redor das depressões aluvionares (pântanos, lagunas e lagoas). É possível verificar também a ocorrência de áreas de tensão ecológica caracterizadas pela transição e o contato da Floresta Estacional Semidecidual com o Cerrado (Campos \& Souza 1997).

Foram realizadas excursões mensais, no período de setembro de 2003 a outubro 2006, para coleta de material fértil de representantes de Rubiaceae. Os materiais foram coletados aleatoriamente em trilhas pré-existentes, margem do rio e caminhadas sem orientação pré-estabelecida tanto nos fragmentos como na área de várzeas e campos.

Os materiais botânicos foram herborizados, identificados com base em literatura especializada e comparados com as coleções dos herbários UEC, CGMS, UB, UFG, VIC e IAC. Os testemunhos encontram-se depositados no herbário DDMS e UEC. As siglas dos herbários estão de acordo com o Index Herbariorum (Holmgren et al. 1990). A grafia dos nomes dos autores seguiu a padronização recomentada por Brummitt \& Powell (1992).

As chaves para identificação de gêneros e espécies foram elaboradas com base nas características vegetativas e reprodutivas dos materiais coletados no PEVRI. A largura da lâmina foliar foi medida na sua maior extensão. Para a corola, as medidas foram feitas em todo o seu comprimento, incluindo os lobos. Para as espécies distílicas utilizou-se uma faixa de variação do tamanho da corola, filete e estilete de ambas os morfos florais, exceto para Psychotria deflexa DC. e Manettia cordifolia Mart. nas quais só foi encontrado um dos morfos florais.

\section{Resultados e Discussão}

No PEVRI foram reconhecidas 45 espécies de Rubiaceae distribuídas em 24 gêneros. Os gêneros mais representativos foram Psychotria com 10 espécies, Palicourea com quatro, Borreria com três, Alibertia, Chomelia, Coccocypselum, Coussarea, Diodella, Galianthe e Guettarda com duas; os demais gêneros apresentaram uma única espécie cada.

Rubiaceae Juss., Genera Plantarum: 196. 1789.

Árvores, arbustos ou ervas, ocasionalmente trepadeiras, glabras ou pilosas. Folhas simples, inteiras, opostas, raro alternas ou verticiladas, usualmente 


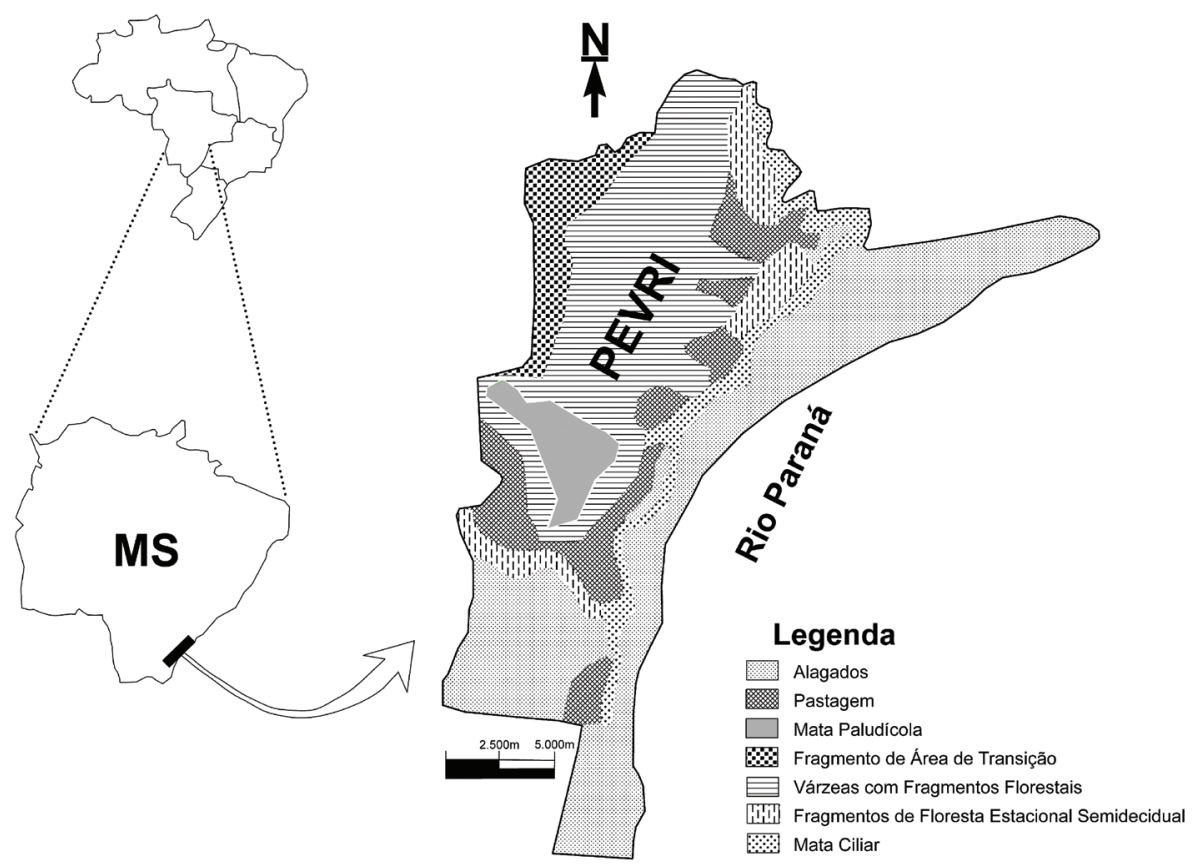

Figura 1. Localização geográfica do Parque Estadual das Várzeas do Rio Ivinhema, MS, Brasil.

Figure 1. Geographical location of the Parque Estadual das Várzeas do Rio Ivinhema, Mato Grosso do Sul State, Brazil.

pecioladas; estípulas variáveis, frequentemente caducas, livres ou concrescidas entre si, inteiras, bipartidas, recortadas, fimbriadas ou cerdosas, foliáceas ou reduzidas a setas glandulíferas. Inflorescências terminais ou axilares, geralmente cimosas, multifloras ou paucifloras, raramente flores solitárias; brácteas e bractéolas frequentemente decíduas; flores andróginas, raramente unissexuadas, diclamídeas, simpétalas, actinomorfas, raro zigomorfas, (3-)4-5(-8)-meras; cálice truncado, denteado ou lobado, raramente ausente, com ou sem coleteres; corola tubular, infundibuliforme, hipocrateriforme ou campanulada, prefloração imbricada, valvar ou contorcida; estames 4-5, raramente mais, epipétalos, raramente livres da corola, inclusos ou exsertos; anteras geralmente rimosas, excepcionalmente poricidas, dorsifixas ou basifixas; ovário ínfero, raramente súpero, dois, raramente três carpelos, dois ou mais lóculos, raramente um lóculo, um a muitos óvulos por lóculo, placentação apical, basal ou axial; disco nectarífero inteiro ou bipartido, anular, carnoso, raro reduzido a glândulas; estilete usualmente inteiro; estigma clavado, dilatado, capitado, truncado, discóide, bilobado ou bífido com papilas estigmáticas uniformemente distribuídas. Frutos deiscentes capsulares ou indeiscentes com pericarpo seco ou carnoso; semente plana, angulosa, reniforme, semicilíndrica, com ou sem alas, sulcada ou não; endosperma farto, carnoso ou córneo, parco ou ausente.

\section{Chave para identificação dos gêneros de Rubiaceae do PEVRI}

1. Ervas prostradas ou eretas

2. Estípulas inteiras

3. Flores heterostílicas

4. Frutos bacáceos azuis, polispérmicos

5. Coccocypselum

4. Frutos cápsula loculicida, duas sementes 16. Oldenlandia

3. Flores não heterostílicas

5. Estípulas foliáceas; cálice ausente 10. Galium

5. Estípulas não foliáceas; cálice presente 
6. Prefloração da corola valvar; ovário com um óvulo por lóculo; fruto drupáceo 12. Geophila

6. Prefloração da corola contorcida; ovário com muitos óvulos por lóculo; fruto cápsula loculicida

2. Estípulas fimbriadas ou cerdosas

7. Brácteas ovais, disposta em cruz; ovário tricarpelar 20. Richardia

7. Brácteas lanceoladas, nunca disposta em cruz; ovário bicarpelar

8. Frutos cápsulas circuncisas

15. Mitracarpus

8. Frutos cápsulas septicidas, esquizocárpicos ou secos indeiscentes

9. Frutos secos indeiscentes

23. Spermacoceodes

9. Frutos cápsulas septicidas ou esquizocárpicos

10. Inflorescências em cimeiras tirsóides, corimbiformes; flores heterostílicas

9. Galianthe

10. Inflorescências em cimeiras glomeriformes paucifloros ou multifloros; flores não heterostílicas

11. Inflorescências em cimeiras glomeriformes multifloras; fruto cápsula septicida, com as valvas concrescidas na base; sementes com sulco mediano longitudinal na superfície ventral

2. Borreria

11. Inflorescências em glomérulos paucifloros ou flores solitárias; fruto esquizocárpico, separando-se em dois mericarpos indeiscentes; sementes com depressão e com duas extensões apicais em forma de "y" na superfície ventral

7. Diodella

1. Árvores, subarbustos, arbustos ou trepadeiras

12. Trepadeiras

13. Estípulas fimbriadas; inflorescências em cimeiras paniculiformes, compostas de umbelas simples

8. Emmeorhiza

13. Estípulas inteiras; inflorescências unifloras ou em cimeiras corimbiformes

14. Frutos bacáceos; sementes ovais ou angulares

21. Sabicea

14. Fruto cápsula septicida; sementes não ovais, aladas

14. Manettia

12. Árvores, arbustos ou subarbustos

15. Prefloração da corola contorcida ou imbricada

16. Plantas dióicas

17. Ramos armados; espinhos axilares ou supra-axilares

19. Randia

17. Ramos inermes

18. Ovário 2-8-carpelar; placentação axial

1. Alibertia

18. Ovário 1-2-carpelar; placentação parietal

11. Genipa

16. Plantas hermafroditas

19. Inflorescência em dicásio; flores dispostas unilateralmente nos ramos

13. Guettarda

19. Inflorescências unifloras ou em cimeiras corimbiformes; com flores nunca dispostas unilateralmente nos ramos

24. Tocoyena

15. Prefloração da corola valvar

20. Fruto bacáceo, monospérmico

6. Coussarea

20. Fruto drupáceo com mais de uma semente

21. Ramos com espinhos nas axilas das folhas ou na parte apical

4. Chomelia

21. Ramos inermes

22. Folhas verticiladas; inflorescências em cimeiras glomeriformes

3. Cephalanthus

22. Folhas opostas; inflorescências em cimeiras paniculiformes, tirsóides ou corimbiformes

23. Corola gibosa na base, anel de tricomas internamente próximo a base;

presença de linha de articulação entre o pedicelo e o receptáculo

17. Palicourea

23. Corola reta na base, internamente com anel de tricomas na região mediana ou acima desta; ausência de linha de articulação entre o pedicelo e o receptáculo 
1. Alibertia A. Rich. ex DC. Mem. Soc. Hist. Nat. París 5: 234. 1830

Alibertia compreende cerca de 47 espécies, endêmicas da América tropical (Burger \& Taylor 1993). No Brasil, ocorrem aproximadamente 33 espécies distribuídas em todo o território nacional (Andersson 1992). Caracteriza-se pela dioicia, flores estaminadas frequentemente em fascículos e pistiladas solitárias, sésseis ou subsésseis, lobos da corola contorcidos no botão floral, e frutos bacáceos globosos. No PEVRI, somente Alibertia, Randia e Genipa apresentam plantas dióicas, contudo é possível diferenciá-los pelos ramos inermes, ovário 2-8 carpelar, estigma 2-8-partido e placentação axial em Alibertia.

Chave para identificação das espécies de Alibertia no PEVRI

1. Plantas arbóreas; folhas com 8-10 nervuras secundárias de cada lado; corola de $4-5 \mathrm{~cm}$ compr.; ovário 5-8-locular 1. A. edulis

1. Plantas subarbustivas; folhas com nervuras secundárias inconspícuas; corola 1-2 cm compr.; ovário 4-5-locular 2. A. sessilis

1.1. Alibertia edulis (Rich.) A. Rich. ex DC., Prodr. 4: 443. $1830 \equiv$ Genipa edulis Rich., Actes de la Société d'Histoire Naturelle de Paris 1: 107. 1792.

\section{Figura 2}

Árvore, 2-5 m alt. Ramos cilíndricos, glabros. Folhas pecioladas, pecíolo semicilíndrico, glabro, 1-2 cm compr.; lâmina elíptica, 8-15 × 2-5 cm, glabra, nervuras primária e secundárias proeminentes na face abaxial, 8-10 nervuras secundárias de cada lado, ápice acuminado, base aguda, margem inteira; estípulas persistentes, inteiras, triangulares, glabras, ápice acuminado. Flores estaminadas em inflorescências subsésseis, em fascículos terminais e flores solitárias nas flores pistiladas, brácteas ausentes; flores sésseis, 5-8-meras nas flores pistiladas, pentâmeras nas flores estaminadas; cálice com lobos reduzidos 0,1-0,3 mm compr.; corola hipocrateriforme, branca 1-5 cm compr., externamente pubescente, lobos triangulares, 2-3 cm compr.; estames inseridos no tubo da corola, subsésseis; anteras lanceoladas, 8-12 mm compr.; estaminódios 3-5 mm compr. nas flores pistiladas; ovário 5-8-locular, muitos óvulos por lóculo; disco nectarífero inteiro, 1-2 mm compr.; estilete cilíndrico, 2-3 cm compr., estigma 5-8-lobado. Fruto bacáceo, subgloboso, 4-8 × 3-7 cm, cálice persistente, marrom; sementes suborbiculares, castanho-escuras.

Material examinado: BRASIL. Mato Grosso Do Sul: Parque Estadual das Várzeas do Rio Ivinhema, 13-XI-2004, fl., Z.V. Pereira et al. 926 (DDMS); idem, 9-VII-2005, fl., Z.V. Pereira et al. 1345 (DDMS); idem, 5-II-2005, fr., Z.V. Pereira et al. 988 (DDMS idem, 5-II-2005, fl., Z.V. Pereira et al. 998 (DDMS); idem, 11-VI-2004, fl., Z.V. Pereira et al. 639 (DDMS); idem, 13-VII-2005, fl., Z.V. Pereira et al. 1354 (DDMS).

Material adicional examinado: BRASIL. AmAPÁ: Macapá, 24-X-1980, fr., B.V. Rabelo et al. 846 (UB). Maranhão: São Luíz, 28-VI-1979, fr., J.M. Poole 1698 (UB). Mato Grosso: Cáceres, 27-II-2002, fl., J.M. Resende \& V. Kinupp 1698 (CGMS). Мато Grosso do Sul: Campo Grande, 23-I-1993, fl., A. Oliveira s.n. (CGMS).

Alibertia edulis distribui-se do México até o Brasil (Dwyer 1980). No Brasil, é encontrada em quase todos os Estados (Andersson 1992). No PEVRI, está representada por vários indivíduos distribuídos nas áreas de transição próximas a estrada principal do Parque. Diferencia-se das demais espécies pelo porte arbóreo, estípulas inteiras, com ápice acuminado, folhas com 8-10 nervuras secundárias de cada lado, flores pistiladas solitárias e estaminadas em fascículos terminais e frutos subglobosos, grandes de 4-8 cm de comprimento. Floresce e frutifica o ano todo.

1.2. Alibertia sessilis (Vell.) K. Schum., Flora Brasiliensis 6(6):395. 1889 $\equiv$ Gardenia sessilis Vell. Florae Fluminensis 192, 3 t. 11. 1825.

Figuras 3-5

Subarbusto, ca. $40 \mathrm{~cm}$ alt. Ramos cilíndricos, glabros. Folhas subsésseis, pecíolo semicilíndrico, 1-2 mm compr., glabro; lâmina oblanceolada, 4-6 × 1,5-3 cm, glabra, nervuras primárias proeminentes em ambas as faces, nervuras secundárias inconspícuas, ápice obtuso, base atenuada, margem inteira; estípulas persistentes, triangulares, ápice acuminado. Flores estaminadas em inflorescências subsésseis em fascículos terminais e flores solitárias nas pistiladas; flores sésseis, pentâmera; cálice $2 \mathrm{~mm}$ compr., truncado; corola tubular, branca, 1-2 cm compr., glabra, lobos obtusos 2-3 mm compr.; flores estaminadas com estames inseridos no tubo da corola, subsésseis; antera lanceolada, 5-8 mm compr.; flor pistilada com ovário 4-5-locular, vários óvulos por 
lóculos; disco nectarífero inteiro, 0,5 mm compr., estilete cilíndrico, 0,6-1,0 $\mathrm{mm}$ compr. estigma 4-5-lobado. Fruto bacáceo, subgloboso, marrom, 2-3,5 × 2-2,9 cm, cálice persistente; sementes suborbiculares, castanho-escuras.

Material examinado: BRASIL. Mato Grosso Do Sul: Parque Estadual das Várzeas do Rio Ivinhema, 10-IX-2005, fl., Z.V. Pereira et al. 1483 (DDMS); Idem, 10-IX-2004, fr., Z.V. Pereira et al. 1486 (DDMS); Idem, 23-XI-2003, fr., Z.V. Pereira et al. 313 (DDMS).

Material adicional examinado: BRASIL. MAto Grosso Do Sul: Rio Negro, 27-VII-1998, fl., V.D. Pott 2376 (CGMS); Campo Grande, 11-IX-2002, fr., fl., L.C. Rodrigues 7 (CGMS); Idem, 28-IX-2002, fl., fr., L.C. Rodrigues 24 (CGMS); Idem, 2-XII-2001, fr., E.M.J. Costa s.n. (CGMS); Idem, 11-X-1989, fl., V.M. Resende et al. 5 (CGMS).

Alibertia sessilis distribui-se na Bolívia, Peru, Brasil e Paraguai (Missouri Botanical Garden 2007). No Brasil, distribui-se nos Estados de Minas Gerais, São Paulo e Mato Grosso do Sul (Missouri Botanical Garden 2007). No PEVRI, foram amostrados poucos indivíduos próximos à entrada principal do Parque. Diferencia-se de $A$. edulis pelo porte, folhas com nervuras secundárias inconspícuas, corola pequena de 1-2 cm compr., ovário 4-5-locular e fruto subgloboso de 2-3,5 cm compr. No PEVRI, floresce de agosto a dezembro e frutifica de setembro a abril.

2. Borreria G. Mey., Primitiae Florae Essequeboensis: 79 , t. 1.1818.

Este gênero apresenta cerca de 150 espécies com distribuição pantropical (Porto et al. 1977, Burger \& Taylor 1993, Delprete et al. 2005, Bacigalupo \& Cabral 2007). No Brasil, ocorrem 40 espécies distribuídas no Distrito Federal e nos Estados do Amazonas, Pará, Piauí, Bahia, Espírito Santo, Minas Gerais, São Paulo, Goiás, Distrito Federal e Rio Grande do Sul (Dimitri 1959, Andersson 1992). No PEVRI, está representado por três espécies amplamente distribuídas.

Caracteriza-se pela presença de folhas sésseis ou subsésseis, relativamente estreitas (exceto B. latifolia e B. flavovirens), estípulas fimbriadas, inflorescência em glomérulos terminais e axilares nos nós superiores ou pleiotirsos corimbiformes, flores sésseis ou subsésseis, tetrâmeras, cálice com 2-4 sépalas e fruto cápsula septicida com as valvas concrescidas na base. No PEVRI, as espécies desses gêneros são, vegetativamente, muito semelhantes às espécies do gêneros Mitracarpus, Diodella, Galianthe e Spermacoceodes; entretanto, a deiscência do fruto e o tipo de inflorescência constituem caracteres de distinção entre esses gêneros.

Chave para identificação das espécies de Borreria no PEVRI

1. Lâmina foliar elíptica ou lanceolada; duas brácteas foliáceas; cálice com quatro sépalas; estigma bífido

2. Ervas eretas; inflorescências paucifloras; sépalas triangulares de 2-3,5 mm compr.; sementes com superfície dorsal reticulada 2. B. latifolia

2. Ervas escandentes; inflorescências multifloras; sépalas lanceoladas de 5-7 mm compr.; sementes com superfície dorsal lisa 1. B. flavovirens

1. Lâmina foliar lanceolada; mais de duas brácteas foliáceas; cálice com duas sépalas; estigma capitado, levemente bilobado 3. B. verticillata

2.1. Borreria flavovirens Bacigalupo \& E.L. Cabral, Hickenia 2(56): 261. 1998.

Figuras 6-9

Ervas perenes, escandentes, ca. $70 \mathrm{~cm}$ alt. Ramos tetragonais, pubescentes. Folhas sésseis ou subsésseis, verde-amareladas; lâmina elíptica ou lanceolada, 2-5 × 1-3 cm, híspida, nervuras primária e secundárias proeminentes na face adaxial, ápice agudo, base atenuada, margem inteira, estípulas 7-9-fimbriadas, pubescentes. Inflorescências sésseis, em cimeiras glomeriformes, terminais e axilares, multifloros, duas brácteas foliáceas; flores sésseis; cálice com 4 sépalas iguais, lanceoladas, 5-7 mm compr., ciliados; corola infundibuliforme, branca, 7-9 mm compr., externamente glabra, internamente com tricomas nos lobos, lobos triangulares, 2-3 mm compr., reflexo na flor em antese; estames exsetos, inseridos na fauce da corola, filete cilíndrico, $2 \mathrm{~mm}$ compr.; antera elíptica; ovário bilocular, um óvulo por lóculo; disco nectarífero proeminente, $1 \mathrm{~mm}$ compr., bipartido; estilete cilíndrico, exserto, 3-8 mm compr.; estigma bífido. Fruto cápsula septicida, turbinada, 3-4,5 × 2-3,5 mm, cálice persistente; sementes plano-convexas, elípticas, superfície dorsal fortemente convexa, lisa, superfície ventral com profundo sulco longitudinal. 


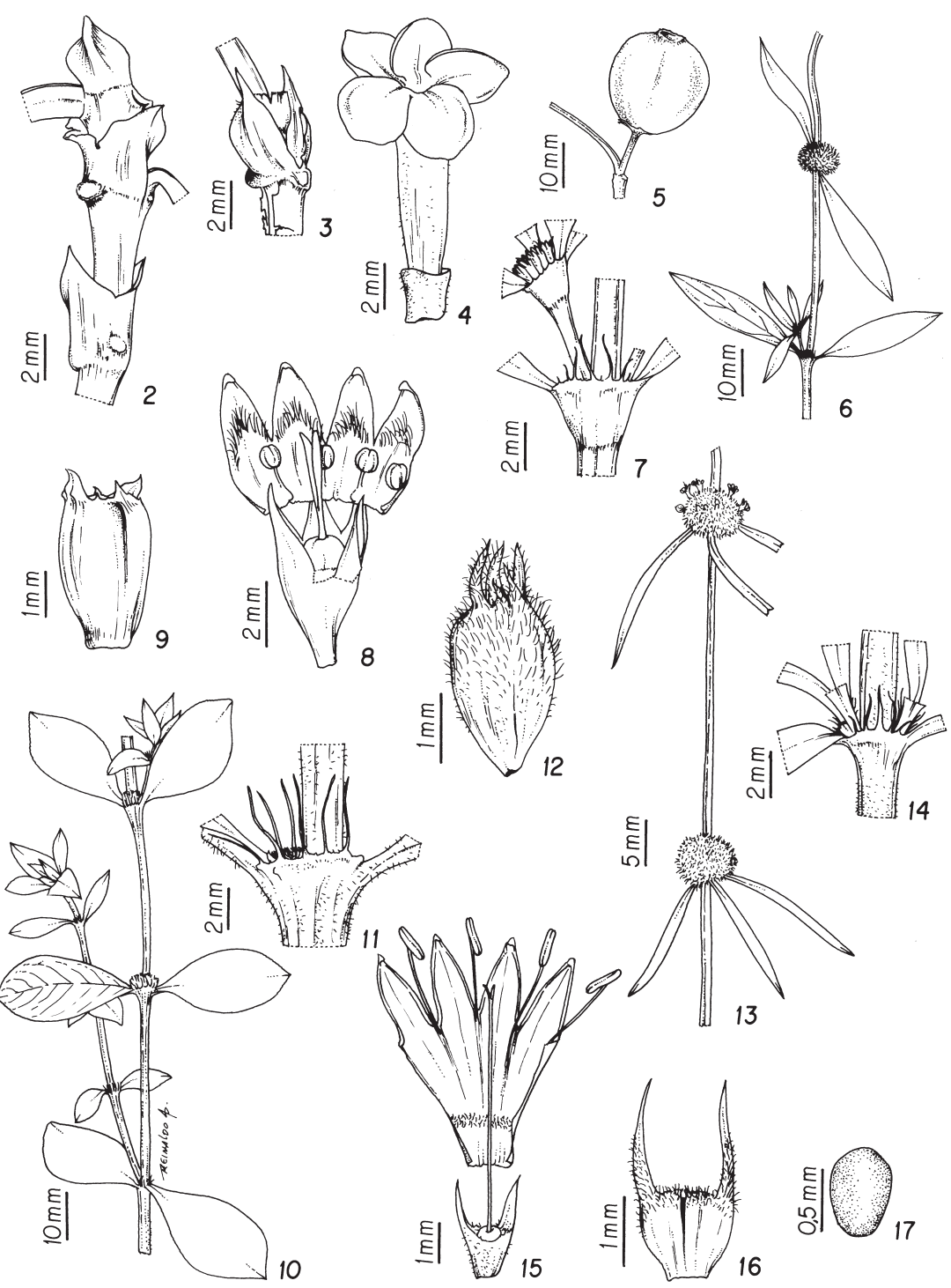

Figuras 2-17. Espécies de Rubiaceae do Parque Estadual das Várzeas do Rio Ivinhema, MS, Brasil. 2. Alibertia edulis (Z.V. Pereira et al. 926), ramos com estípulas inteiras, triangulares com ápice acuminado. 3-5. Alibertia sessilis (Z.V. Pereira et al. 1483, 1486). 3. Estípulas inteiras, triangulares com ápice acuminado; 4. Corola tubular com lobos obtusos; 5. Fruto bacáceo. 6-9. Borreria flavovirens (Z.V. Pereira et al. 615). 6. Ramos e inflorescências em cimeiras glomeriformes guarnecidas por duas brácteas foliáceas; 7. Estípulas fimbriadas; 8. Cálice com quatro sépalas, anteras elipsoides, disco nectarífero proeminente; 9. Fruto cápsula septicida turbinada. 10-13. Borreria latifolia (Z.V. Pereira \& G. Lobtchenko 347, Z.V. Pereira et al. 659). 10. Aspecto geral do ramo e folhas; 11. Estípulas fimbriadas; 12. Fruto cápsula septicida obovada pubescente. 13-17. Borreria verticillata (Z.V. Pereira et al. 299). 13. Inflorescência em cimeiras glomeriformes guarnecidas por brácteas foliáceas; 14. Estípulas fimbriadas; 15. Cálice com duas sépalas, corola infundibuliforme, estames exsertos, estigma levemente bilobado; 16. Fruto cápsula septicida subglobosa; 17. Semente.

Figures 2-17. Rubiaceae species of Parque Estadual das Várzeas do Rio Ivinhema, Mato Grosso do Sul State, Brazil. 2. Alibertia edulis (Z.V. Pereira et al. 926), branches with entire, triangular stipules with acuminate apex. 3-5. Alibertia sessilis (Z.V. Pereira et al. 1483, 1486). 3. Entire, triangular stipules with acuminate apex; 4. Tubular corolla with obtuse lobes; 5. Baccate fruit. 6-9. Borreria flavovirens (Z.V. Pereira et al. 615). 6. Branches and glomeriform, cymose inflorescences, with two foliaceous bracts; 7. Fimbriate stipules; 8. Calyx with four sepals, ellipsoid anthers, prominent nectary; 9. Turbinate, septicidal capsule fruit. 10-13. Borreria latifolia (Z.V. Pereira \& G. Lobtchenko 347, Z.V. Pereira et al. 659). 10. General appearance of the branches and leaves; 11. Fimbriate stipules; 12. Obovate, pubescent, septicidal capsule fruit. 13-17. Borreria verticillata (Z.V. Pereira et al. 299). 13. Glomeriform, cymose inflorescence, with foliaceous bracts; 14. Fimbriate stipules; 15. Calyx with two sepals, infundibuliform corolla, exserted stamens, slightly bilobed stigma; 16. Subglobose, septicidal capsule fruit; 17. Seed. 
Material examinado: BRASIL. Mato Grosso do Sul: Parque Estadual das Várzeas do Rio Ivinhema, 9-III-2005, fl., Z.V. Pereira et al. 1081 (DDMS); idem, 28-V-2004, fl., Z.V. Pereira et al. 556 (DDMS); idem, 11-VI-2004, fl., fr., Z.V. Pereira et al. 615 (DDMS); idem, 14-VIII-2004, fr., Z.V. Pereira et al. 702 (DDMS); idem, 13-XI-2004, fl., fr., Z.V. Pereira et al. 902 (DDMS); idem, 13-XI-2004, fl., Z.V. Pereira et al. 930 (DDMS).

Material adicional examinado: BRASIL. BELO Horizonte: Jaboticatubas, 21 -III-1940, fl., $M$. Barreto 10731 (UB). Mato Grosso: Base-Campo, 11-XII-1967, fl., D. Philcox et al. 3462 (UB); Xavantina, 16-XI-1967, fl., D. Philcox et al. 3068 (UB). São Paulo: São Paulo, 14-II-1947, fl., $W$. Hoehne 1502 (UB). Rio De JANEIRO: Rio de Janeiro, 18-VII-1980, fl., A.S. Leão 45 (UB).

Borreria flavovirens distribui-se pelo Brasil, Paraguai e Argentina, no Brasil é encontrada nos Estados de Rondônia, Minas Gerias, Rio de Janeiro, São Paulo, Paraná e Santa Catarina (Bacigalupo \& Cabral 2007). No PEVRI, é encontrada preferencialmente nas bordas dos fragmentos florestais, sendo a primeira ocorrência registrada para o Estado do Mato Grosso do Sul. Essa espécie é vegetativamente muito semelhante a $B$. latifolia, contudo distingue-se desta pelo hábito escandente, folhas verde-amareladas, mesmo nos materiais secos, inflorescência multiflora, sépalas lanceoladas com mais de $3 \mathrm{~mm}$ compr., e sementes com superfície dorsal lisa. No PEVRI, floresce e frutifica praticamente o ano todo.

2.2. Borreria latifolia (Aub1.) K. Schum., Flora Brasiliensis 6(6): 61. 1888 E Spermacoce latifolia Aubl. Histoire des Plantes de la Guyane Française 1: 55-57. 1775.

Figuras 10-12

Ervas anuais, eretas, $30-50 \mathrm{~cm}$ alt. Ramos novos tetragonais, hirsutos. Folhas sésseis ou subsésseis, opostas; lâmina elíptico-ovada, 2-4 × 1-2 cm, hirsuta, nervuras primária e secundárias proeminentes na face adaxial, ápice agudo, base atenuada, margem inteira; estípulas 5-8-fimbriadas, pubescentes. Inflorescências sésseis, em cimeiras glomeriformes, axilares, 3-7-floras; duas brácteas foliáceas; flores sésseis; cálice com 4 sépalas iguais, triangulares, 2-3,5 mm compr., pubescentes; corola infundibuliforme, branca ou azulada, 3-4,5 mm compr., glabra, lobos ovais, 1-2 mm compr., ciliados; estames exsertos, inseridos na fauce da corola; anteras elípticas, subsésseis; ovário bilocular, um óvulo por lóculo; disco nectarífero bipartido; estilete cilíndrico, exserto, 5-7 mm compr.; estigma bífido. Fruto cápsula septicida, obovada, 2-4 × 1,5-3 mm, pubescente, cálice persistente; sementes plano-convexas, elípticas, superfície dorsal fortemente convexa, reticulada, superfície ventral com profundo sulco longitudinal.

Material examinado: BRASIL. MAto Grosso DO Sul: Parque Estadual das Várzeas do Rio Ivinhema, 24-XII-2003, fl., Z.V. Pereira \& G. Lobtchenko 347 (DDMS); idem, 12-VI-2004, fr., Z.V. Pereira et al. 659 (DDMS); idem, 1-X-2005, fl., Z.V. Pereira et al. 1514 (DDMS); idem, 9-II-2005, fl., fr., Z.V. Pereira et al. 1009 (DDMS); idem, 13-XI-2004, fl., fr., Z.V. Pereira et al. 933 (DDMS).

Material adicional examinado: BRASIL. GoIÁs: Serra Dourada, 11-VI-1973, fl., W.R. Anderson 10111 (UB); Serra Dourada, 7-II-1980, fl., J.H. Kirkbride Jr. 3293 (UB); Luziânia, 29-I-1979, fl., E.P. Heringer 17250 (UB); Colina, 8-III-1982, fl., fr., A. Krapovickas et al. 37915 (UB); Araguaina, 15-V-1974, fl., J.A. Rizzo 9879 (UB).

Borreria latifolia ocorre no México, Antilhas e América do Sul (Burger \& Taylor 1993). No Brasil, distribui-se por praticamente todos os Estados (Delprete et al. 2005, Bacigalupo \& Cabral 2007). No PEVRI, B. latifolia está representada por muitos indivíduos, encontrados próximos às estradas e os aceiros. Diferencia-se das demais do gênero pelas folhas hirsutas, inflorescências em glomérulos axilares, 3-7-floros e sementes com a superfície dorsal reticulada. Floresce e frutifica praticamente o ano todo.

2.3. Borreria verticillata (L.) G. Mey., Primitiae Florae Essequeboensis: 83. 1818 三 Spermacoce verticillata L., Species Plantarum 1: 102. 1753. Figuras 13-17

Ervas perenes, eretas, 20-30 cm alt. Ramos subcilíndricos a tetragonais, densamente ramificados, seríceos. Folhas sésseis, opostas; lâmina lanceolada, 3,5-5,5 × 0,5-1 cm, seríceas, nervura primária proeminente na face adaxial, ápice agudo, base atenuada, margem inteira; estípulas 5-6 fimbriadas. Inflorescências sésseis, em cimeiras glomeriformes, terminais e axilares, mais que 15 flores; 4 a 6 brácteas foliáceas iguais; flores sésseis; cálice com 2 sépalas, 1-3 mm compr., lobos lineares, pubescentes, com dentes hialinos entre eles; corola infundibuliforme, branca, 
4-7 mm compr., externamente glabra, internamente com anel de tricomas na metade do tubo, lobos com o ápice sub-recurvado de comprimento igual ao do tubo; estames inseridos na fauce da corola, exsertos; filetes subcilíndricos, 1,5-1,8 mm compr.; anteras lineares; ovário bilocular, um óvulo por lóculo; disco nectarífero bipartido; estilete cilíndrico, 4-8 mm compr., exserto; estigma capitado, levemente bilobado. Fruto cápsula septicida, subglobosa, 1,5-2,3 × 1-1,5 mm, cálice persistente; sementes plano-convexas, subelipsóides, superfície dorsal fortemente convexa, reticulada, superfície ventral escavada, com sulco longitudinal coberto pelo estrofiolo escuro com excrescências glanduloso-esbranquiçadas.

Material examinado: BRASIL. Mato Grosso do Sul: Parque Estadual das Várzeas do Rio Ivinhema, 24-XII-2003, fl., Z.V. Pereira \& G. Lobtchenko 366 (DDMS); idem, 6-IX-2003, fl., fr., Z.V. Pereira et al. 299 (DDMS); idem, 6-IX-2003, fl., fr., Z.V. Pereira et al. 269 (DDMS); idem, 24-XII-2003, fl., fr., Z.V. Pereira \& G. Lobtchenko 348 (DDMS).

Material adicional examinado: BRASIL. GoIÁs: Chapada dos Veadeiros, 23-III-1971, fl., H.S. Irwin et al. s.n. (UB). Mato Grosso do Sul: Estrada 163 Campo Grande-Dourados, 23-X-2001, fl., A. Sciamarelli et al. 1124 (CGMS). Minas Gerais: Serra do Espinhaço, 18-III-1970, fl., H.S. Irwin et al. s.n. (UB); Rio Pandeiros, 21-IV-1973, fl., W.R. Anderson 9276 (UB).

Borreria verticillata distribui-se desde o Sul dos Estados Unidos até a parte meridional da América do Sul, Antilhas e Velho Mundo (Burger \& Taylor 1993). Ocorre preferencialmente em campos, áreas abandonadas e culturas perenes (Kissmann \& Groth 2000). No Brasil, tem ampla distribuição, ocorrendo na maioria dos Estados (Dimitri 1959, Andersson 1992). No PEVRI, esta espécie também é muito comum, abundante em número de indivíduos e amplamente distribuída, ocorrendo principalmente nas margens das estradas e aceiros. Pode ser reconhecida pelas estípulas 5-6-fimbriadas, inflorescência em glomérulos terminais e axilares, multifloros, envolvidos por quatro ou mais brácteas foliáceas iguais, cálice com duas sépalas intercaladas com dentes hialinos, estilete e estames exsertos e sementes com sulco longitudinal coberto pelo estrofíolo escuro, com excrescências glandulares esbranquiçadas. Floresce e frutifica praticamente o ano todo.
3. Cephalanthus L., Species Plantarum 1: 95. 1753.

Cephalanthus apresenta cerca de seis espécies distribuídas nas regiões tropicais e temperadas da América, África e Ásia (Delprete et al. 2004). No Brasil, ocorre somente uma espécie distribuída nos Estados do Mato Grosso do Sul, Paraná, Santa Catarina e Rio Grande do Sul (Andersson 1992, Delprete et al. 2004). No PEVRI, distribui-se pelas áreas de várzeas. As plantas desse gênero caracterizam-se pelas folhas verticiladas, inflorescências em cimeiras glomeriformes terminais, bractéolas paleáceas, flores sésseis, tetrâmeras, frutos drupáceos com sementes cilíndricas, pêndulas, ocupando todo o lóculo.

3.1. Cephalanthus glabratus (Spreng.) K. Schum., Flora Brasiliensis 6(6): 128.1888 =Buddlejaglabrata Spreng.,_Systema Vegetabilium, editio decima sexta 1: 431.1825.

Figuras $18-22$

Arbustos, 1,5 m alt. Ramos cilíndricos, glabros. Folhas verticiladas, pecioladas, pecíolo semicilíndrico, glabros, 3-4 mm compr.; lâmina lanceolada, 2,5-6,5 × 1-2,5 cm, glabras, nervura primária proeminente em ambas as faces, 4-6 nervuras secundárias de cada lado, ápice acuminado, base assimétrica, margem inteira; estípulas persistentes, inteiras, triangulares, ápice acuminado. Inflorescências pedunculadas, pedúnculos $3-4,5 \mathrm{~cm}$ compr., em cimeira glomeriformes, terminais; brácteas foliáceas, bractéolas filiformes, paleáceas, ápice arredondado; flores sésseis; cálice tubuloso, $3 \mathrm{~mm}$ compr., lobos triangulares, internamente piloso; corola infundibuliforme, branca, 3-5 mm compr., externamente glabra, internamente pilosa, lobos obtusos, 2-2,5 mm compr.; estames inseridos na fauce da corola, inclusos; filetes semicilíndricos, $1 \mathrm{~mm}$ compr., anteras lanceoladas; ovário bilocular, um óvulo por lóculo; disco nectarífero bipartido, $1 \mathrm{~mm}$ compr., estilete cilíndrico, exserto, 5-7 mm compr., estigma clavado. Fruto drupáceo, 3-5 × 1,5-2,5 mm, cálice persistente; sementes obovadas.

Material examinado: BRASIL. Mato Grosso Do Sul: Parque Estadual das Várzeas do Rio Ivinhema, 6-IX-2003, fr., Z.V. Pereira et al. 281 (DDMS); idem, 11-IX-2004, fl., Z.V. Pereira et al. 777 (DDMS); idem, 21-IV-2005, fl., Z.V. Pereira et al. 1222 (DDMS); idem, 12-X-2006, fr., Z.V. Pereira et al. 1668 (DDMS).

Material adicional examinado: BRASIL. Mato Grosso Do SuL: Anaurilândia, 15-X-1998, fl., A. Amaral Jr. et al. 
235 (CGMS); Miranda, 7-IX-1990, fl., L.R.H. Bicudo et al. 265 (CGMS); Três Lagoas, 20-IX-1964, fl., J.C. Gomes Jr. 2201 (UB); Anaurilândia, 17-X-1998, fl., A. Amaral Jr. et al. 277 (VIC).

Cephalanthus glabratus distribui-se no Brasil, Argentina, Paraguai e Uruguai (Andersson 1992). No Brasil, ocorre nos Estados do Mato Grosso do Sul, Santa Catarina e Rio Grande do Sul (Anderssom 1992, Delprete et al. 2004). No PEVRI, ocorrem poucos indivíduos distribuídos nas áreas de várzeas. Das espécies amostradas no PEVRI, $C$. glabratus é a única que apresenta folhas verticiladas com inflorescências pedunculadas em cimeiras glomeriformes. Floresce e frutifica de outubro a janeiro.

\section{Chomelia Jacquin, Enumeratio Systematica} Plantarum: 1. 1760.

Este gênero compreende cerca de 400 espécies distribuídas nas regiões tropicais da África, Ásia e América Central até o Sul do Brasil (Dwyer 1980, Delprete et al. 2004). No Brasil, distribui-se por todo o território nacional (Andersson 1992, Barbosa 2007). No PEVRI, está representada por duas espécies distribuídas nas matas ciliares e áreas de transição entre a floresta estacional semidecidual e o cerrado.

No PEVRI, as espécies de Chomelia assemelham-se às de Randia e Guettarda, contudo as inflorescências pedunculadas ou subsésseis, em cimeiras uni- pauciou multifloras, flores pediceladas, tetrâmeras, cálice com quatro lobos iguais ou desiguais, ovário bilolurar, um óvulo pêndulo no ápice de cada lóculo, estigma bífido e sementes cilíndricas, pêndulas, ocupando todo o lóculo, constituem caracteres diagnósticos importantes.

Chave para identificação das espécies de Chomelia no PEVRI

1. Lâmina foliar com mais de 3,5 cm compr.; nervuras secundárias 4-8 de cada lado; cálice com lobos desiguais 1. C. brasiliana

1. Lâmina foliar de 1,5-3,5 cm compr.; nervuras secundárias 3-4 de cada lado; cálice com lobos iguais 2. C. obtusa

4.1. Chomelia brasiliana A. Rich., Mémoires de la Société d'Histoire Naturelle de Paris 5: 183. 1834. Figuras 23-25

Arvoretas, 1-2 m alt. Ramos cilíndricos, glabros, dois espinhos por nó. Folhas agrupadas no ápice do ramo, pecioladas, pecíolo semicilíndrico, 7-9 mm compr., pubescente; lâmina lanceoladas, $3,5-8 \times 2-3,5 \mathrm{~cm}$, pubescente sobre as nervuras, nervura primária e secundárias proeminentes na face abaxial, 4-8 nervuras secundárias de cada lado, ápice agudo, base aguda, margem inteira; estípulas inteiras, persistentes, triangulares, ápice acuminado. Inflorescências curto-pedunculadas, em cimeiras 1-4-floras, axilares; bractéolas lanceoladas, reduzidas; flores curto pediceladas, pedicelo 2-6 mm compr.; cálice com quatro sépalas, 5-9 mm compr., lobos desiguais, lineares, 2-4 mm compr., com coleteres na base da face inferior; corola hipocrateriforme, branca, 5-12 mm compr., externamente serícea, internamente glabra, lobos lanceolados, 2-4 mm compr.; estames inseridos no tubo da corola, filetes semicilíndricos, 0,5-2 mm compr.; anteras lanceoladas; ovário bilocular, um óvulo por lóculo; disco nectarífero inteiro; estilete cilíndrico, exserto, 4-13 mm compr., estigma bífido. Fruto drupáceo, alongado, recurvado, 5-10 × 10-30 mm, cálice persistente, sementes cilíndricas, pêndulas, ocupando todo o lóculo.

Material examinado: BRASIL. Mato Grosso Do Sul: Parque Estadual das Várzeas do Rio Ivinhema, 6-IX-2003, fl., fr., Z.V. Pereira et al. 234 (DDMS).

Material adicional examinado: BRASIL. PARANÁ: Antonina, 26-IX-1961, fl., G. Hastschach 8280 (UFG). Guaratuba, 17-IX-1999, fl. E.P. Santos et al. 808 (UFG). Santa Catarina: Joinville, 17-X-1987, $\mathrm{fl}$, D.B. Falkenberg 4486 (UFG). Rio de JANEIRO: Niterói, 12-II-1985, fl., fr., T. Plowman et al. 13925 (UFG).

Chomelia brasiliana distribui-se desde o Estado da Bahia, Mato Grosso, Goiás, Minas Gerais até o Estado do Rio Grande do Sul (Andersson 1992, Delprete et al. 2004). No PEVRI, foi amostrado apenas um indivíduo encontrado na mata ciliar da margem direita do Rio Ivinhema, sendo a primeira ocorrência registrada para o Estado do Mato Grosso do Sul. Esta espécie difere de C. obtusa pelas folhas com mais de 3,5 cm compr., 4-8 nervuras secundárias de cada lado, inflorescência em cimeiras de uma a quatro flores, cálice com lobos desiguais e fruto alongado e recurvado. Floresce de setembro a novembro, frutifica de novembro a abril.

4.2. Chomelia obtusa Cham. \& Schltdl., Linnaea 4: 185. 1829.

Figuras 26-28

Arvoretas, ca. $2 \mathrm{~m}$ alt. Ramos cilíndricos, glabros, lenticelados, dois espinhos por nó. Folhas 
pecioladas, pecíolo semicilíndrico, 1-3 mm compr.; lâmina elíptica, 1,5-3,5 × 0,5-2 cm, glabra, nervura primária proeminente em ambas as faces, nervuras secundárias 3-4 de cada lado, ápice obtuso, base obtusa, margem inteira; estípulas inteiras, persistentes, triangulares, ápice acuminado, pilosas. Inflorescências pedunculadas, em cimeiras unifloras, raramente bifloras, axilares; brácteas ovais reduzidas; flores pediceladas, pedicelo 6-12 mm compr.; cálice com quatro sépalas, 3-4 mm compr., lobos iguais, obtusos, 1-1,5 mm compr., com coleteres na base da face inferior; corola hipocrateriforme, vinácea, 1-1,5 cm compr., glabra, lobos arredondados, 1-2 mm compr.; estames inseridos um pouco abaixo do ápice da fauce da corola, inclusos, filetes semicilíndricos, 0,5-1 mm compr.; anteras, lanceoladas; ovário bilocular, um óvulo por lóculo; disco nectarífero inteiro, 0,2-0,4 mm compr.; estilete cilíndrico, exserto, 7-9 mm compr., estigma bífido. Fruto drupáceo, elipsóide, 7-12 × 3-4,5 mm, cálice persistente, sementes cilíndricas, pêndulas, ocupando todo o lóculo.

Material examinado: BRASIL. Mato Grosso do Sul: Parque Estadual das Várzeas do Rio Ivinhema, 13-VII-2005, fl., fr., Z.V. Pereira et al. 1385 (DDMS).

Material adicional examinado: BRASIL. BAHIA: Ponte Pedra do Cavalo, 14-IV-1977, fl., E.F. Gusmão 458 (UB). Goí́s: Chapada dos Veadeiros, 19-III-1973, fr., W.R. Anderson 7484 (UB); Chapadas dos Veadeiros, 13-III-1969, fl., fr., H.S. Irwin s.n. (UB); Serra do Caiapó, 30-IV-1973, fl., fr., W.R. Anderson 9470 (UB). Mato Grosso: Fazenda São Vicente do Rio Claro, 3-X-1986, fl., fr., J.A. Ratter et al. 5244 (UB); Serra do Roncador, 6-VI-1966, fr., fl., H.S. Irwin s.n. (UB).

Chomelia obtusa tem distribuição neotropical (Andersson 1992). No Brasil, é encontrada nos Estados da Paraíba (Pereira \& Barbosa 2004) e de Minas Gerais até o Rio Grande do Sul (Delprete et al. 2004). No PEVRI, foi encontrado um único indivíduo na área de transição entra a Floresta Estacional Semidecidual e o Cerrado. Caracteriza-se pelos dois espinhos por nó, folhas pequenas, elípticas, inflorescência pedunculada em cimeiras unifloras, flores tetrâmeras, cálice com quatro lobos iguais, corola vinácea, 1-1,5 cm de comprimento, estames inclusos e estigma bífido. Floresce e frutifica de julho a dezembro.

5. Coccocypselum P. Browne, Civ. Nat. Hist. Jamaica: 144. 1756.

Coccocypselum compreende cerca de 35 espécies amplamente distribuídas na região neotropical, ocorrendo no México, na Colômbia, no Brasil, nas regiões Centro-Oeste, Sudeste e Sul, e estendendo-se até a Argentina (Andersson 1992, Costa 2005). No Brasil, encontra-se a maior diversidade do gênero, com cerca de 20 espécies, notadamente na Mata Atlântica (Andersson 1992, Costa 2005, Costa \& Mamede 2007). No PEVRI, este gênero está representado por duas espécies, distribuídas nos fragmentos de transição e na mata paludícola.

Os representantes deste gênero caracterizam-se, principalmente, pelo hábito herbáceo, estípulas subuladas ou filiformes, inflorescências em glomérulos terminais ou axilares, sésseis ou pedunculados, flores distílicas, tetrâmeras, ovário bilocular, pluriovulado e frutos maduros azuis ou purpúreos, polispérmicos. A presença de pedúnculo nas inflorescências tem sido uma das características mais empregadas para a distinção das espécies deste gênero (Dwyer 1980, Burger \& Taylor 1993, Pereira et al. 2006a). Schumann (1888) separou as espécies brasileiras de Coccocypselum, baseado, principalmente, na morfologia da inflorescência, forma e tamanho dos lobos do cálice.

Chave para identificação das espécies de Coccocypselum no PEVRI

1. Lâmina foliar hirsuta; inflorescências com

6-8 flores; pedúnculo 4-6 cm compr. ... 1. C. condalia

1. Lâmina foliar velutina; inflorescências com

10-12 flores; pedúnculo 2-8 mm compr. 2. C. lanceolatum

5.1. Coccocypselum condalia Persoon, Syn. Pl. 1: 132,1805

Figuras 29-31

Ervas perenes, prostradas. Ramos cilíndricos, esparsamente hirsutos. Folhas pecioladas, pecíolo semicilíndrico 0,7-1 cm compr., hirsuto; lâmina oval-lancelada, 3-7 × 1,5-3 cm, hirsuta, nervuras primárias e secundárias proeminentes na face abaxial, 6-7 nervuras secundárias de cada lado, ápice agudo, base variando de truncada a oblíqua, margem inteira; estípulas filiformes. Inflorescências pedunculadas, pedúnculos 4-6 cm compr., cimeiras glomeriformes, axilares, 6-8 flores, hirsutas, brácteas foliáceas 1,5-2 mm compr.; flores sésseis, 4-meras, distílicas; cálice 4-5 mm compr., lobos lanceolados, 3-4 mm compr., eretos, hirsutos; corola infundibuliforme, esbranquiçada no terço basal e lilás no terço superior, 10-15 mm compr., pilosa no terço apical, internamente 

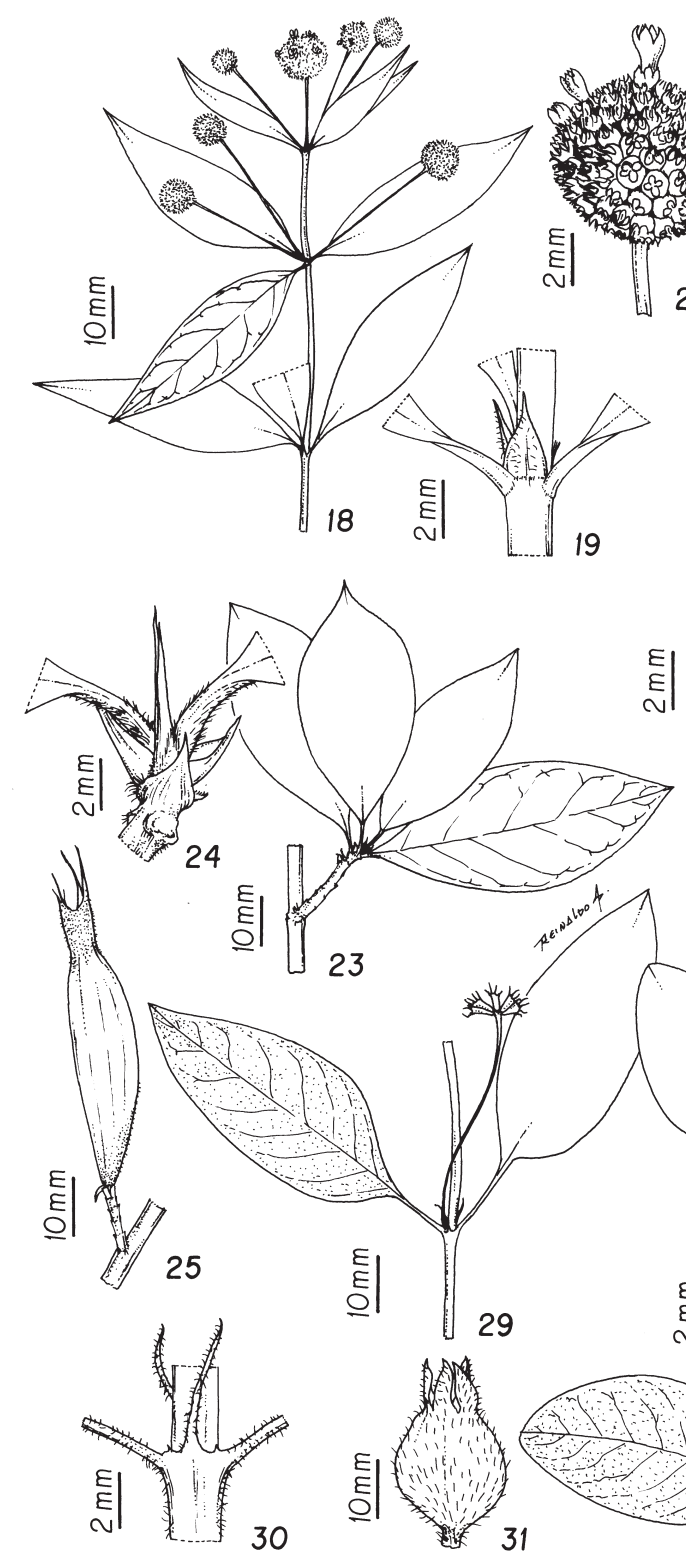

19
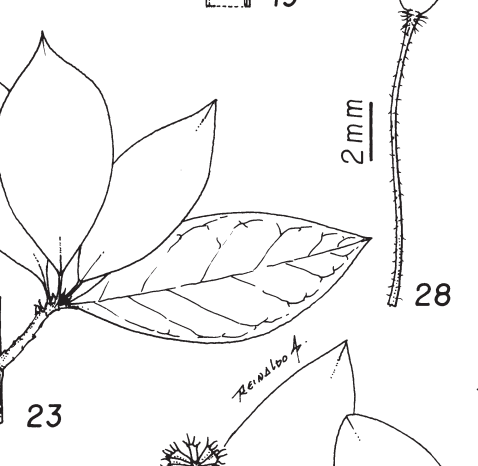

हl
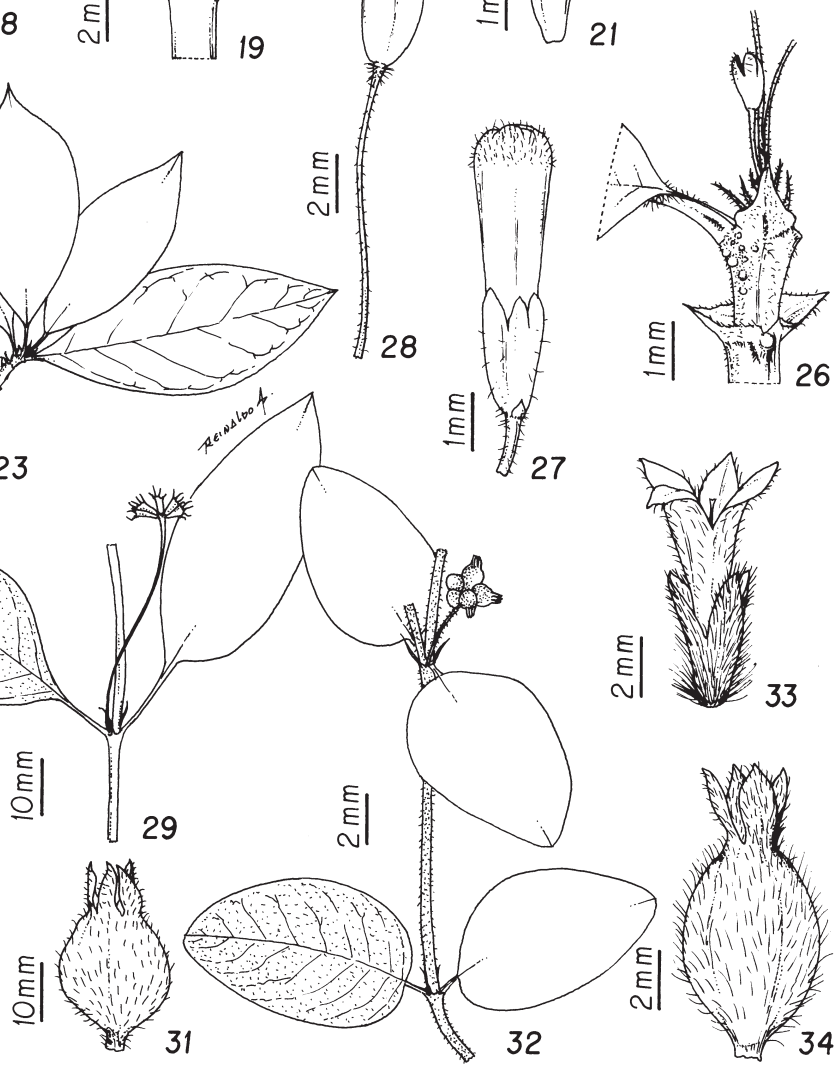

33

Figuras 18-34. Espécies de Rubiaceae do Parque Estadual das Várzeas do Rio Ivinhema, MS, Brasil. 18-22. Cephalanthus glabratus (Z.V. Pereira et al. 281, 777). 18. Folhas verticiladas, inflorescências terminais, pedunculadas. 19. Estípulas inteiras com ápice acuminado. 20. Detalhe da inflorescência em cimeiras glomeriformes. 21. Cálice internamente com tricomas, corola infundibuliforme, estigma clavado. 22. Fruto drupáceo. 23-25. Chomelia brasiliana (Z.V. Pereira et al. 234). 23. Detalhe das folhas agrupadas no ápice do ramo. 24. Estípulas inteiras com ápice acuminado e espinhos. 25. Frutos drupáceo alongado. 26-28. Chomelia obtusa (Z.V. Pereira et al. 1385). 26. Estípulas inteiras com ápice acuminado, inflorescência uniflora pedunculada. 27. Botão floral. 28. Fruto drupáceo elipsoide. 29-31. Coccocypselum condalia (Z.V. Pereira et al. 810, 1155). 29. Inflorescência axilar, pendunculada. 30. Estípulas filiformes; 31 . Fruto bacáceo elipsoide. 32-34. Coccocypselum lanceolatum (Z.V. Pereira et al. 636, 766). 32. Folhas oval-lanceoladas, estípulas filiformes. 33. Corola infundibuliforme, velutina. 34. Fruto bacáceo elipsóide, velutino.

Figures 18-34. Rubiaceae species of Parque Estadual das Várzeas do Rio Ivinhema, Mato Grosso do Sul State, Brazil. 18-22. Cephalanthus glabratus (Z.V. Pereira et al. 281, 777). 18. Verticilate leaves, terminal, pedunculate inflorescences. 19. Entire stipules, with acuminate apex. 20. Detail of glomeriform, cymose inflorescence. 21. Calyx with internal trichomes, infundibuliform corolla, clavate stigma; 22. Drupaceous fruit. 23-25. Chomelia brasiliana (Z.V. Pereira et al. 234). 23. Detail of leaves grouped at the branch apex. 24. Entire stipules, acuminate apex, and thorns. 25. Drupaceous, elongated fruits. 26-28. Chomelia obtusa (Z.V. Pereira et al. 1385). 26. Entire stipules, acuminate apex, pedunculate, unifloral inflorescence. 27. Flower bud. 28. Ellipsoid, drupaceous fruit. 29-31. Coccocypselum condalia (Z.V. Pereira et al. 810, 1155). 29. Axillary, pedunculate inflorescence. 30. Filiform stipules. 31. Baccate, ellipsoidal fruits; 32-34. Coccocypselum lanceolatum (Z.V. Pereira et al. 636, 766). 32. Oval-lanceolate leaves, filiform stipules. 33. Infundibuliform, velutinous corolla. 34. Baccate, ellipsoidal, velutinous fruits. 
pilosa na região mediana, lobos triangulares 4-5 mm compr.; estames inseridos na fauce ou no tubo da corola, inclusos ou exsertos; filetes semicilíndricos, 3-10 mm compr.; anteras lanceoladas; ovário bilocular, pluriovulado; disco nectarífero inteiro; estilete cilíndrico, inclusos ou exsertos, 6-10 mm compr; estigma bífido. Fruto bacáceo, azul, elipsóide, 2-3 $\times 1-3 \mathrm{~cm}$, cálice persistente; sementes orbiculares, plano convexas, castanhas, superfície dorsal muricada, superfície ventral com sulco longitudinal, de 2-3 mm compr.

Material examinado: BRASIL. Mato Grosso do Sul: Parque Estadual das Várzeas do Rio Ivinhema, 15-VIII-2003, fr., Z.V. Pereira et al. 762 (DDMS); idem, 11-IX-2004, fr., Z.V. Pereira et al. 810 (DDMS); idem, 13-III-2005, fl., Z.V. Pereira et al. 1155 (DDMS); idem, 13-VII-2005, fr., Z.V. Pereira et al. 1349 (DDMS); idem, 15-VII-2005, fl., Z.V. Pereira et al. 1450 (DDMS).

Material adicional examinado: BRASIL. GoIÁs: Porto Nacional, 13-VI-1974, fl., fr., J.A. Rizzo 9899 (UB); Porto Nacional, 8-XI-1973, fl., J.A. Rizzo 9395 (UB). Minas Gerais: Carangola, 27-III-1935, fl., J.Y. Kuchlmann 34 (VIC); Serra do Cipó, 13-IX-1986, fl., H.C. Morais s.n. (VIC). São Paulo: São Paulo, 2-II-1932, fr., M. Kuhlmann s.n. (UB); Piruibe, 6-X-1983, fl., N. Figueiredo et al. s.n. (UB).

Coccocypselum condalia distribui-se do México, América Central até América do Sul (Anderson 1992). No Brasil, ocorre em diversas formações da Mata Atlântica da Bahia até o Sul do país, além de ocorrer nos Estados do Mato Grosso e Mato Grosso do Sul (Costa 2005). No PEVRI, foram amostrados vários indivíduos distribuídos na mata paludícola, sempre em locais bastante úmidos.

No PEVRI, C. condalia pode ser reconhecida pelas folhas ovais ou lanceoladas, hirsutas, inflorescências pedunculadas, pedúnculos de 4-6 cm compr., cimeiras glomeriformes com 6-8 flores, cálice com lobos eretos, frutos e sementes maiores que em $C$. lanceolatum. Delprete et al. (2004), caracterizaram esta espécie como glabra ou com tricomas curtos nas margens da lâmina foliar, contudo, todos os materiais observados no PEVRI, apresentam indumento hirsuto. Costa (2005), comentou que populações de C. condalia existentes em áreas de restinga no Sudeste do Estado de São Paulo, Leste do Paraná e Santa Catarina e Nordeste do Rio Grande do Sul apresentam indumento hirsuto. Esses dados corroboram com dados de Costa $\&$ Mamede (2002) que comentaram que a densidade do indumento pode ser um caráter bastante variável numa mesma espécie deste gênero. No PEVRI, floresce e frutifica de setembro a agosto.

5.2. Coccocypselum lanceolatum (Ruiz \& Pav.) Pers., Syn. Pl. 1: 132. 1805 三 Condalia lanceolata Ruiz \& Pav., P1. F1. Peruv. 1: 54. 1798.

Figuras 32-34

Ervas perenes, prostradas. Ramos cilíndricos, velutinos. Folhas pecioladas, pecíolo semicilíndrico, 0,8-1,5 cm compr., velutino; lâmina oval-lanceolada, 1-4 $\times 1-3 \mathrm{~cm}$, velutina, nervuras primária e secundárias proeminentes na face abaxial, 7-12 nervuras secundárias de cada lado, ápice agudo a obtuso, base obtusa, margem inteira; estípulas filiformes. Inflorescências pedunculadas, pedúnculo de 2-8 mm compr., cimeiras glomeriformes terminais e axilares, 10-12 flores, densamente pubescentes; brácteas foliáceas 1-3 mm compr.; flores sésseis, 4-meras, distílicas; cálice 2-6 mm compr., lobos ovais, 1-2 mm compr., reflexos, velutinos; corola infundibuliforme, azulada, 2-6,5 mm compr., velutina, lobos triangulares, 1-2 mm compr.; estames inseridos na fauce ou no tubo da corola, inclusos ou exsertos; filetes semicilíndricos, $1 \mathrm{~mm}$ compr.; anteras lanceoladas; ovário bilocular, pluriovulado; disco nectarífero inteiro; estilete cilíndrico, incluso ou exserto, 2,5 mm compr.; estigma bífido. Fruto bacáceo, elipsóide ou obovóide, azul brilhante, 1-2,5 × 0,6-1,5 cm, cálice persistente, sementes orbiculares, plano-convexas, castanhas, superfície dorsal muricada, superfície ventral com sulco longitudinal, $1 \mathrm{~mm}$ compr.

Material examinado: BRASIL. Mato Grosso do Sul: Parque Estadual das Várzeas do Rio Ivinhema, 10-VI-2004, fr., Z.V. Pereira et al. 636 (DDMS); idem, 15-VIII-2003, fl., Z.V. Pereira et al. 766 (DDMS); idem, 6-IX-2003, fl., Z.V. Pereira et al. 298 (DDMS); idem, 5-II-2005, fl., fr., Z.V. Pereira et al. 1000 (DDMS); idem, 6-VII-2005, fr., Z.V. Pereira et al. 1458 (DDMS).

Material adicional examinado: BRASIL. BAHIA: Abaíra, 19-XII-1991, fl., E. NicLughadha et al. s.n. (UB). GoIÁs: Goianeira, s.d., fl., J.A. Rizzo 5741 (UB); Pireneus, 16-I-1972, fl., fr., H.S. Irwin et al. s.n. (UB). Mato Grosso do Sul: Campo Grande, 5-IV-1991, fl., Equipe Santa Inês 186 (CGMS). Minas Gerais: Viçosa, 3-IV-1984, fl., fr., L.S. Moura 536 (VIC).

Coccocypselum lanceolatum apresenta ampla distribuição na região neotropical, ocorrendo desde 
o Sul do México até a Argentina, exceto na Região Amazônica (Dwyer 1980, Andersson 1992). No Brasil, encontra-se nas Regiões Sudeste, Centro Oeste e Sul (Smith \& Downs 1956, Costa 2005). No PEVRI, ocorrem várias populações distribuídas principalmente nos fragmentos de transição próximo a entrada principal do Parque. Caracteriza-se pelas folhas velutinas, inflorescências pedunculadas, pedúnculo com 2-8 mm de comprimento, cimeiras glomeriformes terminais e axilares, 10-12 flores e cálice reflexo. A presença de cálice reflexo tem sido referida por Steyermark $(1967,1974)$ como uma característica importante na delimitação desta espécie. No PEVRI, floresce e frutifica de setembro a fevereiro.

6. Coussarea Aubl., Histoire des Plantes de la Guyane Française 1: 98. 1775.

Coussarea inclui aproximadamente 140 espécies com ampla distribuição na América Tropical (Dwyer 1980, Delprete et al. 2004). No Brasil, encontra-se distribuída em quase todo o território nacional (Pereira 1954, Andersson 1992). No PEVRI, está representada por duas espécies distribuídas nos fragmentos da área de transição próximo a entrada do Parque.

As espécies deste gênero caracterizam-se pelas inflorescências geralmente terminais, flores tetrâmeras, cálice geralmente truncado ou com lobos pouco desenvolvidos, anteras subsésseis, ovário bilocular ou indistintamente unilocular, biovular, fruto monospérmico, elíptico, globoso e semente presa verticalmente na base.

Chave para identificação das espécies de Coussarea no PEVRI

1. Folhas glabras em ambas as faces; corola 10-18 mm compr.; frutos subgloboso, verdeamarelado . 1. C. hydrangeifolia

1. Folhas velutinas na superfície abaxial; corola 49-60 mm compr., fruto globoso, branco 2. C. platyphylla

6.1. Coussarea hydrangeifolia (Benth.) Benth. \& Hook. f., Genera Plantarum 2: 121. $1873 \equiv$ Faramea hydrangeifolia Benth., Linnaea 23: 451. 1850.

Figuras 35-37

Árvore, 4-5 m alt. Ramos cilíndricos, glabros, lenticelados. Folhas curto-pecioladas, pecíolo semicilíndrico, glabro, 0,4-0,7 cm compr.; lâmina elíptica, $10-20 \times 5-15 \mathrm{~cm}$, glabra, nervuras primárias e secundárias proeminentes na face abaxial, 5-6 nervuras secundárias de cada lado, ápice agudo a acuminado, base obtusa, margem inteira; estípulas inteiras, triangulares, ápice agudo, caducas. Inflorescências pedunculadas, pedúnculo $1-2 \mathrm{~cm}$ compr., paniculiformes, terminais; flores curto pediceladas, pedicelos 2-5 mm compr., distílicas; cálice truncado, 3-4 mm compr.; corola tubular, branca 10-18 mm compr., glabra, lobos lanceolados, 4-7 mm compr.; estames inserido no tubo ou na fauce da corola, inclusos ou exsertos; filetes semicilíndricos, 1-3 mm compr.; anteras lanceoladas; ovário unilocular, um óvulo; disco nectarífero inteiro, 1-1,2 mm compr.; estilete cilíndrico, incluso ou exserto, 5-18 mm compr, estigma bífido. Fruto bacáceo, subgloboso, 1,5-2,5 × 1,0-1,5 cm, monospérmico, pericarpo lenticelado, verde amarelado, cálice persistente; semente posicionada verticalmente na base, elipsóide, lisa.

Material examinado: BRASIL. Mato Grosso Do Sul: Parque Estadual das Várzeas do Rio Ivinhema, 10-VI-2004, fr., Z.V. Pereira et al. 603 (DDMS); idem, 15-VII-2005, fl., Z.V. Pereira et al. 1448 (DDMS); Parque Estadual das Várzeas do Rio Ivinhema, 12-X-2006, fl., Z.V. Pereira et al. 1671 (DDMS).

Material adicional examinado: BRASIL. DistrITo Federal: Brasília, 3-VI-1980, fl., fr., E.P. Heringer et al. 4984 (UEC). Goiás: Rodovia Goiás-São Paulo, 1-X-1968, fl., J.A. Rizzo 2348 (UFG); Pequizeiro a Couto Magalhães, 8-IX-1973, fl., J.A. Rizzo 9253 (UFG); Bosque UFG, 5-XII-1978, fr., J.A. Rizzo et al. 10551 (UFG); Silvânia, 12-IX-1998, fr., P. Delprete et al. 6586 (UFG); Serra da Natividade, 8-XII-1973, fl., J.A. Rizzo et al. 9460 (UFG).

Coussarea hydrangeifolia distribui-se pela Bolívia, Paraguai, Peru e Brasil, nos Estados do Amapá, Tocantins, Ceará, Mato Grosso, Mato Grosso do Sul, Goiás, Distrito Federal, Minas Gerais, Rio de Janeiro e São Paulo (Gomes 2003). No PEVRI, foram amostradas várias populações distribuídas nos fragmentos próximos à entrada do parque.

No PEVRI, esta espécie é vegetativamente muito semelhante a $C$. platyphylla, contudo a ausência de tricomas nas folhas, inflorescências curto-pedunculadas, flores pediceladas, com menos de $10 \mathrm{~mm}$ de compr., corola com 10-18 mm de compr. e frutos subglobosos, verde-amarelados, constituem caracteres diagnósticos importantes. Floresce de outubro a dezembro e frutifica de dezembro a julho. 


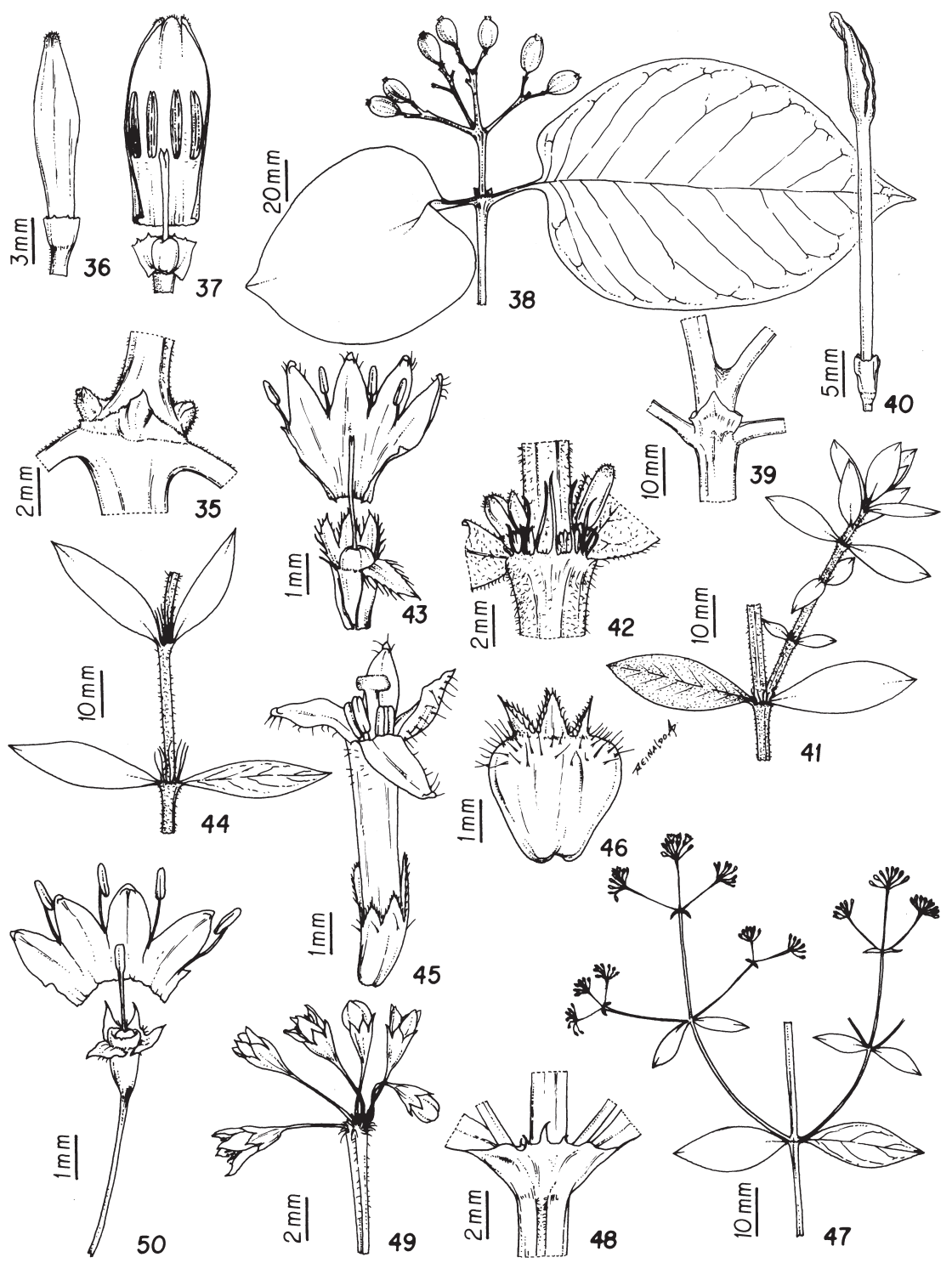

Figuras 35-50. Espécies de Rubiaceae do Parque Estadual das Várzeas do Rio Ivinhema, MS, Brasil. 35-37. Coussarea hydrangeifolia (Z.V. Pereira et al. 1448). 35. Estípulas inteiras, triangulares, ápice agudo. 36. Botão floral. 37. Detalhe da flor aberta. 38-40. Coussarea platyphylla (Z.V. Pereira et al. 401, 289). 38. Detalhe da folha e fruto bacáceo globoso. 39. Estípulas inteiras triangulares com ápice agudo. 40. Botão floral. 41-43. Diodella radula (Z.V. Pereira et al. 950). 41. Detalhe do ramo hirsuto. 42. Estípulas fimbriadas e inflorescência pauciflora. 43. Detalhe da flor aberta evidenciando as sépalas ciliadas e o estigma levemente bilobado. 44-46. Diodella teres (Z.V. Pereira \& G. Lobcthenko 346). 44. Detalhe do ramo e estípulas. 45. Flor evidenciando os estames parcialmente exsertos e o estigma capitado. 46. Fruto esquizocárpico, obovado com pericarpo cerdoso. 47-50. Emmeorhiza umbellata (Z.V. Pereira et al. 751). 47. Inflorescência em cimeiras compostas de umbelas. 48. Detalhe das estípulas fimbriadas. 49. Botões florais e flores. 50. Detalhe da flor aberta evidenciando o cálice com os lobos parcialmente fundido e estames exsertos.

Figures 35-50. Rubiaceae species of Parque Estadual Várzeas do Rio Ivinhema, Mato Grosso do Sul State, Brazil. 35-37. Coussarea hydrangeifolia (Z.V. Pereira et al. 1448). 35. Entire, triangular stipules, acute apex. 36. Flower bud. 37. Detail of open flower. 38-40. Coussarea platyphylla (Z.V. Pereira et al. 401, 289). 38. Detail of leaf and globose, baccate fruit. 39. Entire, triangular stipules, acute apex. 40. Flower bud. 41-43. Diodella radula (Z.V. Pereira et al. 950). 41. Detail of hirsute branch. 42. Fimbriate stipules and pauciflorus inflorescence. 43. Detail of open flower showing ciliate sepals and slightly bilobed stigma. 44-46. Diodella teres (Z.V. Pereira \& G. Lobcthenko 346). 44. Details of branch and stipules. 45. Flower showing partially exserted stamens, and capitate stigma. 46. Obovate, schizocarpous fruit, with setaceous pericarp. 47-50. Emmeorhiza umbellata (Z.V. Pereira et al. 751). 47. Inflorescence composed of cymose umbels. 48. Detail of fimbriate stipules. 49. Flower buds and flower. 50. Detail of open flower showing the calyx with partially fused lobes and exserted stamens. 
6.2. Coussarea platyphylla Mull. Arg., Flora 58: 465. 1875.

Figuras 38-40

Árvore, ca. $6 \mathrm{~m}$ alt. Ramos cilíndricos, glabros, lenticelados. Folhas pecioladas, pecíolo semicilíndrico, glabro, 1-1,5 cm compr.; lâmina elíptica, $12-25 \times 9-15 \mathrm{~cm}$, velutina somente na superfície abaxial, nervuras primárias e secundárias proeminentes na superfície abaxial, 6-7 nervuras secundárias de cada lado, ápice agudo, base obtusa, margem inteira; estípulas inteiras, triangulares, ápice agudo, caducas. Inflorescências pedunculadas, pedúnculo 3-4 cm compr., paniculiformes, terminais; flores sésseis, distílicas; cálice truncado, 6-8 mm compr.; corola tubular, branca 49-60 mm compr., glabra, lobos triangulares 11-14 mm compr.; estames inserido no tubo ou na fauce da corola, inclusos ou exsertos; filetes semicilíndricos, 1-5 mm compr.; anteras lanceoladas; ovário unilocular, um óvulo; disco nectarífero inteiro, 1-1,5 mm compr.; estilete cilíndrico, incluso ou exserto, $28-43,5 \mathrm{~mm}$ compr., estigma bífido. Fruto bacáceo, globoso, 2-3,5 × 1,5-3 cm, monospérmico, pericarpo lenticelado, branco, cálice persistente; semente posicionada verticalmente na base, elipsóide, lisa.

Material examinado: BRASIL. MAto Grosso Do Sul: Parque Estadual das Várzeas do Rio Ivinhema, 27-XII-2003, fr., Z.V. Pereira et al. 401 (DDMS); idem, 6-IX-2003, fl., Z.V. Pereira et al. 289 (DDMS); idem, 27-III-2004, fr., Z.V. Pereira et al. 446 (DDMS); idem, 14-VIII-2004, fr., Z.V. Pereira et al. 705 (DDMS); idem, 5-II-2005, fr., Z.V. Pereira et al. 997 (DDMS).

Material adicional examinado: BRASIL. Mato Grosso: Chapada dos Guimarães, 27-V-1984, fl., fr., J.R.B. Monteiro et al. 56 (UEC); Chapada dos Guimarães, 21-II-1997, fr., A.G. Nave et al. 1154 (UEC); Chapada dos Guimarães, 24-II-1997, fr., A.G. Nave et al. 1220 (UEC). Mato Grosso do Sul: Margem do Rio Paraná, 16-X-1998, fl., L.R. Bicudo et al. 211 (CGMS); Campo Grande, 4-IX-1998, fr., E.L. Vargas s.n. (CGMS).

Coussarea platyphylla tem distribuição neotropical (Andersson 1992). No Brasil, ocorre nos Estados de Goiás, Mato Grosso, Mato Grosso do Sul e do interior da Bahia até o Rio Grande do Sul (Andersson 1992). No PEVRI, está representada por vários indivíduos distribuídos nos fragmentos próximos a entrada do Parque. Essa espécie é de fácil reconhecimento pelas folhas grandes, velutinas na superfície abaxial, inflorescência pedunculada, flores sésseis, grandes, cálice truncado, e frutos monospérmicos com pericarpo lenticelados e brancos. No PEVRI, floresce de setembro a dezembro e frutifica de novembro a julho.

7. Diodella Small, Flora of Miami: 177. 1913.

Diodella esta representado por 10 espécies distribuídas da América do Norte até a América do Sul (Delprete et al. 2004). No Brasil, distribui-se por quase todo o território nacional (Bacigalupo \& Cabral 1999). No PEVRI, ocorrem duas espécies amplamente distribuídas por todo o Parque.

As espécies desse gênero caracterizam-se pelo hábito herbáceo, folhas sésseis ou subsésseis, estípulas fimbriadas, inflorescências axilares, em cimeiras glomeriformes, ou ainda flores solitárias, cálice com 2 ou 4 sépalas iguais ou desiguais e o fruto esquizocárpico que se divide em dois mericarpos indeiscentes.

Embora alguns autores tratem as espécies de Diodia, Borreria e Spermacoce sob o gênero Spermacoce, Bacigalupo \& Cabral (1999) consideraram os referidos gêneros distintos e caracterizam Diodella pelo fruto esquizocárpico com dois mericarpos indeiscentes, hábito rasteiro, estípulas quase sempre bem desenvolvidas, inflorescências paucifloras, axilares, flores semi-ocultas pela bainha estipular, homostílicas, corola infundibuliforme, lobos pilosos na superfície interna, e estames e estilete exsertos. Além desses, segundo Delprete et al. (2004), o estigma capitado ou curto-lobado e a face ventral da semente com depressão e com duas extensões apicais em forma de "Y" constituem caracteres diagnósticos importantes.

Chave para identificação das espécies de Diodella no PEVRI

1. Lâmina foliar lanceolada; nervuras secundárias proeminentes na superfície abaxial; inflorescência em cimeiras glomeriformes com 3-4 flores; corola branca 1.D. radula

1. Lâmina foliar linear-lanceolada; nervuras secundárias inconspícuas; inflorescências bifloras; corola rosa 2.D. teres 
7.1. Diodella radula (Willd. \& Hoffmanns. ex Roem. \& Schult.) Delprete, Flora Ilustrada Catarinense Rubiáceas 1: 174. 2004 ESpermacoce radula Willd. \& Hoffmanns. ex Roem. \& Schult., Systema Vegetabilium 3: 531. 1818.

Figuras 41-43

Ervas perenes, eretas, ca. $40 \mathrm{~cm}$ alt. Ramos tetragonais, hirsutos. Folhas sésseis, lâmina lanceolada, verde escura, $2-5 \times 0,6-1 \mathrm{~cm}$, hirsuta, nervuras primária e secundárias proeminentes na superfície abaxial, 5-7 nervuras secundárias de cada lado, ápice agudo, base atenuada, margem inteira levemente revoluta; estípulas 5-6-fimbriadas. Inflorescência em cimeiras glomeriformes axilares, 3-4-floras; 2 brácteas foliáceas; flores sésseis; cálice 3-4 mm compr., sépalas ciliadas, 1-1,5 mm compr.; corola infundibuliforme, branca, 4-5 mm compr., glabra, lobos triangulares ciliados, 1-1,5 mm compr.; estames parcialmente exsertos, inseridos próximo à fauce da corola; filete semicilíndrico, 1-2 mm compr.; anteras elipsóides; ovário bilocular, um óvulo por lóculo; disco nectarífero bipartido; estilete cilíndrico, exserto, 3-6 mm compr.; estigma capitado. Fruto esquizocárpico, 2-5 × 2-3 mm, cálice persistente, semente plano convexa, castanho-escura, superfície dorsal lisa, superfície ventral com profundos sulcos.

Material examinado: BRASIL. Mato Grosso do Sul: Parque Estadual das Várzeas do Rio Ivinhema, 14-XI-2004, fl., Z.V. Pereira et al. 950 (DDMS); idem, 14-XI-2004, fl., Z.V. Pereira et al. 949 (DDMS); idem, 14-XI-2004, fl., Z.V. Pereira et al. 945 (DDMS); idem, 13-XI-2004, fl., Z.V. Pereira et al. 933 (DDMS); idem, 21-IV-2005, fl., Z.V. Pereira et al. 1203 (DDMS); idem, 11-VI-2004, fl., Z. V. Pereira et al. 638 (DDMS); idem, 15-VII-2003, fr., Z.V. Pereira et al. 746 (DDMS); idem, 12-V-2004, fl., fr., Z.V. Pereira et al. 659 (DDMS); idem, 24-XII-2003, fl., fr., Z.V. Pereira \& G. Lobcthenko 362 (DDMS).

Material adicional examinado: BRASIL. GoIÁs: Mossâmedes, 15-IV-1994, fl., J.A. Rizzo et al. 11270 (UFG). Mato Grosso do Sul: Amambaí, 20-III-2005, fl., fr., V.J. Pott et al. 7572 (UFG).

Diodella radula distribui-se pela América do Norte, América Central e América do Sul. No Brasil, ocorre nos Estados do Pará, Goiás, e Bahia até o Rio Grande do Sul (Andersson 1992, Delprete et al. 2004). No PEVRI, é amplamente distribuída, principalmente nos locais mais úmidos.

Essa espécie é de fácil reconhecimento no campo pelo porte herbáceo, folhas sésseis, lanceoladas, verde escuras mesmo quando secas, hirsutas, nervuras primárias e secundárias proeminentes na superfície abaxial, inflorescências com três ou quatro flores, corola branca, estames parcialmente exsertos, estilete exserto e estigma capitado. No PEVRI, floresce e frutifica de abril a dezembro.

7.2. Diodella teres (Walter) Small, Flora of Lancaster County: 271. $1913 \equiv$ Diodia teres Walter, Flora Caroliniana: 87. 1788.

Figuras 44-46

Ervas anuais, eretas, 10-40 cm alt. Ramos tetragonais, vilosos. Folhas sésseis, opostas; lâmina linear-lanceolada, verde amarelada, 1,5-4 × 0,5-1 cm, hirsuta, nervura primária proeminente na superfície abaxial e secundárias inconspícuas, ápice acuminado, base atenuada, margem inteira; estípulas 6-8-fimbriadas. Inflorescências bifloras, axilares; flores sésseis; cálice 1,5-3 mm compr., com 4 sépalas iguais, lobos triangulares, $1 \mathrm{~mm}$ compr., margem ciliada; corola tubulosa, rosa, 4-9 mm compr., externamente pouco pilosa e internamente com um anel de tricomas na porção inferior do tubo, lobos deltóides, $2 \mathrm{~mm}$ compr.; estames inseridos no tubo da corola, parcialmente inclusos; filete cilíndrico, 0,5 mm compr.; anteras oblongas; ovário bilocular, um óvulo por lóculo; disco nectarífero bipartido; estilete cilíndrico, exserto, 4-9 mm compr.; estigma capitado. Fruto esquizocárpico, obovado, 2-4,5 × 2-4 mm, cálice persistente, pericarpo resistente, castanho, cerdoso; sementes ovóides, plano-convexas, lisas, castanhas, levemente brilhantes, superfície dorsal lisa, superfície ventral com sulco longitudinal.

Material examinado: BRASIL. Mato Grosso Do Sul: Parque Estadual das Várzeas do Rio Ivinhema, 24-XII-2003, fl., fr., Z.V. Pereira \& G. Lobcthenko 346 (DDMS); idem, 13-XI-2004, fl., Z.V. Pereira et al. 904 (DDMS); idem, 5-II-2005, fl., fr., Z.V. Pereira et al. 998 (DDMS); idem, 5-II-2005, fl., Z.V. Pereira et al. 999 (DDMS); idem, 12-VI-2004, fl., fr., Z.V. Pereira et al. 659 (DDMS); idem, 9-II-2005, fl., Z.V. Pereira et al. 1010 (DDMS).

Material adicional examinado: BRASIL. BAHIA: Mucugê, 7-IX-1981, fl., A. Furlan et al. 1970 (UB); Barra da Estiva, 19-VII-1981, fl., fr., A.M. Giulietti et al. 1330 (UB); Espigão Mestre, 15-III-1972, fl., fr., W.R. Anderson et al. 37006 (UB). CEARÁ: Aimaba, 29-IV-1981, fl., fr., P. Martins s.n. (UB); Guaraciola do Norte, 8-IV-1982, fl., fr., P. Martins s.n. (UB). 
Diodella teres tem distribuição neotropical, ocorrendo no Sudeste dos Estados Unidos, América Central e América do Sul (Dwyer 1980, Kissmann \& Groth 2000). No Brasil, é encontrada por todo o território nacional (Andersson 1992). No PEVRI, distribui-se próximo à sede do Parque.

Essa espécie caracteriza-se por seu porte reduzido, folhas sésseis, linear-lanceoladas, verde amareladas, hirsutas, nervura primária proeminente e secundárias inconspícuas, inflorescências bifloras e flores róseas, axilares, sésseis. No PEVRI, floresce e frutifica o ano todo.

8. Emmeorhiza Pohl ex Endl., Genera Plantarum: 565. 1838.

Emmeorhiza é um gênero monoespecífico, exclusivamente sul-americano, encontra-se na ilha de Trinidad, Colômbia, Venezuela, Guianas, Peru, Bolívia, Brasil e Paraguai (Bacigalupo \& Cabral 2007). No Brasil, ocorre em quase todo o território nacional (Andersson \& Persson 1991, Bacigalupo \& Cabral 2007). No PEVRI, ocorre somente na borda da mata paludícola. Caracteriza-se pelo hábito escandente, flores disposta em cimeiras paniculiformes compostas de umbelas simples e pelas sementes falsamente aladas. Diferencia-se dos demais gêneros da Tribo Spermacoceae, sobretudo pela morfologia da inflorescência e deiscência do fruto.

8.1. Emmeorhiza umbellata (Spreng.) K. Schum., Flora Brasiliensis 6(6): 408. $1889 \equiv$ Borreria umbellata Spreng., Neve Entd. 2: 144. 1821. Figuras 47-50

Lianas. Ramos cilíndricos, passando a tetragonais no ápice, glabros. Folhas sésseis, lâmina lanceolada, 5,5-8 × 1,5-3 cm, glabra, nervuras primária e secundárias proeminentes na superfície abaxial, 4-5 nervuras secundárias de cada lado, ápice acuminado, base atenuada, margem inteira; estípulas persistentes, 4-8-fimbriadas. Inflorescência terminais e axilares, pedunculadas, pedúnculo $2-4 \mathrm{~cm}$, em cimeiras paniculiformes compostas de umbelas simples; brácteas e bractéolas foliáceas, elípticas a lanceoladas; flores pediceladas, pedicelos $3-5 \mathrm{~mm}$ compr.; cálice 2-2,5 mm compr., 4 sépalas iguais, lanceoladas, soldado somente na base; corola infundibuliforme, branca, 2-3 $\mathrm{mm}$ compr., glabra, lobos ovais lanceolados, 1-1,5 mm compr., levemente recurvada; estames inseridos na fauce da corola, exsertos; filete semicilíndrico, 1-1,5 mm compr., antera elíptica; ovário bilocular, um óvulo por lóculo; disco nectarífero inteiro; estilete cilíndrico 1-2 mm compr.; estigma bífido. Fruto cápsula septicida, obovóides, 3-4 × 1-1,5 mm, cálice persistente, papilosa; sementes elipsóides, pardo avermelhadas, aladas por uma membrana hialina.

Material examinado: BRASIL. Mato Grosso do Sul: Parque Estadual das Várzeas do Rio Ivinhema, 15-VIII-2003, fl., Z.V. Pereira et al. 751 (DDMS); idem, 22-IV-2005, fl., Z.V. Pereira et al. 1240 (DDMS); idem, 13-VII-2005, fl., Z.V. Pereira et al. 1346 (DDMS); idem, 13-VII-2005, fl., Z.V. Pereira et al. 1348 (DDMS).

Material adicional examinado: BRASIL. BAHIA: Jequié, 14-VII-1979, fl., fr., S.A. Mori \& R.M. King 12219 (UB); Santa Cruz de Cabrália, 6-VII-1979, fr., fl., S.A. Mori et al. 12142 (UB). Mato Grosso: Campo, 18-IX-1968, fl., fr., R.M. Harley \& R. Souza 10091 (UB). Mato Grosso do Sul: Três Lagoas, 20-IX-1964, fl., fr., J.C. Gomes Jr. 2194 (UB).

Espécie amplamente distribuída pela América do Sul, da Venezuela até o Brasil. No Brasil, ocorre nos Estados do Planalto Central Brasileiro, na região Nordeste e da faixa litorânea desde a Bahia até o Rio Grande do Sul (Andersson 1992). No PEVRI, encontra-se na margem da mata paludícola.

Emmeorhiza umbellata pode ser reconhecida no campo pelo hábito escandente e flores dispostas em inflorescência em cimeiras paniculiformes de umbelas. Steyermark (1974), baseado na dimensão das cápsulas, forma e tamanho das sépalas, propôs duas subespécies Emmeorhiza umbellata, subsp. umbellata e subsp. septentrionalis. Para cada subespécie, Steyermark (1974) também propôs duas variedades com base no indumento das folhas, ramos, pedicelo e cápsula. Os espécimes amostrados no PEVRI enquadram-se na subespécie umbellata var. umbellata por possuírem folhas e ramos glabros, cápsula papilosa e lobos do cálice lanceolados. Floresce e frutifica de abril a agosto.

9. Galianthe Griseb., Abhandlungen der Königlichen Gesellschaft der Wissenschaften zu Göttingen 24: 156. 1879.

Galianthe apresenta cerca de 50 espécies naturais de áreas tropicais da América Meridional, com centro de diversidade no sul do Brasil, Bolívia, Uruguai, Paraguai e norte da Argentina (Delprete et al. 2004). No Brasil, ocorrem cerca de 33 espécies distribuídas 
nos Estados da Bahia, Goiás, Mato Grosso do Sul, Minas Gerais, São Paulo, Paraná, Santa Catarina e Rio Grande do Sul (Cabral 1991). No PEVRI, ocorrem duas espécies distribuídas nas áreas mais úmidas do Parque.

As espécies deste gênero são frequentemente confundidas com as espécies de Borreria, contudo, segundo Cabral (1991), Galianthe pode ser diferenciado pelas flores distílicas, em tirsos laxos, sementes subcilíndricas com alas apicais, grãos de pólen esféricos, (6-)7(-8)-colporados, reticulados, com retículos diferenciados em supra-retículos e infra-retículos, oito cromossomos. Porém, nem todas as espécies apresentam inflorescência em tirsos como é o caso de G. brasiliensis. Este gênero foi criado por Grisebach (1879), com base na forma da inflorescência e abertura do fruto. Schumann (1891) tratou Galianthe como uma seção do gênero Borreria. Cabral \& Bacigalupo (1997) reabilitaram o gênero Galianthe, baseando-se na arquitetura da inflorescência, tipo de deiscência dos frutos, morfologia do pólen e número cromossômico (oito em Galianthe e 14 em Borreria). Terrell et al. (2002), baseados na morfologia da semente e os tipos de deiscência dos frutos, concluíram que Galianthe e Borreria não são suficientemente distintos. Dessein (2003), em estudo filogenético molecular, confirmou a categoria genérica de Galianthe.

Chave para identificação das espécies de Galianthe do PEVRI

1. Folhas elíptico-lanceoladas 3-6 mm compr.; estípulas 4-5-fimbriadas; inflorescências em fascículos paucifloros; pedúnculo $1 \mathrm{~cm}$ compr.; corola 1-3 mm compr. 1. G. brasiliensis

1. Folhas lanceoladas, $2-6,5 \mathrm{~cm}$ compr.; estípulas 8-9-fimbriadas; inflorescências em cimeiras corimbiformes; pedúnculo 10-13 cm compr., corola 4-5 mm compr. 2. G. centranthoides

9.1. Galianthe brasiliensis (Spreng.) E.L. Cabral \& Bacigalupo, Annals of the Missouri Botanical Garden 84(4): 861. 1997 D Diodia brasiliensis Spreng., Systema Vegetabilium, editio decima sexta 1: 406. 1825.

Figuras 51-53

Ervas, 0,5-1 m alt. Ramos tetragonais, glabros. Folhas sésseis; lâmina elíptico-lanceolada, 3-6 $\times 1-1,8 \mathrm{~mm}$, glabra, nervura primária proeminente na superfície abaxial, nervuras secundárias inconspícuas, ápice agudo, base aguda, margem inteira; estípulas 4-5-fimbriadas. Inflorescências em fascículos paucifloros, curto-pedunculadas, $1 \mathrm{~cm}$ compr., axilares e terminais, flores subsésseis; cálice 1-2 mm compr., com 4 sépalas iguais duas a duas; corola tubulosa, branca, 1-3 mm compr., externamente glabra, internamente com anel de tricomas na região basal do tubo, lobos triangulares, $0,3-0,5 \mathrm{~mm}$ compr.; estames inseridos na fauce da corola, exsertos; filete semicilíndricos 1-1,5 mm compr.; anteras oblongas; ovário bilocular, um óvulo por lóculo; disco nectarífero bipartido, 0,2 mm compr.; estilete cilíndrico, 1-2 mm compr., estigma bífido. Fruto esquizocárpico, separando-se a partir do ápice em dois mericarpo indeiscentes, marrom, 1,2-1,5 × 0,8-1,1 mm compr., cálice persistente; sementes oval-arredondadas, reticuladas, com o dorso convexo e o lado ventral com a parte superior dobrada para trás em ângulo aberto.

Material examinado: BRASIL. Mato Grosso DO Sul: Parque Estadual das Várzeas do Rio Ivinhema, 12-X-2006, fl., Z.V. Pereira et al. 1649 (DDMS); idem, 23-IV-2005, fl., Z.V. Pereira et al. 1275 (DDMS); idem, 6-IX-2005, fl., Z.V. Pereira et al. 275 (DDMS); idem, 6-IX-2003, fl., Z.V. Pereira et al. 298 (DDMS).

Material adicional examinado: BRASIL. BAHIA: Serra do Rio das Contas, 22-III-1977, fl., R.M. Harley s.n. (UB); Abaíra, 19-IV-1998, fl., L.P. Queiroz 5005 (UB); Piatã, 23-XII-1991, fl., R.M. Harley et al. s.n. (UB). Minas Gerais: Serra do Cabral, 8-III-1970, fl., H.S. Irwin s.n. (UB); Poutal, 23-IV-1958, fl., E.P. Heringer 6451 (UB).

Galianthe brasiliensis distribui-se do México até a Argentina (Andersson 1992, Burger \& Taylor 1993). No Brasil, distribui-se desde o Estado da Bahia até o Rio Grande do Sul (Andersson 1992). No PEVRI, foi encontrada na margem do rio Ivinhema. Esta espécie pode ser reconhecida pelas folhas reduzidas, estípulas 4-5-fimbriadas, inflorescências em fascículos paucifloros, curto-pedunculadas, flores brancas, 1-3 mm de comprimento. No PEVRI, floresce e frutifica de abril a dezembro.

9.2. Galianthe centranthoides (Cham. \& Schltdl.) E.L. Cabral, Boletín de la Sociedad Argentina de Botánica 27(3-4): 240. 1991 Borreria centranthoides Cham. \& Schltdl., Linnaea 3(4): 328. 1828.

Figuras 54-56

Erva perene, ereta, ca. $70 \mathrm{~cm}$ alt. Ramos tetragonais, glabros. Folhas sésseis, lâmina lanceolada, 


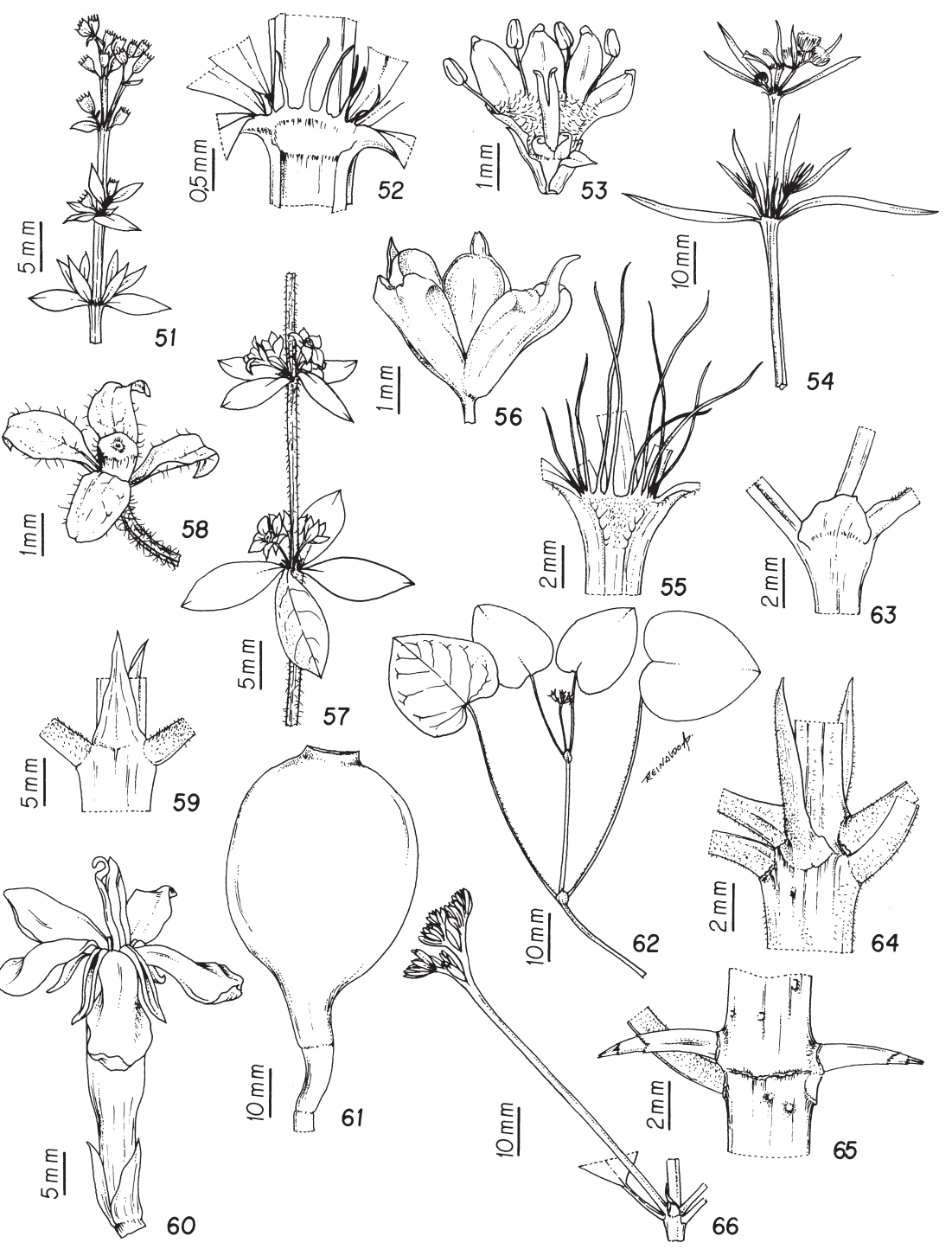

Figuras 51-66. Espécies de Rubiaceae do Parque Estadual das Várzeas do Rio Ivinhema, MS, Brasil. 51-53. Galianthe brasiliensis (Z.V. Pereira et al. 1649). 51. Ramos com inflorescência em fascículos paucifloros, axilares e terminais. 52. Estípulas fimbriadas. 53. Detalhe da flor aberta evidenciando os tricomas, anteras oblongas e estigma bífido. 54-56. Galianthe centranthoides (Z.V. Pereira \& G. Lobtchenko 1515). 54. Detalhe do ramo, folhas lanceoladas e inflorescência em cimeira corimbiforme. 55. Estípulas fimbriadas. 56. Fruto cápsula septicida abrindo do ápice até a metade. 57-58. Galium hypocarpium (Z.V. Pereira \& G. Lobtchenko 1519). 57. Detalhe do ramo e estípulas foliáceas. 58. Brácteas foliáceas involucrais. 59-61. Genipa americana (Z.V. Pereira et al. 229, Z.V. Pereira \& G. Lobtchenko 378). 59. Estípulas inteiras com ápice acuminado. 60. Detalhe da flor masculina, estilete exserto. 61. Fruto bacáceo subgloboso. 62-63. Geophila repens (Z.V. Pereira \& G. Lobtchenko 351). 62. Detalhe do ramo, folhas cordiformes. 63. Estípulas inteiras ovais. 64-66. Guettarda uruguensis (Z.V. Pereira \& G. Lobcthenko 437). 64. Detalhe das estípulas lanceoladas. 65. Detalhe dos espinhos. 66. Inflorescência em dicásio simples.

Figures 51-66. Rubiaceae species of the Parque Estadual das Várzeas do Rio Ivinhema, Mato Grosso do Sul State, Brazil. 51-53. Galianthe brasiliensis (Z.V. Pereira et al. 1649). 51. Branches with inflorescence in axillary and terminal, pauciflorous fascicles. 52 . Fimbriate stipules. 53. Detail of open flower showing trichomes, oblong anthers, and bifid stigma. 54-56. Galianthe centranthoides (Z.V. Pereira \& G. Lobtchenko 1515). 54. Detail of branch, with lanceolate leaves and cymose, corymbiform inflorescence. 55. Fimbriate stipules. 56. Septicidal capsule fruit, opening from the apex to midline. 57-58. Galium hypocarpium (Z.V. Pereira \& G. Lobtchenko 1519). 57. Details of the branch and foliaceous stipules. 58. Involucral, foliaceous bracts. 59-61. Genipa americana (Z.V. Pereira et al. 229, Z.V. Pereira \& G. Lobtchenko 378). 59. Entire stipules, acuminate apex. 60. Detail of male flower, with exserted stylus. 61. Subglobose, bacaceous fruit. 62-63. Geophila repens (Z.V. Pereira \& G. Lobtchenko 351). 62. Detail of branch, cordiform leaves. 63. Entire, oval stipules. 64-66. Guettarda uruguensis (Z.V. Pereira \& G. Lobcthenko 437). 64. Detail of lanceolate stipules. 65. Detail of thorns. 66. Inflorescence in simple dicasio. 
$2-6,5 \times 0,5-2 \mathrm{~cm}$, pubescente sobre as nervuras, nervuras primárias e secundárias proeminentes na superfície abaxial, 4-6 nervuras secundárias de cada lado, ápice acuminado, base atenuada, margem inteira, revoluta; estípulas 8-9-fimbriadas, pubescentes. Inflorescências em cimeiras corimbiformes, terminais, longo pedunculadas, $10-13 \mathrm{~cm}$ compr.; flores sésseis ou subsésseis, distílicas; cálice com quatro sépalas iguais, 3-5 mm compr., lobos triangulares, $1,5 \mathrm{~cm}$ compr.; corola infundibuliforme, branca, 4-5 mm compr., lobos triangulares, 2-3 mm compr., externamente pubescentes, internamente com anel de tricomas próximo a base do tubo; estames inseridos no tubo ou na fauce da corola, inclusos ou exsertos; filete semicilíndrico, 0,5-2 mm compr.; anteras subelipsóides; ovário bilocular, um óvulo por lóculo; disco nectarífero bipartido, 0,8-1 mm compr.; estilete cilíndrico, incluso ou exserto, 2-7 mm compr.; estigma bífido. Fruto cápsula septicida, separando-se apicalmente ou até a metade, cálice persistente; sementes elipsoides, plano-convexas, castanho-escuras, superfície ventral plana, superfície dorsal escrobiculada.

Material examinado: BRASIL. Mato Grosso do Sul: Parque Estadual das Várzeas do Rio Ivinhema, 15-XII-2005, fl., fr., Z.V. Pereira \& G. Lobtchenko 1515 (DDMS).

Material adicional examinado: BRASIL. SÃo PAULO: Itararé. 14-XI-1994, fl., V.C. Souza et al. 7270 (UEC).

Galianthe centranthoides distribui-se no Brasil, Paraguai, Uruguai e Argentina (Cabral \& Bacigalupo 1997). No Brasil, estende-se dos Estados de Goiás, Minas Gerais e São Paulo até o Rio Grande do Sul (Delprete et al. 2004). No PEVRI, ocorrem poucos indivíduos distribuídos próximo à mata paludícola.

Galianthe centranthoides diferencia-se de $G$. brasiliensis pelas folhas lanceoladas, com 2-6,5 × 0,5-2 cm, estípulas 8-9-fimbriadas, inflorescências em cimeiras multifloras, longos pedunculadas e flores maiores de $2 \mathrm{~mm}$ de comprimento. Vegetativamente é muito semelhante às espécies de Borreria, contudo, a morfologia da inflorescência e as flores distílicas, constituem caracteres diagnósticos importantes. No PEVRI, floresce e frutifica em dezembro.

10. Galium L., Species Plantarum 1: 105. 1753.

Galium possui cerca de 400 espécies, distribuídas pelas regiões temperadas do Hemisfério Norte e locais montanhosos dos Trópicos (Burger \& Taylor 1993). No Brasil, ocorrem cerca de 25 espécies (Dempster 1982, 1990, Jung-Mendaçolli 2003, 2007) distribuídas em quase todo o território nacional (Andersson 1992). No PEVRI, está representado por uma única espécie presente na margem direita do rio Ivinhema. Caracteriza-se por apresentar plantas com estípulas de dimensões e morfologia semelhantes às folhas, ausência de cálice, corola rotácea e dois estiletes livres ou concrescidos na base.

10.1. Galium hypocarpium (L.) Endl. ex Griseb., Flora of the British West Indian Islands 4:351.1861 $\equiv$ Valantia hypocarpia L., Syst. Nat., ed. 10: 1307. 1759.

Figuras 57 e 58

Ervas perenes, escandentes, ca. $30 \mathrm{~cm}$ alt. Ramos semitetragonais, hirsutos. Folhas sésseis, lâmina oblongo-lanceolada, $0,8-1,3 \times 0,3-0,7 \mathrm{~cm}$, hirsuta, nervura primária proeminente na superfície dorsal, nervuras secundárias inconspícuas, ápice agudo, base obtusa, margem inteira, parcialmente revoluta; estípulas foliáceas. Inflorescências axilares, 1-4-floro; 4 brácteas foliáceas, 2-3 mm compr., involucrais; flores pediceladas, pedicelos $0,2-1 \mathrm{~cm}$ compr.; cálice ausente; corola rotácea, branca, 2-3 mm compr., externamente pilosa, internamente glabra, lobos triangulares, $1,5 \mathrm{~mm}$ compr., ciliados; estames inseridos na fauce da corola, exsertos; filetes cilíndricos, 2-4 mm compr.; anteras oblongas; ovário bilocular, um óvulo por lóculo; disco nectarífero bipartido; dois estiletes cilíndricos, exsertos, 1-2 mm compr.; estigma 2, capitados. Fruto bacáceo, obovado, 2-3 $\times 3,3-3,6 \mathrm{~mm}$, alaranjado, pilosos; sementes plano-convexas, castanho-claras, superfície dorsal lisa, superfície ventral com sulco longitudinal.

Material examinado: BRASIL. Mato Grosso Do Sul: Parque Estadual das Várzeas do Rio Ivinhema, 15-XII-2005, fl., fr., Z.V. Pereira \& G. Lobtchenko 1519 (DDMS); idem, 23-XI-2003, fl., Z.V. Pereira et al. 341 (DDMS).

Material adicional examinado: BRASIL. GoIÁs: Chapada dos Veadeiros, 13-XI-1996, fr., fl., M.A. Silva \& A.J. Santos 3258 (UFG). Minas Gerais: Viçosa, estrada que dá acesso à trilha principal, 17-II-2002, fl., fr., Z.V. Pereira et al. 56 (VIC); Viçosa, 31-XII-1929, fl., Y. Mexia 4193 (VIC).

Esta espécie distribui-se no México, América Central, América do Sul e Antilhas (Dwyer 1980). 
No Brasil, ocorre em quase todo o território nacional (Andersson 1992). No PEVRI, foram encontrados poucos indivíduos distribuídos à margem direita do rio Ivinhema.

No PEVRI, G. hypocarpium pode ser reconhecida pelas estípulas foliáceas de dimensões e morfologia semelhantes a folhas, inflorescências axilares, 1-4-floras com quatro brácteas foliáceas, do mesmo tamanho da corola, cálice nulo e frutos alaranjados. Floresce e frutifica praticamente o ano todo.

11. Genipa L., Genera Plantarum ed. 5: 87. 1754.

Genipa apresenta cerca de sete espécies distribuídas pela Flórida, México, América Central e América do Sul (Dwyer 1980). No Brasil, ocorrem cerca de três espécies distribuídas por quase todo o território nacional (Andersson 1992). No PEVRI, ocorre somente uma espécie distribuída na mata ciliar do rio Ivinhema. Diferencia-se dos demais gêneros amostrados no PEVRI pelo porte arbóreo, estípulas inteiras, flores grandes, carnosas, amarelas no final da antese e prefloração contorcida. Além disso, a placentação parietal e muitas sementes dispostas horizontalmente constituem caracteres diagnósticos importantes.

\subsection{Genipa americana L., Systema Naturae, Editio Decima 2: 931. 1759.}

Figuras 59-61

Árvores, 5-7 m alt., dioica. Ramos cilíndricos, glabros. Folhas opostas congestas no ápice, pecioladas, pecíolo caniculado, 1-1,5 cm compr., pubescente; lâmina oblanceolada, $22-25 \times 8,5-12 \mathrm{~cm}$, pubescente, nervuras primária e secundárias proeminentes na superfície abaxial, 9-15 nervuras secundárias de cada lado, ápice obtuso, base atenuada, margem inteira; estípulas triangulares, ápice acuminado. Inflorescências em cimeiras 1-2-floro, terminais ou axilares; brácteas lanceoladas; flores curto-pediceladas, pentâmeras; cálice campanulado, 1-4 cm compr.; corola hipocrateriforme, brancas 5-6 cm compr., externamente pubescente, internamente com anel de tricomas próximo a base, lobos ovais, 1,5-2,5 cm compr.; estames inseridos na fauce da corola, exsertos; anteras sésseis, ápice apiculado, oblongas; ovário bilocular, muitos óvulos por lóculos; disco nectarífero inteiro; estilete cilíndrico, exserto, 2,5-3 cm compr.; estigma bífido. Frutos bacáceo, subgloboso, marrom-acinzentados, 6-10 × 4-8 cm, cálice persistente; sementes arredondadas, achatadas.

Material examinado: BRASIL. Mato Grosso Do Sul: Parque Estadual das Várzeas do Rio Ivinhema,
27-XII-2003, fr., Z.V. Pereira \& G. Lobtchenko 378 (DDMS); idem, 6-IX-2003, fl., Z.V. Pereira et al. 229 (DDMS); idem, 28-III-2004, fr., Z.V. Pereira et al. 525 (DDMS).

Material adicional examinado: BRASIL. GoIÁs: Alto Paraíso, 14-VI-1994, fr., J.A. Ratter et al. 7338 (UB). Espírito SAnto: Linhares, 17-X-1883, fr., O. Guimarães et al. s.n. (CGMS). Mato Grosso: Base-Campo, 21-VI-1968, fr., J.A. Ratter et al. s.n. (UB); Jataí, 26-VI-1966, fr., D.R. Hunt 6184 (UB).

Genipa americana distribui-se pela Flórida, México, América Central e América do Sul (Dwyer 1980). No Brasil, ocorre em quase todo o território nacional, tanto em estado natural como cultivada. No PEVRI, foram amostrados poucos indivíduos distribuídos nas margens do rio Ivinhema. Essa espécie é de fácil reconhecimento pelo porte arbóreo, folhas opostas congestas no ápice do ramo, escuras quando secas, inflorescências 1-2-floras, flores grandes, amareladas no final da antese e frutos grandes marrom-acinzentados. Floresce de outubro a dezembro e frutifica de janeiro a março.

12. Geophila D. Don, Prodromus Florae Nepalensis: 136. 1825.

Geophila apresenta cerca de 20 espécies distribuídas pela América Tropical, África e Ásia (Burger \& Taylor 1993). No Brasil ocorrem cerca de seis espécies distribuídas por quase todo o território nacional (Andersson 1992). No PEVRI, ocorre somente uma espécie distribuída pelo interior da mata ciliar do rio Ivinhema e nas áreas de transição entre a Floresta Estacional Semidecidual e o Cerrado.

As espécies desse gênero podem ser reconhecidas por serem ervas reptantes, com estípulas frequentemente inteiras, folhas longo-pecioladas, lâmina foliar cordada, flores em inflorescências pedunculadas e frutos drupáceos, carnosos, contendo duas sementes. Segundo Burger \& Taylor (1993), as espécies desse gênero são frequentemente confundidas com espécies de Coccocypselum contudo, este gênero apresenta frutos azuis com muitas sementes, enquanto Geophila apresenta frutos alaranjados ou vermelhos e somente duas sementes.

12.1. Geophila repens (L.) I.M. Johnst., Sargentia 8: 281. $1949 \equiv$ Rondeletia repens L., Systema Naturae, Editio Decima 2: 928. 1759.

Figuras 62, 63

Ervas perenes, reptantes. Ramos cilíndricos, glabros, entrenós 3-7 cm compr.. Folhas pecioladas, 
pecíolo semicilíndrico, 3-7 cm compr., pubescentes; lâmina oval a cordiforme, 2,5-3 ×3-3,5 cm, pubescente na superfície abaxial, nervuras primária e secundárias proeminentes na superfície abaxial, 4-5 nervuras secundárias de cada lado, ápice obtuso, base cordada, margem inteira; estípulas inteiras, persistentes ovais. Inflorescências pedunculadas, pedúnculo 0,5-3 cm compr., cimeiras fasciculadas 2-4-floras, terminais; brácteas lineares, pubescentes; flores pediceladas, pedicelo 1-3 mm compr., pentâmeras; cálice com sépalas lanceoladas, superfície abaxial com glândulas na porção basal, 2-3 mm compr.; corola infundibuliforme, branca, carnosa, 7-10 mm compr., glabras, lobos ovados, 3-5 mm compr.; estames inseridos no terço superior do tubo, inclusos; filete semicilíndrico, 1-2 mm compr.; anteras elipsoides; ovário bilocular, um óvulo por lóculo; disco nectarífero inteiro, 0,5-0,7 mm compr.; estilete cilíndrico exserto, 6-9 mm compr.; estigma bífido. Fruto drupáceo, elipsóide, vermelho, $8 \times 6 \mathrm{~mm}$, cálice persistente; sementes plano-convexas, superfície ventral plana e lisa.

Material examinado: BRASIL. MAto Grosso DO Sul: Parque Estadual das Várzeas do Rio Ivinhema, 26-XII-2003, fl., fr., Z.V. Pereira \& G. Lobtchenko 351 (DDMS); idem, 27-III-2004, fl., Z.V. Pereira et al. 458 (DDMS); idem, 5-II-2005, fr., Z.V. Pereira et al. 986 (DDMS).

Material adicional examinado: BRASIL. BAHIA: Ibicaraí, 17-III-1979, fr., S.A. Mori et al. s.n. (UB); Lineus, 27-VII-1978, fl., fr., G. Lisboa 2 (UB); Barra do Choça, 15-III-1979, fl., S.A. Mori et al. s.n. (UB). Mato Grosso do Sul: Bodoquena, 23-V-2002, fl., fr., U.M. Resende et al. 922 (CGMS); Corumbá, 4-VII-1998, fl., fr., G.A. Damasteno Jr. et al. 5319 (UB).

Geophila repens distribui-se pelo México, América Central, Antilhas, América do Sul, África, Filipinas e Oeste do Pacífico (Steyermark 1974, Verdcourt 1976, Burger \& Taylor 1993). No Brasil, ocorre por quase todo o território nacional (Andersson 1992). No PEVRI, foi encontrada na mata ciliar do rio Ivinhema e nas áreas de transição entre a Floresta Estacional Semidecidual e o Cerrado.

Essa espécie é de fácil reconhecimento no campo, pelo hábito reptante, entrenós longos, folhas longo-pecioladas, cordiformes, estípulas ovais, inflorescência pedunculada, em cimeiras fasciculadas e frutos drupáceos vermelhos com duas sementes.
Alguns autores como Verdcourt (1976) e Burger \& Taylor (1993), referem à presença de tricomas na superfície adaxial da corola, contudo, nos espécimes analisados, a corola é totalmente glabra corroborando o que foi afirmado por Dillenburg \& Porto (1985) para o Estado do Rio Grande do Sul e Jung-Mendaçolli (2007) para São Paulo. No PEVRI, floresce de outubro a março, e frutifica de dezembro a abril.

\section{Guettarda L., Species Plantarum 2: 991. 1753.}

Guettarda apresenta cerca de 139 espécies distribuídas pela América Tropical, sendo que somente duas ocorrem na Oceania e na região do Oceano Índico (Steyermark 1974). No Brasil, ocorrem 21 espécies distribuídas em todo o território nacional (Andersson 1992, Barbosa 2007). No PEVRI, ocorrem duas espécies distribuídas nos fragmentos de transição entre o Cerrado e a Floresta Estacional Semidecidual. As espécies desse gênero podem ser reconhecidas pelas estípulas inteiras, inflorescências pedunculadas, em cimeiras dicotômicas dispostas unilateralmente, flores hermafroditas ou unissexuais, ovário 2-9-locular e estigma capitado ou ligeiramente bilobado.

Chave para identificação das espécies de Guettarda do PEVRI

1. Ramos com dois espinhos por nó; corola 1-1,5 cm compr., internamente glabra; ovário com dois a quatro lóculos; fruto elipsóide 1. G. uruguensis

1. Ramos inermes; corola 2,5-3,5 cm comp., indumento em ambas as superfícies; ovário trilocular; frutos globosos .... 2. G. viburnoides

13.1. Guettarda uruguensis Cham. \& Schltdl., Linnaea 4: 183. 1829.

Figuras 64-66

Arvoreta, ca. 2,5 m alt. Ramos cilíndricos, pubescentes, lenticelados, dois espinhos por nó. Folhas pecioladas, pecíolo semicilíndrico, 1-1,5 cm compr.; lâmina elíptica, 5-9 × 2,5-4 cm, velutina, nervuras primária e secundárias proeminentes na superfície abaxial, 7-9 nervuras secundárias de cada lado, ápice acuminado, base obtusa, margem inteira; estípulas inteiras, caducas, lanceoladas, ápice acuminado. Inflorescências pedunculadas, pedúnculo 4-8,5 cm compr., dicásios simples; brácteas ausentes, bractéolas lanceoladas; flores sésseis, dispostas unilateralmente; cálice duas sépalas, 4-6 mm compr., pilosos, lobos triangulares, 
1-1,5 mm compr.; corola hipocrateriforme, branca, 1-1,5 cm compr., externamente velutina, internamente glabra, 4-6-lobada, lobos lanceolados, 3-4 mm compr.; estames inseridos no terço superior do tubo, inclusos, subsésseis; anteras lanceoladas; ovário variando de dois a quatro lóculos no mesmo indivíduo, um óvulo por lóculo; disco nectarífero inteiro, tomentoso; estilete cilíndrico, exserto, 1-1,5 cm compr., estigma capitado. Fruto drupáceo, elipsóide, 1,5-2,5 × 1-2 cm, cálice persistente, velutino; sementes cilíndricas.

Material examinado: BRASIL. Mato Grosso do Sul: Parque Estadual das Várzeas do Rio Ivinhema, 13-III-2004, fl., Z.V. Pereira \& G. Lobcthenko 437 (DDMS); idem, 10-VI-2004, fr., Z.V. Pereira et al. 591 (DDMS).

Material adicional examinado: BRASIL. GoIÁs: Luziânia, 26-II-1975, fr., E.P. Heringer 14430 (UB); Goiânia, 5-XI-1968, fr., J.A. Rizzo et al. 2717 (UB); Goiânia, 4-XI-1968, fl., J.A. Rizzo et al. 2634 (UB); Goiânia, 1-I-1969, fl., J.A. Rizzo et al. 3299 (UB). Mato Grosso: Chapada dos Guimarães, 8-IX-2000, fr., L.A. Neto \& M. Aragona 1273 (UB).

Guettarda uruguensis distribui-se pela Bolívia, Brasil, Argentina e Uruguai (Delprete et al. 2005). No Brasil, ocorre dos Estados da Bahia e Minas Gerais até o Rio Grande do Sul. No PEVRI, foi amostrado um único indivíduo encontrado próximo à mata paludícola.

Essa espécie é vegetativamente muito semelhante às espécies de Chomelia. Contudo, é possível diferenciá-la pelas inflorescências pedunculadas em dicásios, flores sésseis dispostas unilateralmente, cálice com duas sépalas muito reduzidas, corola com quatro a seis pétalas, ovário variando de dois a quatro lóculos no mesmo indivíduo e estigma capitado. No PEVRI, floresce de outubro a março e frutifica de dezembro a julho.

\subsection{Guettarda viburnoides Cham. \& Schltdl.,}

Linnaea 4: 182. 1829.

Figuras 67,68

Árvore, ca. $5 \mathrm{~m}$ alt. Ramos cilíndricos, glabros, inermes. Folhas pecioladas, pecíolo semicilíndrico, 2-2,5 cm compr.; lâmina elíptica, 7-12 $\times 5-7 \mathrm{~cm}$, velutina na superfície abaxial, nervuras primária e secundárias proeminentes na superfície abaxial, nervuras secundárias 8-10 de cada lado, ápice agudo, base obtusa, margem inteira; estípulas inteiras, caducas, triangulares, ápice acuminado.
Inflorescências em cimeiras pedunculadas, pedúnculo 3-7 cm compr., axilares; brácteas ausentes, bractéolas lanceoladas; flores sésseis, dispostas unilateralmente; cálice com duas sépalas, 4-7 mm compr., pilosos, lobos curto triangulares, $0,5-0,8 \mathrm{~mm}$ compr.; corola hipocrateriforme, branca, 2,5-3,5 cm compr., externa e internamente velutina, cinco lobos lanceolados, 6-10 mm compr.; estames inseridos no terço superior da corola, inclusos; filete semicilíndrico, $2 \mathrm{~mm}$ compr.; anteras, lanceoladas; ovário trilocular, um óvulo por lóculo; disco nectarífero inteiro, velutino; estilete cilíndrico, velutino, exserto, 2-3 cm compr., estigma capitado. Fruto drupáceo, globoso, 2-2,5 × 1,5-2,5 cm, cálice persistente; sementes cilíndricas.

Material examinado: BRASIL. Mato Grosso do Sul: Parque Estadual das Várzeas do Rio Ivinhema, 16-II-2004, fr., Z.V. Pereira et al. 424 (DDMS); idem, 12-III-2005, fr., Z.V. Pereira et al. 1114 (DDMS).

Material adicional examinado: BRASIL. BAHIA: Serra da Água de Rega, 27-II-1971, fr., H.S. Irwin et al. s.n. (UB). Mato Grosso do Sul: Aquidauana, 14-X-1990, fl., U.M. Resende 222 (CGMS); Bonito, 16-XII-2000, fl., fr., P.V. Gonçalves et al. 2045 (CGMS).

Guettarda viburnoides distribui-se pelo Brasil, Paraguai e Argentina (Andersson 1992). No Brasil, ocorre em quase todo o território nacional exceto nos Estados de Roraima e Amazonas (Andersson 1992). No PEVRI, foi amostrado um único indivíduo no fragmento de transição, na saída do Parque. Diferencia-se de G. uruguensis pelos ramos inermes, corola com 2,5-3,5 cm de comprimento, indumento presente em ambas as faces, ovário trilocular e frutos globosos. No PEVRI, floresce de setembro a novembro e frutifica de dezembro a março.

14. Manettia Mutis ex L., Mantissa Plantarum 2: 553, 558. 1771.

Manettia é um gênero com aproximadamente 120 espécies naturais da América Central e Meridional (Delprete et al. 2005). No Brasil, ocorrem cerca de 30 espécies distribuídas por todo o território brasileiro (Andersson 1992, Macias 1998). No PEVRI, ocorre uma única espécie distribuída na área de pastagem.

As espécies desse gênero podem ser reconhecidas pelo hábito herbáceo ou trepador, flores geralmente vistosas, muitos óvulos por lóculo, fruto cápsula septicida, oblonga, ovóide ou arredondada e sementes aladas. No PEVRI, diferencia-se dos demais gêneros pelo hábito trepador associado a flores vistosas. 


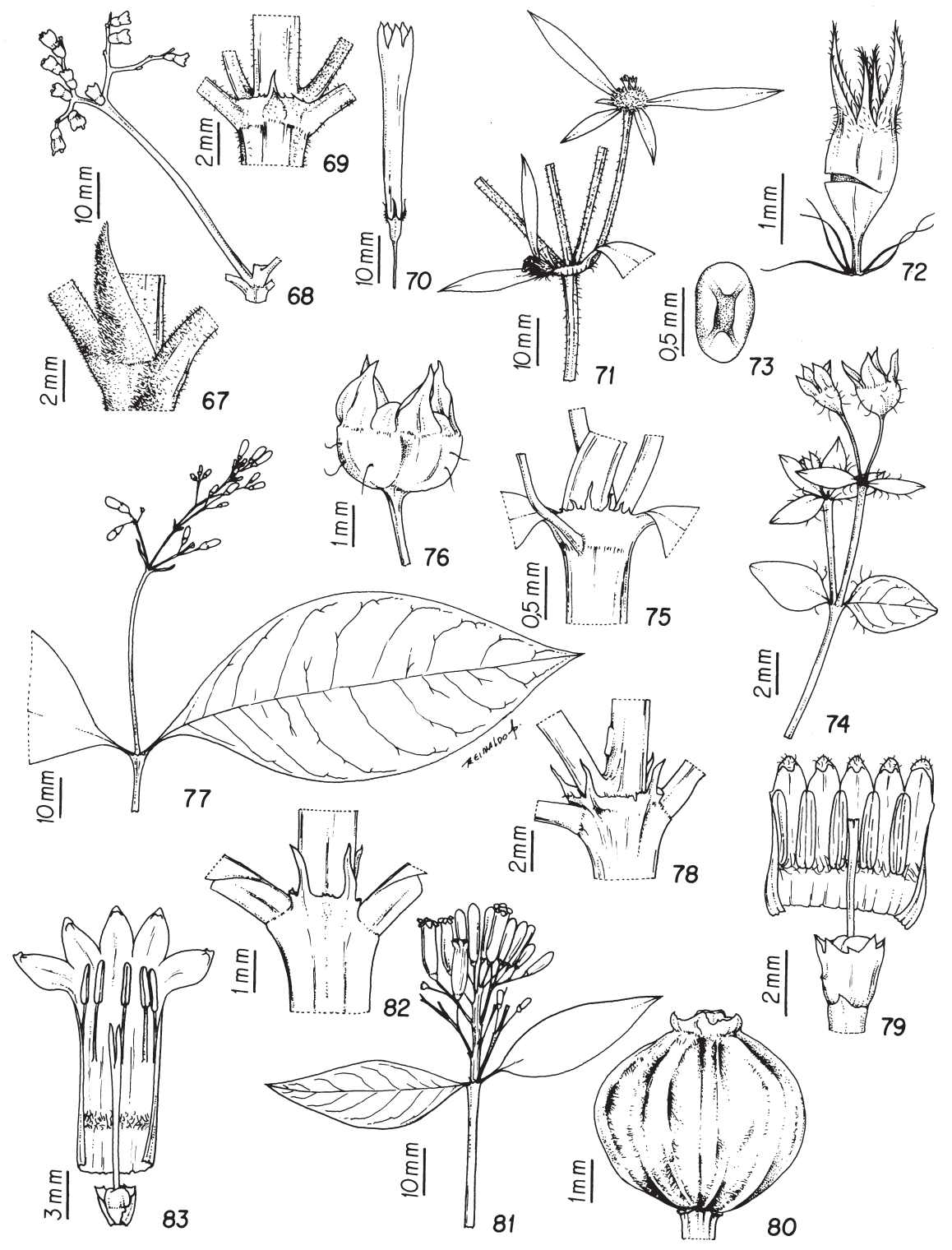

Figuras 67-83. Espécies de Rubiaceae do Parque Estadual das Várzeas do Rio Ivinhema, MS, Brasil. 67-68. Guettarda viburnoides (Z.V. Pereira et al. 424). 67. Estípulas inteiras com ápice acuminado. 68. Detalhe da inflorescência. 69-70. Manettia cordifolia (Z.V. Pereira et al. 1394). 69. Estípulas inteiras com ápices curto-acuminados. 70. Detalhe da flor pedicelada, tetrâmera. 71-73. Mitracarpus villosus (Z.V. Pereira et al. 362). 71. Detalhe do ramo, inflorescência glomeriforme com quatro brácteas foliáceas. 72 . Fruto com deiscência circuncisa; 73. Semente com a superfície ventral com depressão em forma de "X". 74-76. Oldenlandia salzmannii (Z.V. Pereira et al.1669). 74. Detalhe do ramo com folhas oval-lanceoladas e margem ciliada. 75. Estípulas fimbriadas. 76. Fruto cápsula loculicida, cálice persistente. 77-80. Palicourea croceoides (Z.V. Pereira et al. 226, 983). 77. Inflorescência paniculiforme. 78. Estípulas bipartidas com ápice acuminado. 79. Detalhe da flor dissecada. 80. Fruto drupáceo globoso. 81-83. Palicourea fastigiata (Z.V. Pereira et al. 235). 81. Inflorescência corimbiforme. 82. Estípulas bipartidas lanceoladas. 83. Detalhe da flor dissecada.

Figures 67-83. Rubiaceae species of the Parque Estadual das Várzeas do Rio Ivinhema, Mato Grosso do Sul State, Brazil. 67-68. Guettarda viburnoides (Z.V. Pereira et al. 424). 67. Entire stipules, acuminate apex. 68. Detail of inflorescence. 69-70. Manettia cordifolia (Z.V. Pereira et al. 1394). 69. Entire stipules, with short-acuminate apex. 70. Detail of pedicellate, tetramerous flower. 71-73. Mitracarpus villosus (Z.V. Pereira et al. 362). 71. Detail of branch, glomerulate inflorescence with four foliaceous bracts. 72. Fruit with circumferential dehiscence. 73. Seed with the ventral surface with an "X"-shaped depression. 74-76. Oldenlandia salzmannii (Z.V. Pereira et al.1669). 74. Detail of branch with oval-lanceolate leaves and ciliate margins. 75. Fimbriate stipules. 76. Loculicidal capsule fruit, calyx persistent. 77-80. Palicourea croceoides (Z.V. Pereira et al. 226, 983). 77. Paniculate inflorescence. 78. Bipartite stipules with acuminate apex. 79. Detail of dissected flower. 80. Globose, drupaceous fruit. 81-83. Palicourea fastigiata (Z.V. Pereira et al. 235). 81. Corymbiform inflorescence; 82. Lanceolate, bipartite stipules; 83. Detail of dissected flower. 
14.1. Manettia cordifolia Mart., Denkschriften der Königlichen Akademie der Wissenschaften zu Muenchen 9: 95, t. 7. 1824.

Figuras 69, 70

Trepadeiras. Ramos cilíndricos, pubescentes. Folhas curto-pecioladas, pecíolo semicilíndricos, 0,5-1 cm compr., velutino; lâmina oval, $1-2,5 \times 0,5-1,3 \mathrm{~cm}$, velutina, nervuras primárias e secundárias proeminentes na superfície abaxial, 3-4 nervuras secundárias de cada lado, ápice acuminado, base obtusa, margem inteira; estípulas persistentes, inteiras, triangulares, curto acuminada. Inflorescências unifloras, em cimeiras axilares; brácteas foliáceas, lanceoladas, velutina; flores pediceladas, pedicelo 1,5-6 cm compr., tetrâmeras; cálice $0,6-1 \mathrm{~cm}$ compr., lobos triangulares a subulados, 2-5 mm compr.; corola tubulosa-claviforme, vermelha, $2-5 \mathrm{~cm}$ compr., externamente glabras, internamente com anel de tricomas na porção basal, lobos triangulares, reflexo na flor em antese, 0,6-1 cm compr.; estames inseridos na fauce da corola, parcialmente exsertos; filetes semicilíndricos, 3-4 mm compr.; anteras elipsoides; ovário bilocular, muitos óvulos por lóculo; disco nectarífero bipartido, $1 \mathrm{~mm}$ compr.; estilete cilíndrico, exserto, 2-5 cm compr.; estigma bífido. Fruto cápsula septicida, oblonga, 1-2 $\times 0,5-1 \mathrm{~cm}$, cálice persistente; sementes castanho-escuras, aladas, oblongas.

Material examinado: BRASIL. Mato Grosso do Sul: Parque Estadual das Várzeas do Rio Ivinhema, 13-VII-2005, fl., fr., Z.V. Pereira et al. 1394 (DDMS).

Material adicional examinado: BRASIL. BAHIA: Morro do Chapéu, 17-V-1978, fl., J.S. Silva 540 (UFG); Campo Formoso, 5-IX-1981, fl., fr, R.P. Orlandi 518 (UFG); Jacobina, 25-VII-1980, fl., R.P. Orlandi 253 (UFG); Morro do Chapéu, 2-V-1980, fl., R.M. Harley s.n. (UFG); Morro do Chapéu, 26-VII-1980, fl., H.P. Bautista 369 (UFG).

Manettia cordifolia apresenta ampla distribuição, ocorrendo desde o Peru até o Paraguai (Macias 1998, Delprete et al. 2005). No Brasil, distribui-se por quase todos os Estados (Andersson 1992, Delprete et al. 2005). No PEVRI, foi registrado somente um indivíduo na região norte do Parque, área que ainda sofre grande pressão antrópica. Essa espécie é de fácil reconhecimento, pois é a única que apresenta hábito trepador associado a flores vistosas, vermelhas e fruto do tipo cápsula septicida. Floresce e frutifica durante o ano todo.
15. Mitracarpus Zucc. ex Schult. \& Schult. f., Mant. 3: 210, 399. 1827.

Mitracarpus é constituído por cerca de 40 espécies com distribuição no México, América Central, América do Sul, Antilhas e África (Dwyer 1980). No Brasil, está representado por 16 espécies distribuídas em quase todo o território nacional (Pereira 1954, Dimitri 1959, Porto et al. 1977, Andersson 1992). No PEVRI, está representado por uma única espécie amplamente distribuída no Parque. Mitracarpus apresenta afinidade morfológica com Borreria, contudo a deiscência do fruto e a morfologia da semente constituem características essenciais para a separação dos gêneros.

15.1. Mitracarpus villosus (Sw.) DC., Prodomus Systematis Naturalis Regni Vegetabilis 4: 572.1830 $\equiv$ Spermacoce villosa Sw., Nova Genera et Species Plantarum seu Prodromus: 29. 1788.

Figuras 71-73

Ervas anuais, eretas, ca. $50 \mathrm{~cm}$ alt. Ramos tetragonais pilosos. Folhas subsésseis, verde amareladas; lâmina lanceolada, 2-6 × 1-2 cm, hirsuta, nervuras primária e secundárias proeminentes na superfície abaxial, impressa na superfície adaxial, 3-4 nervuras secundárias de cada lado, ápice agudo, base atenuada, margem inteira; estípulas persistentes 7-9-cerdosas. Inflorescências em cimeiras glomeriformes, terminais ou axilares, multifloras; 4 brácteas foliáceas lanceoladas; flores sésseis; cálice com 4 sépalas iguais duas a duas; corola tubulosa, branca, 3-4 mm compr., externamente pilosa no terço superior, internamente com anel de tricomas próximo a base, lobos triangulares, 0,6-0,8 $\mathrm{mm}$ compr.; estames inseridos na fauce da corola, exsertos; filete semicilíndrico, 0,5-0,7 mm compr.; anteras elipsoides; ovário bilocular, um óvulo por lóculo; disco nectarífero inteiro; estilete cilíndrico, exserto, 2-3 mm compr.; estigma bífido. Fruto cápsula circuncisa, pilosa no terço superior, subglobosa, 1-3,5 × 1-2 mm, cálice persistente; sementes subelipsóides, castanhas, superfície dorsal reticulada, superfície ventral plana com depressão em forma de "x".

Material examinado: BRASIL. Mato Grosso do SuL: Parque Estadual das Várzeas do Rio Ivinhema, 6-IX-2003, fl., Z.V. Pereira et al. 284 (DDMS); idem, 26-XII-2003, fl., fr., Z.V. Pereira et al. 362 (DDMS); idem, 13-XI-2004, fl., Z.V. Pereira et al. 930 (DDMS); idem, 13-VII-2005, fl., Z.V. Pereira et al. 1346 (DDMS); idem, 13-III-2005, fl., Z.V. Pereira et al. 1135 (DDMS). 
Material adicional examinado: BRASIL. São PAULO: Campinas, Faz. Santa Genebra, 9-IV-1985, fl., A. Klein s.n. (UEC); Campinas, 19-II-1979, fl., fr., M. Polo s.n. (UEC). Minas Gerais: Brumadinho, Retiro das Pedras, 10-V-1994, fl., J. Semir \& J.R. Stehmann s.n. (UEC).

Mitracarpus villosus é amplamente distribuída, ocorrendo por toda a América Tropical, África e Índia (Burger \& Taylor 1993, Delprete et al. 2005). No Brasil, ocorre em todo o território nacional (Andersson 1992). No PEVRI, distribui-se por toda a sua extensão, principalmente nas áreas mais alteradas.

Vegetativamente essa espécie é muito semelhante às espécies de Borreria, porém, no PEVRI, é possível seu reconhecimento pela folhas verde-amareladas, estípulas cerdosas, deiscência circuncisa do fruto e semente com depressão em forma de "x" na superfície ventral. Segundo Souza (1997), essa espécie é frequentemente confundida com M. hirtus, contudo, $M$. villosus apresenta semente não sulcada na superfície dorsal, enquanto que em $M$. hirtus as sementes apresentam uma depressão cruciforme na superfície dorsal. No PEVRI, floresce e frutifica o ano todo.

16. Oldenlandia L., Species Plantarum 1: 119. 1753.

Oldenlandia apresenta cerca de 100 espécies distribuídas pelas regiões tropicais e temperadas da América, África, Ásia e ilhas do Pacífico (Burger \& Taylor 1993, Delprete et al. 2005, Jung-Mendaçolli 2007). No Brasil, ocorrem cerca de sete espécies distribuídas por quase todos os Estados (Andersson 1992). No PEVRI, foi amostrada uma única espécie nas várzeas, próxima à trilha de acesso ao Parque. As espécies desse gênero podem ser reconhecidas pelo hábito herbáceo, estípulas inteiras ou fimbriadas, flores pediceladas, frequentemente tetrâmeras, fruto cápsula loculicida e sementes arredondadas.

16.1. Oldenlandia salzmannii (DC.) Benth. \& Hook. f. exA.B. Jacks., Index Kewensis 2: 58. $1873 \equiv$ Anotis salzmannii DC., Prodromus (A.P. De Candolle) 4: 433. 1830.

Figuras 74-76

Ervas anuais, 10-20 cm alt., prostradas. Ramos semicilíndricos ou tetragonais, glabros ou pubescentes. Folhas curto-pecioladas, pecíolos semicilíndricos, $1 \mathrm{~mm}$ compr., glabros; lâmina oval-lanceolada, 2-10 × 2-6 mm, nervura primária proeminente na superfície abaxial, nervuras secundárias inconspícuas, glabras, ápice agudo, base obtusa, margem inteira ciliada; estípulas 5-7-fimbriadas curtas. Inflorescências terminais ou axilares 1-3-floras; flores distílicas, pediceladas, pedicelo 2-10 mm compr.; cálice com 4 sépalas, 1-2 mm compr., lobos triangulares, glabros ou pubescentes; corola infundibuliforme, púrpura, 2-5 mm compr., externamente glabra, internamente pubescente próximo a base, lobos triangulareslanceolados, 1-2 mm compr.; estames inseridos na fauce ou no tubo da corola, inclusos ou exsertos, filete semicilíndricos, 0,5-1,5 mm compr., anteras lanceoladas; ovário bilocular, um óvulo por lóculo; disco nectarífero inteiro, 0,2 $\mathrm{mm}$ compr., estilete cilíndrico, incluso ou exserto, 1,5-5 mm compr.; estigma bífido. Fruto cápsula loculicida, subglobosa, papirácea, 1-1,5 × 2-3 mm, cálice persistente; sementes trígonas, superfície reticulada.

Material examinado: BRASIL. Mato Grosso do Sul: Parque Estadual das Várzeas do Rio Ivinhema, 12-X-2006, fl., fr., Z.V. Pereira et al.1669 (DDMS).

Material adicional examinado: BRASIL. MINAS GeraIs: Diamantina, Jaboticabas, 31-X-1973, fl., I. Sazima s.n. (UEC); Santana do Riacho, Lapinha, Serra do Sipó, 23-XI-2000, fl., A.M.G.A. Tozzi \& L.S. Kinoshita s.n. (UEC). BAHIA: Jacobina, Lagoa Antônio Sobrinho, 25-VI-1999, fl., F. Franco et al. 3117 (UEC). PARANÁ: União da Vitória, 16-X-1966, fl., G. Hastschbach 14881 (UEC).

Oldenlandia salzmannii distribui-se pelo Brasil, Paraguai, Argentina e Uruguai (Andersson 1992, Delprete et al. 2005). No Brasil, ocorre no Nordeste e nos Estados de Mato Grosso do Sul, Paraná, São Paulo e Santa Catarina (Andersson 1992, Delprete et al. 2005). No PEVRI, foi amostrado um único indivíduo crescendo nas várzeas, próximas à trilha de acesso ao Parque.

Essa espécie pode ser reconhecida no campo pelo porte, muito pequeno, folhas reduzidas, nervuras secundárias inconspícuas, inflorescência com 1-3 flores, flores distílicas, púrpuras e pequenas e fruto cápsula loculicida. Floresce de setembro a janeiro e frutifica de novembro a fevereiro.

17. Palicourea Aubl., Hist. Pl. Guiane Française 1: 172. 1775.

Palicourea compreende cerca de 200 espécies, distribuídas na América Central, América do Sul e Antilhas (Dwyer 1980, Taylor 1997). Taylor (1997) comentou que, na América do Sul, esse gênero é encontrado em pequenas elevações e em florestas tropicais úmidas fazendo parte do estrato arbustivo. No 
Brasil, distribui-se em quase todo o território nacional (Pereira 1954, Smith \& Downs 1956, Andersson 1992, Delprete et al. 2005). Segundo Taylor (1989), o Brasil, especialmente a bacia amazônica e o planalto central, representam um dos seus centros de dispersão. No PEVRI, está representado por quatro espécies amplamente distribuídas no Parque.

Vegetativamente, os gêneros Palicourea e Psychotria são muito semelhantes, inviabilizando uma distinção segura entre eles. Muller $(1881,1888)$ considerou o gênero Palicourea como uma seção de Psychotria. Segundo Steyermark (1972, 1974), Taylor (1989) e Burger \& Taylor (1993), os caracteres utilizados para o reconhecimento de Palicourea são: pedúnculos das inflorescências coloridos, da mesma cor das corolas, frequentemente, azuis, púrpuras, amarelas, laranjas, vermelhas ou a combinação destas cores; flores pediceladas com linha de articulação entre pedicelo e o receptáculo, e tubo da corola curvado ou giboso com anel de tricomas internamente, próximo à base da corola.

Chave para identificação das espécies de Palicourea do PEVRI

1. Inflorescências em cimeiras paniculiformes

2. Folhas com 12-15 nervuras secundárias de cada lado; panículas congestas; pedúnculo 7-14 cm compr.; flores pubescentes

3. P. macrobotrys

2. Folhas com 8-10 nervuras secundárias de cada lado; panículas laxas; pedúnculo 5-10 cm compr.; flores glabras

1. P. croceoides

1. Inflorescência em cimeiras corimbiformes

3. Corola glabra; sementes com superfície dorsal costada 2. P. fastigiata

3. Corola pubescente com glândulas no terço superior; sementes com superfície dorsal lisa 4. P. marcgravii

17.1. Palicourea croceoides Desv. ex Ham., Prodromus Plantarum Indiae Occidentalis: $29.1825 \equiv$ Psychotria crocea Sw., Nova Genera et Species Plantarum seu Prodromus: 44. 1788.

Figuras 77-80

Arbustos eretos, 1-2 m alt.. Ramos cilíndricos, glabros. Folhas pecioladas, pecíolo semicilíndrico, 0,5-1 cm compr, glabro; lâmina lanceolada, 7-13 × 2,5-6 cm, glabra, nervuras primária e secundárias proeminentes na superfície abaxial,
8-10 nervuras secundárias de cada lado, ápice acuminado, base aguda, margem inteira; estípulas persistentes, bipartidas, lanceoladas. Inflorescências em cimeiras paniculiformes, laxas, raque $6-10 \mathrm{~cm}$ compr., terminais, pedúnculo $5-10 \mathrm{~cm}$ compr., alaranjado; brácteas lanceoladas, 1-1,2 cm compr., bractéolas muito reduzidas, filiformes; flores pediceladas, pedicelo 5-8 $\mathrm{mm}$ compr., distílicas; cálice campanulado, amarelado, 2-4 mm compr., lobos triangulares, glabros, 0,6-1 mm compr.; corola tubulosa, gibosa, amarela, 1-1,2 cm compr. externamente glabra, internamente com anel de tricomas no terço basal, lobos triangulares, 2-3 mm compr.; estames inseridos na fauce ou no tubo da corola, inclusos ou exsertos; filetes semicilíndricos, 1-5 mm compr.; anteras lanceoladas; ovário bilocular, um óvulo por lóculo; disco nectarífero inteiro, $1 \mathrm{~mm}$ compr.; estilete cilíndrico, incluso ou exserto, 0,8-1,2 cm compr.; estigma bífido. Fruto drupáceo, globoso, preto, 5-7 × 4-6 $\mathrm{mm}$, cálice persistente; sementes plano-convexas, castanhas, superfície ventral sulcada longitudinalmente, superfície dorsal 4-costada.

Material examinado: BRASIL. Mato Grosso do Sul: Parque Estadual das Várzeas do Rio Ivinhema, 6-IX-2003, fl., Z.V. Pereira et al. 226 (DDMS); idem, 5-II-2005, fr., Z.V. Pereira et al. 983 (DDMS); idem, 26-II-2003, fr., Z.V. Pereira \& G. Lobcthenko 371 (DDMS); idem, 28-III-2004, fr., Z.V. Pereira et al. 524 (DDMS); idem, 13-XI-2004, fl., Z.V. Pereira et al. 921 (DDMS).

Material adicional examinado: BRASIL. BAHIA: Serra da Água de Rega, 26-II-1971, fr., H.S. Irwin et al. s.n. (UFG). GoiÁs: Goiânia, 30-I-1969, fl., J.A. Rizzo et al. 3558 (UFG); Goiânia, 8-XII-1968, fl., J.A. Rizzo et al. 3081 (UFG); Chapada dos Veadeiros, 19-III-1971, fr., H.S. Irwin s.n. (UFG); Serra Geral do Paraná, 22-III-1963, fl., fr., W.R. Anderson 7713 (UFG).

Essa espécie distribui-se do México até o Paraguai e Antilhas (Andersson 1992, Burger \& Taylor 1993). No Brasil, distribui-se pela região Amazônica, região Centro-Oeste e do Estado da Bahia até o Rio Grande do Sul (Andersson 1992). No PEVRI, ocorrem muitas populações amplamente distribuídas.

Palicourea croceoides caracteriza-se pela inflorescência em cimeiras paniculiformes, laxas, raque com menos de $10 \mathrm{~cm}$ de comprimento e pedúnculo com mais de $5 \mathrm{~cm}$ de comprimento. No PEVRI, essa espécie pode ser confundida com 
P. macrobotrys, contudo, diferencia-se desta pelas folhas menores, características da inflorescência e corola toda amarela. No PEVRI, floresce de outubro a dezembro e frutifica de dezembro a março.

17.2. Palicourea fastigiata Kunth, Nova Genera et Species Plantarum (quarto ed.) 3: 368. 1818 Figuras 81-83

Arbustos eretos, ca. 2-3,5 m alt. Ramos cilíndricos, glabros. Folhas pecioladas, pecíolo semicilíndrico, 1-2 cm compr., glabro; lâmina lanceolada, 5-12 × 2-3,5 cm, glabra, nervura primária e secundárias proeminentes na superfície abaxial, 8-10 nervuras secundárias de cada lado, ápice agudo, base aguda, margem inteira; estípulas persistentes, bipartidas, lanceoladas. Inflorescências em cimeiras corimbiformes, terminais, pedúnculo $2-8 \mathrm{~cm}$ compr., alaranjado; brácteas e bractéolas muito reduzidas, filiformes; flores pediceladas, pedicelo $0,5-1 \mathrm{~cm}$ compr., distílicas; cálice campanulado, amarelado, 2-3 mm compr., lobos triangulares, glabros, 1-1,5 mm compr.; corola tubulosa, gibosa, amarela nos $2 / 3$ basais passando a rosa-claro ou esbranquiçada no $1 / 3$ apical, 1,4-2,5 cm compr. externamente glabra, internamente com anel de tricomas no terço basal, lobos triangulares, 2-3 mm compr.; estames inseridos na fauce ou no tubo da corola, inclusos ou exsertos; filetes semicilíndricos, 1-5 mm compr.; anteras lanceoladas; ovário bilocular, um óvulo por lóculo; disco nectarífero inteiro, $1 \mathrm{~mm}$; estilete cilíndrico, incluso ou exserto, 1-1,5 cm compr.; estigma bífido. Fruto drupáceo, comprimido, elipsóide, 5-7 × 3-5 mm, cálice persistente; sementes plano-convexas, castanhas, superfície ventral sulcada longitudinalmente, superfície dorsal 4-5-costada.

Material examinado: BRASIL. Mato Grosso do Sul: Parque Estadual das Várzeas do Rio Ivinhema, 6-IX-2003, fl., Z.V. Pereira et al. 235 (DDMS); idem, 12-X-2006, fl., fr., Z.V. Pereira et al. 1666 (DDMS); idem, 6-IX-2003, fl., Z.V. Pereira et al. 228 (DDMS); idem, 28-III-2004, fr., Z. V. Pereira et al. 530 (DDMS).

Palicourea fastigiata distribui-se pelo Equador, Bolívia, Venezuela, Peru Colômbia e Brasil (Missouri Botanical Garden 2007). No PEVRI, ocorrem vários indivíduos distribuídos nas margens do rio Ivinhema. Pode ser facilmente confundida com P. marcgravii, contudo, diferencia-se desta pela corola glabra, róseo-clara ou esbranquiçada no terço apical e semente com a superfície dorsal costada. No PEVRI, floresce de setembro a dezembro e frutifica de novembro a abril.
17.3. Palicourea macrobotrys (Ruiz \& Pav.) DC., Prodromus Systematis Naturalis Regni Vegetabilis 4: $527.1830 \equiv$ Psychotria macrobotrys Ruiz \& Pav., Flora Peruviana 2: 57, t. 203, f.a. 1799.

Figuras 84, 85

Arbustos eretos, ca. $3 \mathrm{~m}$ alt.. Ramos cilíndricos, glabros. Folhas pecioladas, pecíolo semicilíndrico, 1-1,5 cm compr., glabro; lâmina lanceolada, $10-20 \times 4,5-8 \mathrm{~cm}$, esparsamente pubescente sobre as nervuras na superfície dorsal, nervuras primária e secundárias proeminentes na superfícies abaxial, 12-15 nervuras secundárias de cada lado, ápice acuminado, base aguda, margem inteira; estípulas persistentes, bipartidas, lanceoladas. Inflorescências em cimeiras paniculiformes, congestas, multifloras, terminais, raque $10-15 \mathrm{~cm}$ compr., pedúnculo 7-14 cm compr., alaranjado; brácteas e bractéolas, filiformes, reduzidas; flores pediceladas, pedicelo 5-8 mm compr, distílicas; cálice campanulado, 3-4 mm compr., lobos oval-triangulares, $1 \mathrm{~mm}$ compr., pubescentes; corola tubulosa, gibosa, tubo amarelo, lobos avermelhado, 1-1,5 cm compr., externamente pubescente, internamente com anel de tricomas na base, lobos triangulares, 1-2 mm compr.; estames inseridos na fauce ou no tubo da corola, inclusos ou exsertos; filetes semicilíndricos, 1-2 mm compr.; anteras lanceoladas; ovário bilocular, um óvulo por lóculo; disco nectarífero inteiro, $1 \mathrm{~mm}$ compr.; estilete cilíndrico, incluso ou exserto, $1-2 \mathrm{~cm}$ compr.; estigma bífido. Fruto drupáceo, comprimido, ovoide, 3-5 × 5-7 mm, cálice persistente; sementes plano-convexas, castanhas, superfície ventral sulcada longitudinalmente, superfície dorsal 4-constada.

Material examinado: BRASIL. Mato Grosso DO Sul: Parque Estadual das Várzeas do Rio Ivinhema, 12-X-2006, fl. fr., Z.V. Pereira et al. 1667 (DDMS); idem, 12-X-2006, fr., Z.V. Pereira et al. 1668 (DDMS).

Material adicional examinado: BRASIL. São PAULo: Campinas, Mata da Santa Genebra, 9-IV-1992, fl., fr., Patto et al. (UEC); Bauru, Jardim Botânico, 9-VII-1997, fl., M.H.O. Pinheiros 346 (UEC); Pindorama, Estação Experimental do IAC, 15-IV-1994, fl., V.C. Souza et al. 5750 (UEC). ParanÁ: Iguaçu, 18-IX-1979, fr., G.J. Shepherd 60993 (UEC).

Palicourea macrobotrys distribui-se pela Colômbia, Bolívia, Peru e Brasil (Andersson 1992, Delprete et al. 2005). No Brasil, ocorre nos Estados de Mato Grosso, Goiás e Minas Gerais, e da Bahia até o Rio Grande do Sul (Andersson 1992). No PEVRI, 


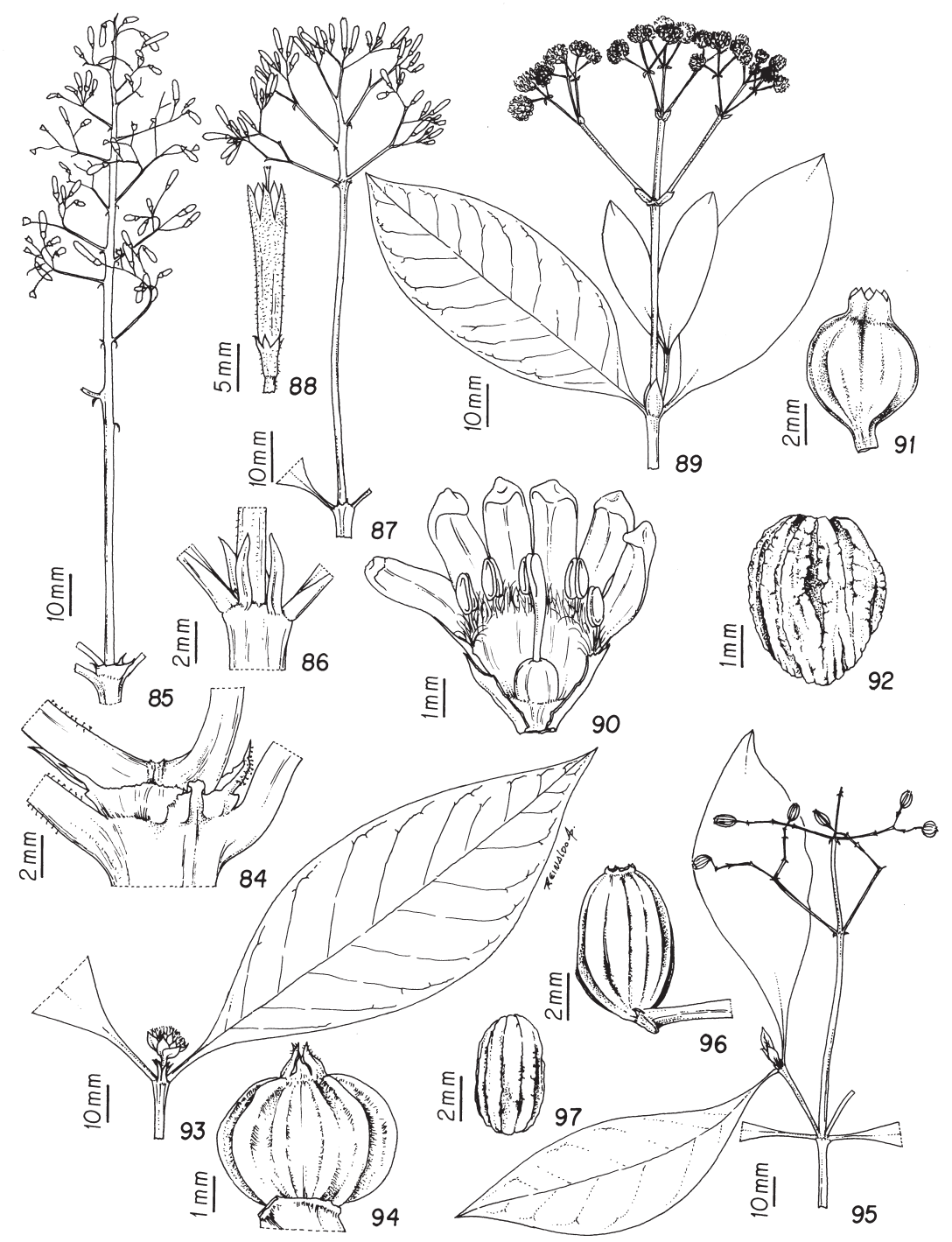

Figuras 84-97. Espécies de Rubiaceae do Parque Estadual das Várzeas do Rio Ivinhema, MS, Brasil. 84-85. Palicourea macrobotrys (Z.V. Pereira et al. 1667). 84. Detalhe da estípula bipartida. 85. Inflorescência em cimeira paniculiforme. 86-88. Palicourea marcgravii (Z.V. Pereira \& G. Lobtchenko 371). 86. Estípulas bipartidas lanceoladas. 87. Inflorescência em cimeira corimbiforme. 88. Detalhe da flor. 89-90. Psychotria anceps (Z.V. Pereira et al. 255, Z.V. Pereira \& G. Lobtchenko 433). 89. Ramo com inflorescência em dicásio composto e estípulas inteiras. 90. Detalhe da flor dissecada. 91. Fruto drupáceo, subgloboso, multissulcado. 92. Detalhe da semente. 93-94. Psychotria brachybotrya (Z.V. Pereira \& G. Lobtchenko 352, Z.V. Pereira et al. 480). 93. Inflorescência em cimeira glomeriforme, flores envolvidas por brácteas e bractéolas. 94. Fruto drupáceo globoso, multissulcado. 95-97. Psychotria carthagenensis (Z.V. Pereira et al. 923). 95. Detalhe do ramo evidenciando as estípulas inteiras e inflorescência com frutos. 96. Fruto drupáceo elipsóide, multissulcado. 97. Detalhe da semente.

Figures 84-97. Rubiaceae species of the Parque Estadual das Várzeas do Rio Ivinhema, Mato Grosso do Sul State, Brazil. 84-85. Palicourea macrobotrys (Z.V. Pereira et al. 1667). 84. Detail of bipartite stipule. 85. Paniculiform, cyme inflorescence . 86-88. Palicourea marcgravii (Z.V. Pereira \& G. Lobtchenko 371). 86. Lanceolate, bipartite stipules. 87. Corymbiform, cyme inflorescence. 88. Detail of the flower. 89-90. Psychotria anceps (Z.V. Pereira et al. 255, Z.V. Pereira \& G. Lobtchenko 433). 89. Branch with composite dichasium inflorescence, and entire stipules. 90. Detail of dissected flower. 91. Drupaceous, subglobose, multi-furrowed fruit. 92. Detail of seed. 93-94. Psychotria brachybotrya (Z.V. Pereira \& G. Lobtchenko 352, Z.V. Pereira et al. 480). 93. Glomerule, cyme inflorescence, flowers enveloped by bracts and bracteoles. 94. Drupaceous, subglobose, multi-furrowed fruit. 95-97. Psychotria carthagenensis (Z.V. Pereira et al. 923). 95. Detail of branch, showing the entire stipules and inflorescence with fruits. 96. Ellipsoidal drupaceous, multi-furrowed fruit. 97 . Detail of seed.. 
foram amostrados poucos indivíduos, distribuídos na margem direita do rio Ivinhema, sendo esta a primeira ocorrência para o Estado do Mato Grosso do Sul.

No PEVRI, essa espécie pode ser reconhecida pelas folhas grandes (10-20 cm de comprimento), com nervuras secundárias 12-15 de cada lado, inflorescência em cimeiras paniculiformes, congestas, multifloras, raque com mais de $10 \mathrm{~cm}$ de comprimento e corola pubescente, amarela com lobos avermelhados. Floresce de setembro a dezembro e frutifica de novembro a junho.

17.4. Palicourea marcgravii A. St.-Hil., Pl. Remarq. du Brésil 22: 231. 1824.

Figuras 86-88

Arbustos eretos, ca. $3 \mathrm{~m}$ alt.. Ramos cilíndricos, glabros. Folhas pecioladas, pecíolo semicilíndrico, 3-6 mm compr., glabro; lâmina lanceolada, $8-11 \times 2-3,5 \mathrm{~cm}$, esparsamente pubescente sobre nervuras na superfície dorsal, nervura primária proeminente em ambas as superfícies, ápice agudo a acuminado, base obtusa ou truncada, margem inteira; estípulas persistentes, bipartidas, lanceoladas. Inflorescências em cimeiras corimbiformes, terminais, pedúnculo 3-5 cm compr., avermelhado; muitas brácteas reduzidas; flores pediceladas, pedicelo 5-8 mm compr., distílicas; cálice campanulado, avermelhado, 2-3 mm compr., lobos triangulares ou cuneados, pubescentes; corola tubulosa, gibosa, amarela nos $2 / 3$ basais passando a lilás no $1 / 3$ apical, 1,7-2,5 cm compr., externamente pubescente, com glândulas no terço superior, internamente com anel de tricomas no terço basal, lobos triangulares, reflexos no ápice, 2,5-4 $\mathrm{mm}$ compr.; estames inseridos na fauce ou no tubo da corola, inclusos ou exsertos; filetes semicilíndricos, 1-2,5 mm compr.; anteras lanceoladas; ovário bilocular, um óvulo por lóculo; disco nectarífero inteiro; estilete cilíndrico, incluso ou exserto, 10-22 mm compr.; estigma bífido. Fruto drupáceo, comprimido, ovoide, 3-5 × 2-3,5 mm, cálice persistente; sementes plano-convexas, castanhas, superfície ventral sulcada longitudinalmente, superfície dorsal lisa.

Material examinado: BRASIL. Mato Grosso Do Sul: Parque Estadual das Várzeas do Rio Ivinhema, 17-I-2002, fl., Z.V. Pereira et al. 49 (DDMS); idem, 26-XII-2003, fl., fr., Z.V. Pereira \& G. Lobtchenko 371 (DDMS).

Material adicional examinado: BRASIL. PARANÁ: Ipiranga, 27-XI-1987, fl., A.C. Carvi 2507 (CGMS). Minas Gerais: Viçosa, trilha lateral, 6-XI-2001, fl., Z.V.
Pereira \& G.E. Valente 42 (VIC); Viçosa, trilha principal, 11-III-2002, fr., Z.V. Pereira \& G.E. Valente 74 (VIC).

Palicourea marcgravii é uma espécie amplamente distribuída no Brasil, exceto no extremo Sul e no sertão do Nordeste (Kissmann \& Groth 2000). No PEVRI, ocorrem alguns indivíduos na mata ciliar do lado direito das margens do rio Ivinhema.

Essa espécie caracteriza-se pelas inflorescências terminais em cimeiras corimbiformes com pedúnculo avermelhado de 3-4 $\mathrm{cm}$ de comprimento, flores amarelas nos $2 / 3$ basais e lilás no $1 / 3$ apical, pubescente, com pontuações nos lobos e semente com superfície dorsal lisa. No PEVRI, floresce de setembro a dezembro e frutifica de janeiro a abril.

18. Psychotria L., Syst. Nat. 2: 929, 1122, 1264. 1759. Nom. Conserv.

Psychotria é um gênero pantropical, e constitui um dos maiores gêneros de angiospermas, com cerca de 1.000 espécies (Taylor 2007). Segundo Taylor (1994, 2007), são conhecidas cerca de 500 espécies neotropicais. No Brasil, distribui-se por quase todo o território nacional (Andersson 1992). No PEVRI, é o gênero que apresenta a maior diversidade, estando representado por 10 espécies amplamente distribuídas.

As espécies desse gênero caracterizam-se pelas inflorescências com pedúnculo verde ou branco, nunca de outras cores, corola branca ou amarela, tubo da corola reto, não giboso, com anel de tricomas internamente na região mediana do tubo, nunca na base. Psychotria e Palicourea são gêneros muito próximos; a distinção entre ambos foi apresentada nos comentários sobre Palicourea.

Chave para identificação das espécies de Psychotria do PEVRI

1. Flores tetrâmeras 6. P. leiocarpa

1. Flores pentâmeras

2. Estípulas inteiras

3. Inflorescência em cimeiras paniculiformes 4. P. carthagenensis

3. Inflorescência em cimeiras corimbiformes ou dicásio composto

4. Folhas 10-15 cm compr.; nervuras secundárias 7-10 de cada lado, sem domácias; inflorescência em dicásio composto; corola branca .......... 1. P. anceps

4. Folhas 5-8 cm compr.; nervuras secundárias 5-6 de cada lado, com domácias saculiformes; inflorescências em cimeiras corimbiformes laxas; corola amarela .................................... 3. P. capillacea 
2. Estípulas bipartidas

5. Inflorescência em cimeiras paniculiformes

6. Folhas 5-8 cm compr.; 5-7 nervuras secundárias de cada lado; pedúnculo da inflorescência verde; fruto preto; semente 4-costada.

\section{P. tenerior}

6. Folhas 8-15 cm compr.; 6-8 nervuras secundárias de cada lado; pedúnculo da inflorescência vináceo; fruto branco; semente 5-costada 5. P. deflexa

5. Inflorescências em cimeiras 3-4-floras, glomeriformes ou capituliformes

7. Subarbusto com até $50 \mathrm{~cm}$ alt.; folhas com margem crenada; inflorescências 3-4-floras 8. P. prunifolia

7. Arbusto com mais de $80 \mathrm{~cm}$ alt.; folhas com margem inteira; inflorescências multifloras

8. Folhas com 20 pares ou mais de nervuras secundárias, perpendiculares à nervura principal ......... 10. P. vellosiana

8. Folhas com até 15 pares de nervuras secundarias, oblíquas à nervura principal

9. Folhas glabras; inflorescência em cimeiras glomeriformes; brácteas e bractéolas paleáceas; corola branca; fruto preto

2. P. brachybotrya

9. Folhas hirsutas; inflorescência em cimeiras capituliformes; duas brácteas foliáceas vermelhas; flores amarelas; fruto azul

\section{P. poeppigiana}

18.1. Psychotria anceps Kunth, Nova Genera et Species Plantarum (quarto ed.) 3: 360. 1818.

Figuras 89-92

Arbusto, 1-2 m alt.. Ramos cilíndricos, passando a quadrangular na região apical, glabros. Folhas pecioladas, pecíolo semicilíndrico, 0,6-1 cm compr.; lâmina lanceolada, 10-15 × 2-5 cm, verde amarelada, cartácea, glabra, nervuras primária e secundárias proeminentes na superfície abaxial, 7-10 nervuras secundárias de cada lado, sem domácias, ápice agudo, base aguda, margem inteira; estípulas inteiras, caducas, $10 \mathrm{~mm}$ compr., ápice agudo. Inflorescências em dicásios compostos, terminais, pedunculadas, pedúnculo verde 3-6 cm compr.; brácteas e bractéolas lanceoladas, reduzidas; flores sésseis, pentâmeras, distílicas; cálice 1,5 mm compr., campanulado, lobos triangulares, 0,5 $\mathrm{mm}$ compr.; corola campanulada, branca, 5-10 mm compr., externamente glabra, internamente com anel de tricomas na região mediana, lobos lanceolados, 3-4 mm compr.; estames inseridos no tubo ou na fauce da corola, inclusos ou exsertos; filetes semicilíndricos 1-2 mm compr.; anteras oblongas; ovário bilocular, um óvulo por lóculo; disco nectarífero inteiro, $1 \mathrm{~mm}$ compr.; estilete cilíndrico, incluso ou exserto, 4-13 mm compr., estigma bífido. Fruto drupáceo, subgloboso, multissulcado, preto, 3-5 × 2-4 $\mathrm{mm}$, cálice persistente; semente plano-convexa, superfície ventral plana com sulco longitudinal, superfície dorsal 6-costada.

Material examinado: BRASIL. Mato Grosso DO Sul: Parque Estadual das Várzeas do Rio Ivinhema, 6-IX-2004, fl, Z.V. Pereira et al. 255 (DDMS); idem, 13-III-2004, fr., Z.V. Pereira \& G. Lobtchenko 433 (DDMS); idem, 27-VI-2004, fr., Z.V. Pereira et al. 685 (DDMS).

Material adicional examinado: BRASIL. Distrito FEDERAL: Reserva Ecológica do IBGE, 14-II-1985, fr., R.C. Mendonça \& M. Ribeiro s.n. (UEC); Bacia do Rio Bartolomeu, 13-X-1983, fl., R.C. Mendonça 284 (UEC); Picada R-6 7-XII-1977, fl., fr., E.P. Hernger et al. s.n. (UEC).

Psychotria anceps distribui-se pelo Equador, Guianas, Colômbia, Bolívia e Brasil (Andersson 1992, Missouri Botanical Garden 2007). No Brasil ocorre nos Estados da Amazônia, Goiás, Distrito Federal, Bahia, Rio de Janeiro e São Paulo (Missouri Botanical Garden 2007). No PEVRI, foram amostrados vários indivíduos próximos à mata paludícola, sendo esta a primeira ocorrência registrada para o Estado do Mato Grosso do Sul.

Essa espécie é facilmente confundida com $P$. carthagenensis devido às estípulas grandes $\mathrm{e}$ inteiras e os frutos vermelho. Contudo, as folhas verde-amareladas, cartáceas e inflorescências em dicásios compostos de $P$. anceps constituem características diagnósticas importantes para distinção de ambas as espécies. No PEVRI, floresce de setembro a dezembro e frutifica de novembro a julho.

18.2. Psychotria brachybotrya Mull. Arg., Flora Brasiliensis 6(5): 327. 1881.

Figuras 93, 94

Arbusto, ca. $1 \mathrm{~m}$ alt. Ramos cilíndricos glabros. Folhas pecioladas, pecíolo semicilíndrico, 
0,5-1 cm compr.; lâmina elíptico-lanceolada, 10-18 × 4-7 cm, glabra, nervuras primária e secundárias proeminentes em ambas as faces, 7-8 nervuras secundárias de cada lado, ápice acuminado, base aguda, margem inteira; estípulas bipartidas, persistentes, internamente pilosa. Inflorescência em cimeiras glomeriformes terminais, pedunculadas, pedúnculo 1,8-2 $\mathrm{cm}$ compr., verdes durante a floração, vináceo na frutificação; brácteas e bractéolas paleáceas; flores sésseis, pentâmeras, distílicas; cálice com lobos lanceolados, ciliados, $3 \mathrm{~mm}$ compr.; corola tubular, branca, 6-7 mm compr., externamente glabra, internamente com anel de tricomas na região mediana, lobos triangulares, 1,5-2 mm compr., reflexo na flor em antese; estames inseridos no tubo ou na fauce da corola, inclusos ou exsertos; filetes semicilíndricos 1-3 mm compr.; anteras lanceoladas; ovário bilocular, um óvulo por lóculo; disco nectarífero bipartido; estilete cilíndrico, incluso ou exserto, 3-6 mm compr., estigma bífido. Fruto drupáceo, globosos, multissulcado, preto, 4-8,5 × 4-8 mm, cálice persistente; semente plano convexa, superfície ventral plana, sulco longitudinal, superfície dorsal 5-costada.

Material examinado: BRASIL. Mato Grosso do Sul: Parque Estadual das Várzeas do Rio Ivinhema, 26-XII-2003, fl., Z.V. Pereira \& G. Lobtchenko 352 (DDMS); idem, 27-III-2004, fr., Z.V. Pereira et al. 480 (DDMS); idem, 5-II-2005, fr., Z.V. Pereira et al. 984 (DDMS).

Segundo Andersson (1992), P. brachybotrya, distribui-se do México até a região Amazônica. Lombardi \& Gonçalves (2000) também registraram essa espécie para o Estado de Minas Gerais. Sua ocorrência no PEVRI constitui o primeiro registro para o Estado do Mato Grosso do Sul, tendo sido coletados vários indivíduos, distribuídos nos fragmentos de transição próximos a entrada principal do Parque.

Essa espécie diferencia-se das demais espécies de Psychotria amostradas no PEVRI, pelas folhas grandes, inflorescência em glomérulos terminais, brácteas e bractéolas paleáceas e semente com superfície 5-costada. Floresce de outubro a dezembro e frutifica de janeiro a abril.

18.3. Psychotria capillacea (Mull. Arg.) Standl., Field Museum of Natural History, Botanical Series 22(3): $202.1940 \equiv$ Mapouria capillacea Mull. Arg., Flora Brasiliensis 6(5): 405. 1881.

Figuras 98-101

Arbustos, ca. $1 \mathrm{~m}$ alt. Ramos cilíndricos, glabros. Folhas pecioladas, pecíolos semicilíndricos,
0,3-0,5 cm compr., glabros; lâmina elíptico-lanceolada, $5-8 \times 1,5-2,5 \mathrm{~cm}$, glabras, nervura primária proeminente em ambas as faces, 5-6 nervuras secundárias de cada lado, domácias saculiformes, ápice acuminado, base aguda, margem inteira; estípulas inteiras, caducas, triangulares, ciliadas, ápice acuminado. Inflorescências em cimeiras corimbiformes, laxas, terminais, pedúnculo 3-4 cm compr.; brácteas e bractéolas reduzidas, lanceoladas; flores pediceladas, pedicelo 2-4 mm compr., pentâmeras, distílicas; cálice 1-2 mm compr., lobos triangulares; corola hipocrateriforme, amarela, $15 \mathrm{~mm}$ compr., externamente glabra, internamente com anel de tricomas na região mediana, lobos lanceolados, 1-1,5 mm compr., reflexos na flor em antese; estames inserido na fauce ou no tubo da corola, inclusos ou exsertos; filete semicilíndrico 1-3 mm compr., anteras lanceoladas; ovário bilocular, um óvulo por lóculo; disco nectarífero inteiro, 4-6 mm compr.; estilete cilíndrico, incluso ou exserto 3-4 mm compr.; estigma bífido. Fruto drupáceo, globoso, vermelho, 5-8 × 4-6 mm, cálice persistente; sementes plano convexas, superfície ventral plana, com sulco longitudinal, superfície dorsal 4-costada.

Material examinado: BRASIL. Mato Grosso do Sul: Parque Estadual das Várzeas do Rio Ivinhema, 27-XII-2003, fl., Z.V. Pereira \& G. Lobtchenko 402 (DDMS); idem, 6-IX-2003, fr., fl., Z.V. Pereira et al. 263 (DDMS).

Material adicional examinado: BRASIL. São PAULO: Adamantina, 5-IX-1995, fr., L.C. Bernacci et al. 1936 (IAC). Paraná: Porto Rico, Canal Cortado, 11-X-1992, fl., M.C. Souza \& A.C. Correto 2 (IAC); Porto Rico, Canal Cortado, 18-IV-1994, fr., M. Curti 37 (IAC).

Psychotria capillacea distribui-se pelo Brasil, nos Estados da Amazônia, Mato Grosso do Sul e Paraná, além do Paraguai e Argentina (Andersson 1992). No PEVRI, ocorrem vários indivíduos distribuídos pela mata ciliar da margem direita do rio Ivinhema. Essa espécie caracteriza-se pelo porte pequeno, estípulas inteiras, folhas glabras com domácias, inflorescência em cimeiras corimbiformes, laxas, flores pequenas, amarelas e frutos vermelhos. No PEVRI, floresce de setembro a dezembro e frutifica de outubro a julho.

18.4. Psychotria carthagenensis Jacq., Enum. P1. Carib.: 16. 1760.

Figuras 95-97

Arbustos, ca. $3 \mathrm{~m}$ alt. Ramos cilíndricos, glabros. Folhas pecioladas, pecíolo semicilíndrico 
1-1,5 cm compr., glabro; lâmina elíptico-lanceolada, 8-18 × 5-8 cm, glabra, nervuras primária e secundárias proeminentes na superfície dorsal, 7-9 nervuras secundárias de cada lado, ápice agudo, base atenuada, margem inteira; estípulas caducas, inteiras, concrescidas somente na base, 1,5-2 cm compr., oblanceolada. Inflorescências pedunculadas, pedúnculos $4-8 \mathrm{~cm}$ compr., verdes, em cimeiras paniculiformes, terminais; brácteas triangulares caducas; flores sésseis, pentâmeras, distílicas; cálice $0,5 \mathrm{~mm}$ compr., truncado, pubescente; corola campanulada, branca, 5-7 $\mathrm{mm}$ compr., externamente pubescente, internamente com anel de tricomas na região mediana do tubo, lobos levemente reflexos na flor em antese, com ápices recurvados; estames inseridos na fauce ou no tubo da corola, inclusos ou exsertos; filetes semicilíndricos, 0,8-2 mm compr.; anteras elipsoides; ovário bilocular, um óvulo por lóculo; disco nectarífero inteiro; estilete cilíndrico, incluso ou exserto, 2,5-5 mm compr.; estigma bífido. Fruto drupáceo, elipsóide, multissulcado, vermelho, 6-8 × 4-6 mm, cálice persistente; sementes plano-convexas, castanho-escuras, superfície ventral plana com profundo sulco longitudinal, superfície dorsal 4-costada.

Material examinado: BRASIL. Mato Grosso DO Sul: Parque Estadual das Várzeas do Rio Ivinhema, 6-IX-2003, fr., Z.V. Pereira et al. 225 (DDMS); idem, 11-IX-2004, fr., Z.V. Pereira et al. 824 (DDMS); idem, 13-XI-2004, fl., Z.V. Pereira et al. 908 (DDMS); idem, 13-XI-2004, fr., Z.V. Pereira et al. 923 (DDMS).

Material adicional: BRASIL. BAHIA: Itabuna, 6-VI-1979, fr., L.A. Mattos et al. 412 (UFG); Ilhéus, 27-V-1979, fr., L.A. Mattos et al. 513 (UFG). Mато Grosso do Sul: Corumbá, 25-IV-1993, fr., Masão s.n. (CGMS); Campo Grande, 9-III-1992, fl., Alunos de Biologia s.n. (CGMS); idem, 5-XII-1997, fl., A.P.A. Araújo et al. s.n. (CGMS); Corumbá, 3-VII-1996, fl., M. Eugênia s.n. (CGMS).

Psychotria carthagenensis distribui-se nos Estados Unidos, México, América do Sul, Antilhas e na América Central, principalmente, na costa do pacífico em elevações de 0-1.400 m.s.m., em florestas úmidas de clima tropical e equatorial (Burger \& Taylor 1993). No Brasil, ocorre nas regiões Norte, Sudeste e Centro-Oeste (Andersson 1992). No PEVRI, está representada por muitos indivíduos, distribuídos por todo o interior do Parque. No campo, P. carthagenensis pode ser reconhecida pelas estípulas inteiras, grandes e oblanceoladas e frutos multissulcados, vermelhos na maturidade. No PEVRI, floresce de agosto a dezembro e frutifica de setembro a julho.
18.4. Psychotria deflexa DC., Prodromus Systematis Naturalis Regni Vegetabilis 4: 510. 1830. Figuras 102-106

Arbusto, 1-2 m alt. Ramos cilíndricos, glabros. Folhas pecioladas, pecíolo semicilíndrico, 0,5-0,8 cm compr.; folhas jovens vinácea; lâmina linear, $8-15 \times 2-5,5 \mathrm{~cm}$, glabra, nervuras primária e secundárias proeminentes na superfície abaxial, 6-8 nervuras secundárias de cada lado, ápice acuminado, base aguda, margem inteira; estípulas bipartidas, persistentes, lanceoladas, 6-8 $\mathrm{mm}$ compr. Inflorescência em cimeiras paniculiformes terminais, pedúnculo 1-4 cm compr., vináceo; bractéolas reduzidas; flores pediceladas, pedicelo 3-5 $\mathrm{mm}$ compr., pentâmeras, distílicas; cálice 1,5-2 mm compr., lobos triangulares, $0,5-0,8 \mathrm{~mm}$ compr.; corola tubular, branca, 4-5 mm compr., externamente glabra, internamente com anel de tricomas na região mediana, lobos triangulares, 1,5-2 mm compr., reflexo na flor em antese; estames inseridos no tubo ou na fauce da corola, inclusos ou exsertos; filetes semicilíndricos 1-3 mm compr.; anteras lanceoladas; ovário bilocular, um óvulo por lóculo; disco nectarífero bipartido; estilete cilíndrico, incluso ou exserto, 2-4 mm compr., estigma bífido. Fruto drupáceo, globoso, branco, 5-8,5 × 4-8 mm, cálice persistente; sementes plano convexas, superfície ventral plana, sulco longitudinal, superfície dorsal 5-costada.

Material examinado: BRASIL. Mato Grosso do Sul: Parque Estadual das Várzeas do Rio Ivinhema, 14-IX-2004, fl., Z.V. Pereira et al. 937 (DDMS); idem, 5-II-2005, fr., Z.V. Pereira et al. 985 (DDMS); idem, 4-I-2007, fr., Z.V. Pereira et al. 1679 (DDMS).

Material adicional examinado: BRASIL. BAHIA: Ilhéus, 9-VI-1979, fr., S. A. Mori 11905 (UFG); Santa Cruz de Cabrália, 16-V-1979, fr., S.A. Mori et al. 11855 (UFG); Uruçuca, 9-VI-1979, fl., fr., S. Mori 11907 (UFG). GoIÁs: Goiânia, 23-XII-1970, J.A. Rizzo 6945 (UFG); Goiânia, 26-I-1971, fl., J.A. Rizzo 6964 (UFG).

Psychotria deflexa distribui-se do México até a Argentina (Andersson 1992). No Brasil, ocorre em quase todos os Estados brasileiros (Andersson 1992). No PEVRI, ocorrem vários indivíduos distribuídos pela mata ciliar da margem direita do rio Ivinhema. $P$. deflexa é de fácil reconhecimento pelas folhas jovens vináceas, glabras, estípulas bipartidas, inflorescências em cimeiras paniculiformes, terminais, pedúnculo vináceo, corola branca com lobos reflexos na flor em antese, frutos globosos, brancos e semente com a superfície dorsal 5-costada. Floresce de novembro a dezembro e frutifica de dezembro a março. 


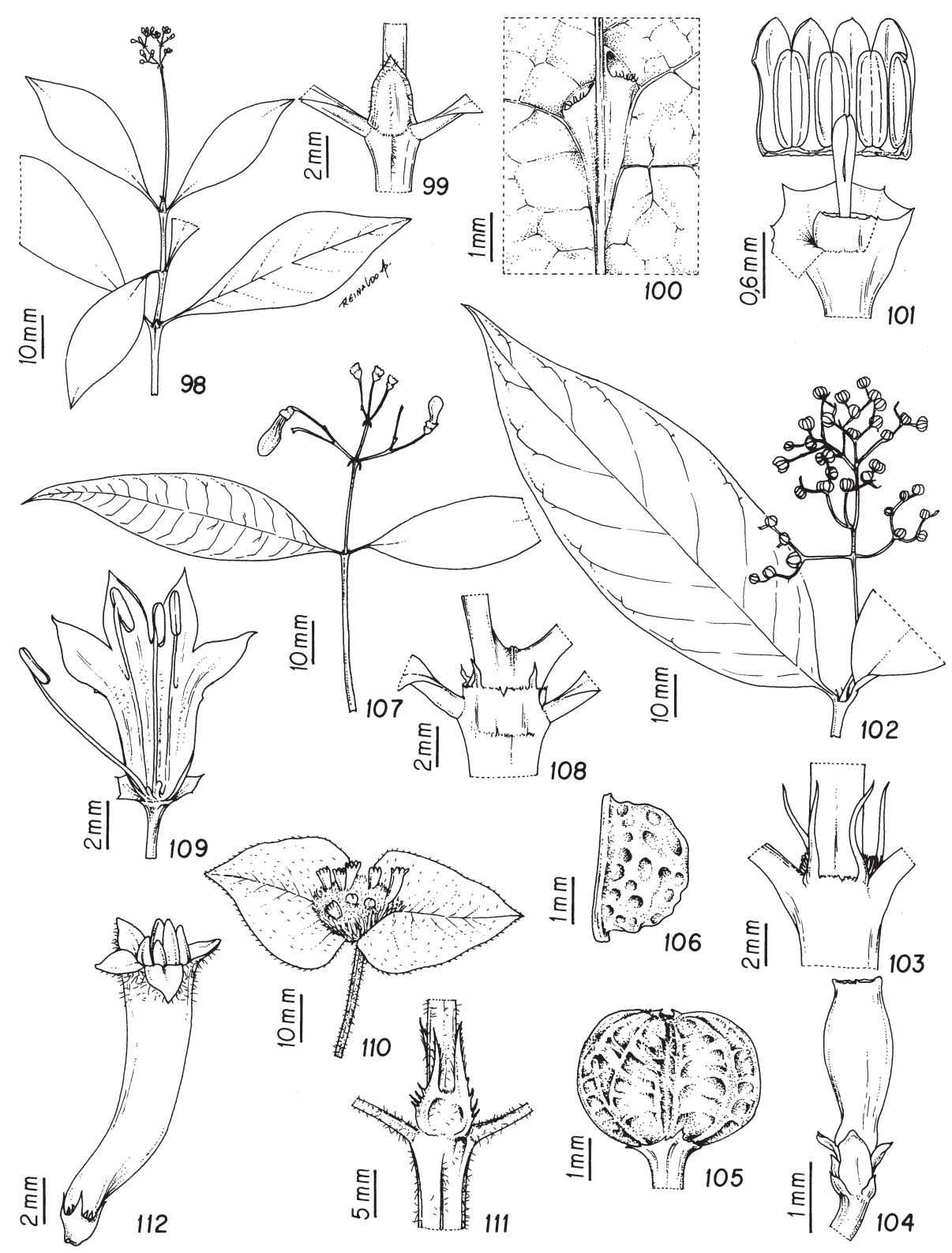

Figuras 98-112. Espécies de Rubiaceae do Parque Estadual das Várzeas do Rio Ivinhema, MS, Brasil. 98-101. Psychotria capillacea (Z.V. Pereira \& G. Lobtchenko 402). 98. Detalhe do ramo e inflorescência em cimeira corimbiforme, laxa. 99. Estípulas inteiras ciliadas. 100. Folhas com domácias saculiformes. 101. Detalhe do botão floral dissecado. 102-106. Psychotria deflexa (Z.V. Pereira et al. 937, 985). 102. Detalhe do ramo com folhas e frutos. 103. Estípulas bipartidas lanceoladas. 104. Detalhe da flor. 105. Fruto drupáceo globoso. 106. Detalhe da semente. 107-109. Psychotria leiocarpa (Z.V. Pereira et al. 1670). 107. Ramo com folhas e inflorescência em cimeira corimbiforme. 108. Estípulas bipartidas. 109. Detalhe da flor dissecada sem o ovário. 110-112. Psychotria poeppigiana (Z.V. Pereira et al. 1612). 110. Detalhe da inflorescência capituliforme com brácteas foliáceas. 111. Estípulas bipartidas hirsutas. 112. Detalhe da flor levemente zigomorfa.

Figures 98-112. Rubiaceae species of the Parque Estadual das Várzeas do Rio Ivinhema, Mato Grosso do Sul State, Brazil. 98-101. Psychotria capillacea (Z.V. Pereira \& G. Lobtchenko 402). 98. Detail of branch and corymbiform, cyme, lax inflorescence. 99. Entire, ciliate stipules. 100. Leaves with saculiform domatia. 101. Detail of dissected flower bud. 102-106. Psychotria deflexa (Z.V. Pereira et al. 937, 985). 102. Detail of branch with leaves and fruits. 103. Lanceolate, bipartite stipules. 104. Detail of flower. 105. Globose, drupaceous fruit. 106. Detail of seed. 107-109. Psychotria leiocarpa (Z.V. Pereira et al. 1670). 107. Branch with leaves and a corymbiform, cyme inflorescence. 108. Bipartite stipules. 109. Detail of a dissected flower, without the ovary. 110-112. Psychotria poeppigiana (Z.V. Pereira et al. 1612). 110. Detail of capituliform inflorescence, with foliaceous bracts. 111. Bipartite, hirsute stipules 112. Detail of slightly zygomorphic flower. 
18.5. Psychotria leiocarpa Cham. \& Schltdl., Linnaea 4: 22.1829.

Figuras 107-109

Arbustos, 1,5 m alt. Ramos cilíndricos, glabros. Folhas pecioladas, pecíolo semicilíndrico, 0,3-0,5 cm compr.; lâmina lanceolada, 4-9,5 × 1-2,5 cm, glabra, nervura primária proeminente em ambas as faces, 10-14 nervuras secundárias de cada lado, ápice acuminado, base aguda, margem ondulada; estípulas bipartidas, com tricomas, ápice acuminado. Inflorescências em cimeiras corimbiformes, terminais, pedunculadas, pedúnculo 1-3 cm compr.; flores pediceladas, pedicelo 0,5-1 cm compr., tetrâmeras, distílicas; cálice $2 \mathrm{~mm}$ compr., lobos triangulares; corola tubulosa, branca, 0,8-1,5 cm compr., externamente glabra, internamente com anel de tricomas na região mediana, lobos triangulares, 4-8 mm compr., reflexo na flor em antese; estames inseridos na fauce ou no tubo da corola, inclusos ou exsertos; filete semicilíndricos, 2-4 mm compr.; anteras lanceoladas; ovário bilocular, um óvulo por lóculo; disco nectarífero bipartido; estilete cilíndrico, incluso ou exserto, 5-8 mm compr.; estigmas bífido. Fruto drupáceo, subglobosos, azul, $6-10 \times 0,5-0,8 \mathrm{~mm}$, cálice persistente; sementes plano-convexas, castanhas, superfície ventral plana, superfície dorsal 4-costada.

Material examinado: BRASIL. Mato Grosso do Sul: Parque Estadual das Várzeas do Rio Ivinhema, 12-X-2006, fl., Z.V. Pereira et al. 1670 (DDMS); idem, 4-I-2007, fr., Z.V. Pereira et al. 1678 (DDMS).

Material adicional examinado: BRASIL. BAHIA: Camamu, 15-VI-1979, fr., L.A. Mattos, et al. 510 (UFG). Goiás: Corumbá, 13-III-2002, fr., D. Fagi 4713 (UFG). Mato Grosso do Sul: Bonito, 3-XII-1998, fl., V.J. Pott 3837 (CGMS). Minas Gerais: Viçosa, X-1994, fl., J.A.A.M. Neto 2161 (VIC).

Psychotria leiocarpa distribui-se dos Estados da Bahia e Minas Gerais até o Rio Grande do Sul, bem como no Mato Grosso do Sul e Paraguai (Andersson 1992, Delprete et al. 2005). No PEVRI, foram amostrados vários indivíduos distribuídos na mata ciliar da margem direita do rio Ivinhema.

Das espécies de Psychotria amostradas no PEVRI, $P$. leiocarpa é a única que apresenta flores tetrâmeras. Além disso, as folhas com margem ondulada, flores brancas, frutos azuis e sementes com a superfície dorsal 4-costada constituem características diagnósticas importantes. No PEVRI, floresce de outubro a dezembro e frutifica de dezembro a março.
18.7. Psychotria poeppigiana Mull. Arg., Flora Brasiliensis 6(5): 370. 1881.

Figuras 110-112

Arbusto, ca. 1,5 m alt. Ramos cilíndricos, hirsutos. Folhas pecioladas, pecíolos semicilíndricos, 1,5-2 cm compr., hirsutos; lâmina elíptico-lanceolada, $12-17 \times 4,5-5,5 \mathrm{~cm}$, nervuras primária e secundárias proeminentes na superfície abaxial, 10-12 nervuras secundárias de cada lado, oblíquas, a primária hirsuta, ápice acuminado, base aguda a assimétrica, margem inteira; estípulas bipartidas, persistentes, hirsutas. Inflorescências em cimeiras capituliformes, multifloras, terminais, 2 brácteas foliáceas, avermelhadas, hirsutas, ovais, $2-5 \times 2,5-3,5 \mathrm{~cm}$, bractéolas lanceoladas, $1 \mathrm{~cm}$ compr.; flores sésseis, pentâmeras, distílicas, levemente zigomorfas; cálice 2-5 mm compr., ciliado; corola tubular, amarela, 1-1,8 cm compr., hirsuta, lobos triangulares 2-7 mm compr., ciliados; estames inseridos na fauce ou no tubo da corola, inclusos ou exsertos; filete semicilíndrico, 1-6 mm compr.; anteras lanceoladas; ovário bilocular, um óvulo por lóculo; disco nectarífero inteiro, 2-3,5 mm compr.; estilete cilíndrico, incluso ou exserto, $0,5-1,2 \mathrm{~cm}$ compr., estima bífido. Fruto drupáceo, obovóide, azul, 1-2 × 0,5-1 cm, cálice persistente; sementes plano convexas.

Material examinado: BRASIL. Mato Grosso Do Sul: Parque Estadual das Várzeas do Rio Ivinhema, 12-X-2006, fl., Z.V. Pereira et al. 1612 (DDMS); idem, 12-X-2006, fl., fr., Z.V. Pereira et al. 1613 (DDMS).

Material adicional examinado: BRASIL. MAto Grosso do Sul: Gaúcho do norte, 14-III-2001, fl., fr., N.M. Ivanonskas 4477 (EUC); Rio Brilhante, 14-VIII-1990, fr., G. Hatschbach 24642 (UEC). МАто Grosso: Chapada dos Guimarães, 18-II-1997, fl., fr., A.G. Nave et al. 1035 (UEC). GoIÁs: Rio Verde, 19-IV-1978, fl., G.J. Shepherd et al. 7442 (UEC).

Psychotria poeppigiana distribui-se no México, América Central, Brasil e Bolívia (Burger \& Taylor 1993). No Brasil, distribui-se por quase todos os Estados brasileiros (Andersson 1992). No PEVRI, foram amostrados poucos indivíduos distribuídos dentro da mata paludícola.

No PEVRI, essa espécie é de fácil reconhecimento, pois é a única que apresenta flores amarelas reunidas em cimeiras capituliformes guarnecidas por duas brácteas foliáceas, grandes, vermelhas e frutos obovóides, azuis. Floresce de outubro a dezembro e frutifica de janeiro a março. 
18.8. Psychotria prunifolia (Kunth) Steyerm., Memoirs of the New York Botanical Garden 23: 655. $1972 \equiv$ Cephaelis prunifolia Kunth, Nova Genera et Species Plantarum (quarto ed.) 3: 377. 1818. Figuras 113-115

Subarbusto, ca. $30 \mathrm{~m}$ alt. Ramos cilíndricos, pubescentes. Folhas verde amareladas, pecioladas, pecíolos semicilíndricos, 0,5-1 cm compr., pubescentes; lâmina elíptica, 4-6 × 2-4 cm, pubescente sobre as nervuras, nervuras primária e secundárias, proeminentes na superfície abaxial, 5-6 nervuras secundárias de cada lado, ápice agudo, base aguda, margem ondulada, ciliada; estípulas bipartidas, caducas, lanceoladas. Inflorescências 3-4-floras, pedúnculo reduzido 4-6 mm compr.; brácteas foliáceas formando um pseudo cálice, bractéolas lineares ciliadas; flores sésseis, distílicas, pentâmeras; cálice 3-4 mm compr., truncado, ciliado; corola tubulosa, amarela, 1,5-3 cm compr., externamente glabra, internamente com anel de tricomas próximo aos lobos triangulares, 1-1,5 mm compr., reflexos na flor em antese; estames inseridos na fauce ou no tubo da corola, inclusos ou exsertos; filete semicilíndrico 2-3 mm compr., anteras lanceoladas; ovário bilocular, um óvulo por lóculo; disco nectarífero inteiro, $0,6 \mathrm{~mm}$ compr.; estilete cilíndrico, incluso ou exserto $0,5-2 \mathrm{~cm}$ compr.; estigma bífido. Fruto drupáceo, globoso, 5-8 $\times$ 4-6 mm, preto, cálice persistente; sementes plano-convexa, superfície ventral plana com sulco longitudinal, superfície dorsal lisa.

Material examinado: BRASIL. Mato Grosso do Sul: Parque Estadual das Várzeas do Rio Ivinhema, 13-VII-2005, fr., Z.V. Pereira et al. 1355 (DDMS); idem, 15-VII-2005, fl., Z.V. Pereira et al. 1447 (DDMS).

Material adicional examinado: BRASIL. AmAZONAS: Manaus, Caracaraí, Km 63, 20-VIII-1976, fl., P.H. Davis \& D.F. Coelho 60354 (UEC). Distrito FederAL: Brasília, 10-VII-1976, fl., P.H. Davis et G.J. Shepherd 60106 (UEC).

Psychotria prunifolia distribui-se pela Colômbia, Peru e Brasil (Andersson 1992). No Brasil, ocorre nos Estados do Amazonas, Mato Grosso, Goiás, Minas Gerais e da Bahia até o Rio Grande do Sul (Andersson 1992). No PEVRI, foi registrada a primeira ocorrência para o Estado do Mato Grosso do Sul; foram amostradas poucas populações distribuídas na Mata Estacional Semidecidual do Parque.
No PEVRI, essa espécie é de fácil reconhecimento pelo porte subarbustivo, folhas verde amareladas, inflorescências com três ou quatro flores, brácteas foliáceas formando um pseudo cálice, corola amarela, lobos reflexo na flor em antese, fruto globoso, preto e sementes com superfície dorsal lisa. Floresce e frutifica de julho a dezembro.

18.9. Psychotria tenerior (Cham.) Mull., Arg. Flora

Brasiliensis 6(5): 331. $1881 \equiv$ Patabea tenerior

Cham., Linnaea 9: 236. 1835.

Figuras 116-119

Arbusto, ca. $60 \mathrm{~cm}$ alt. Ramos cilíndricos glabros. Folhas pecioladas, pecíolo semicilíndrico, 4-7 mm compr.; lâmina elíptico-lanceolada, 5-8 × 1,5-3 cm, glabra, nervuras primária e secundárias proeminentes na superfície abaxial, 5-7 nervuras secundárias de cada lado, ápice acuminado, base aguda, margem inteira; estípulas bipartidas, persistentes. Inflorescências em cimeiras paniculiformes, terminais, pedunculadas, pedúnculo verde 1-2,5 cm compr.; bractéolas lanceoladas, 0,5-1 cm compr.; flores sésseis, pentâmeras, distílicas; cálice 1-1,5 mm compr., lobos triangulares, 0,3-0,5 mm compr.; corola tubular, branca, 3-5 mm compr., externamente pubescente, internamente com anel de tricomas na região mediana, lobos lanceolados, 0,8-1 mm compr.; estames inseridos no tubo ou na fauce da corola, inclusos ou exsertos; filetes semicilíndricos 1-2 mm compr.; anteras lanceoladas; ovário bilocular, um óvulo por lóculo; disco nectarífero inteiro; estilete cilíndrico, incluso ou exserto, 1-5 mm compr., estigma bífido. Fruto drupáceo, globoso, preto, multissulcado, 3-5 × 2-6 mm, cálice persistente; sementes plano-convexas, superfície ventral plana com sulco longitudinal, superfície dorsal 4-costada.

Material examinado: BRASIL. Mato Grosso DO Sul: Parque Estadual das Várzeas do Rio Ivinhema, 4-I-2007, fl., fr., Z.V. Pereira et al.1680 (DDMS); idem, 5-II-2005, fr., Z.V. Pereira et al. 987 (DDMS).

Material adicional examinado: BRASIL. São Paulo: Campinas, 18-I-1995, fr., A.P. Spina 380 (IAC); Cananéia, Ilha do Cardoso, 18-III-1986, fl., S.A.C. Chiea s.n. (IAC); Mogi-Guaçú, Fazenda Campininha, 27-IX-1953, fl., M. Kuhlmann s.n. (IAC); Pariquera-Açú, Parque Estadual do Pariquera, 11-I-1999, fl., fr., J.R.L. Godoy et al. 73 (IAC).

Psychotria tenerior distribui-se pelo Brasil, Paraguai e Argentina (Andersson 1992). No Brasil, 


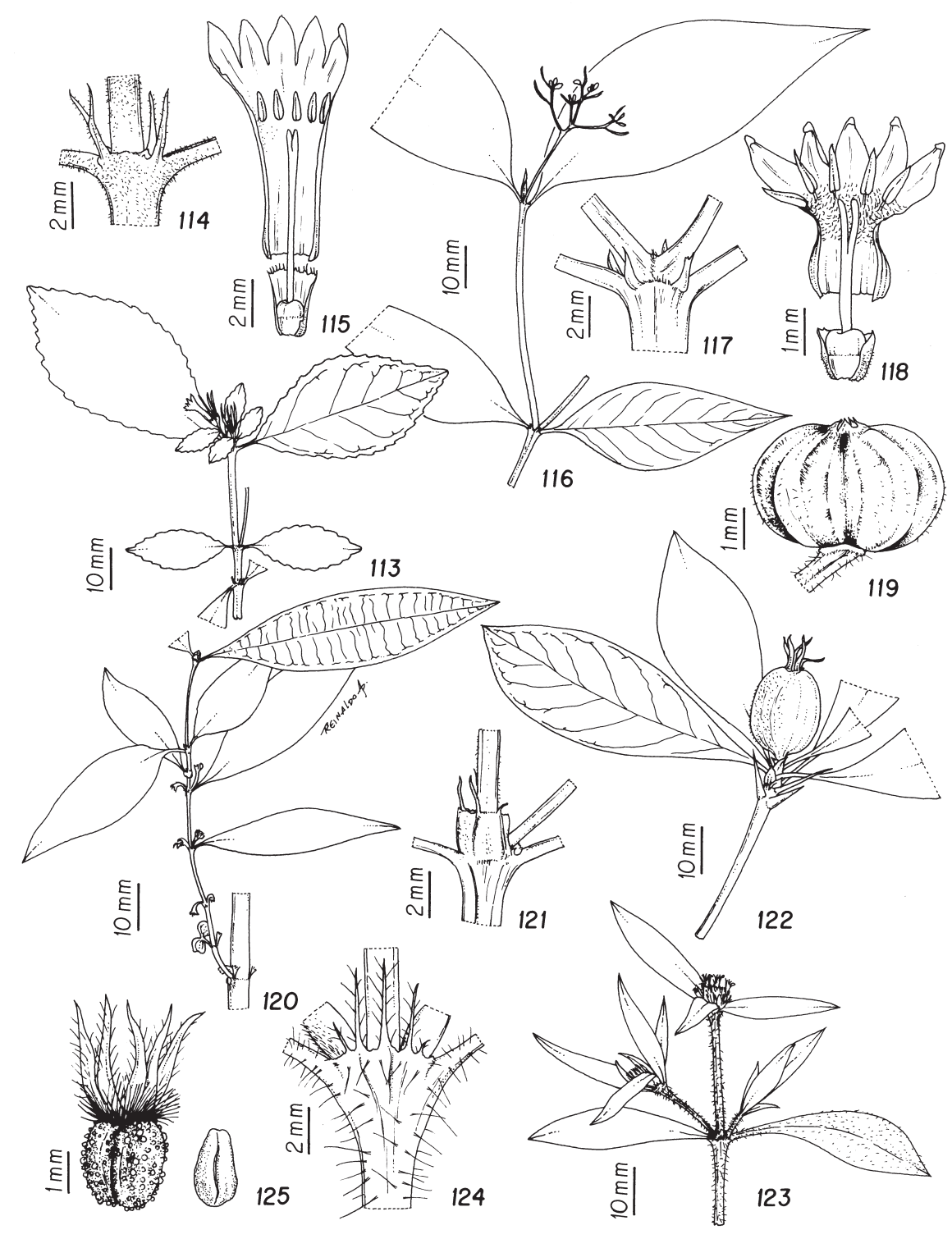

Figuras 113-125. Espécies de Rubiaceae do Parque Estadual das Várzeas do Rio Ivinhema, MS, Brasil. 113-115. Psychotria prunifolia (Z.V. Pereira et al. 1447). 113. Ramos com folhas, margem do limbo ondulada, inflorescência em cimeiras 3-4-floras. 114. Estípulas bipartidas lanceoladas. 115. Detalhe da flor dissecada. 116-119. Psychotria tenerior (Z.V. Pereira et al.1680). 116. Ramo com inflorescência em cimeira paniculiforme e brácteas lanceoladas. 117. Estípulas bipartidas. 118. Detalhe da flor dissecada. 119. Fruto drupáceo subgloboso, multissulcado. 120-121. Psychotria vellosiana (Z.V. Pereira \& G. Lobtchenko 1520). 120. Ramo com folhas evidenciando as nervuras secundárias paralelas e botões florais. 121. Estípulas conadas, bipartidas no ápice. 122. Randia armata (Z.V. Pereira et al. 1640). Ramo com folhas evidenciando espinhos e fruto. 123-125. Richardia brasiliensis (Z.V. Pereira et al. 585, 764). 123. Ramo com inflorescências em cimeiras glomeriformes, brácteas foliáceas. 124. Estípulas multifimbriadas. 125. Fruto esquizocárpico muricado e detalhe da semente.

Figures 113-125. Rubiaceae species of the Parque Estadual das Várzeas do Rio Ivinhema, Mato Grosso do Sul State, Brazil. 113-115. Psychotria prunifolia (Z.V. Pereira et al. 1447). 113. Branches with leaves, wavy blade margin, cymose, 3-4-flowered inflorescence; 114. Lanceolate, bipartite stipules; 115. Detail of dissected flower. 116-119. Psychotria tenerior (Z.V. Pereira et al.1680). 116. Branch with paniculiform, cyme inflorescence and lanceolate bracts; 117. Bipartite stipules; 118. Detail of dissected flower; 119. Drupaceous, subglobose, multi-furrowed fruit. 120-121. Psychotria vellosiana (Z.V. Pereira \& G. Lobtchenko 1520). 120. Branch with leaves showing parallel secondary veins and flower buds; 121 . Connate stipules, bipartite at apex. 122. Randia armata (Z.V. Pereira et al. 1640). Branch with thorns and leaves, showing fruit. 123-125. Richardia brasiliensis (Z.V. Pereira et al. 585, 764). 123. Branch with glomerulate, cyme inflorescence and foliaceous bracts; 124. Multi-fimbriate stipules; 125. Schizocarpous, muricate fruit, with detail of seed. 
pode ser encontrada em quase todo o território nacional (Andersson 1992). No PEVRI, foram amostrados vários indivíduos distribuídos nos fragmentos de transição, próximos à entrada do Parque. Pode ser reconhecida pelas bractéolas lanceoladas, com cerca de $1 \mathrm{~cm}$ de comprimento. Além disso, o tamanho reduzido da flor, corola branca, pubescente, fruto globoso e sementes 4-costadas constituem caracteres diagnósticos importantes. Floresce de outubro a janeiro e frutifica de dezembro a março.

\subsection{Psychotria vellosiana Benth., Linnaea 23:} 464. 1850.

Figuras 120, 121

Arbustos, ca. $3 \mathrm{~m}$ alt. Ramos cilíndricos, glabros ou puberulentos. Folhas pecioladas, pecíolo semicilíndrico, 5-7 mm, glabro, lâmina lanceolada, 4-9 × 1-2,5 cm, glabra, brilhante, nervura primária proeminente em ambas as superfícies, 20-25 nervuras secundárias de cada lado, paralelas, perpendiculares à nervura primária, ápice cuspidado, base atenuada, margem inteira; estípulas caducas, glabras, conadas, bipartidas no ápice. Inflorescências curto-pedunculadas, em cimeiras glomeriformes, multifloras, axilares, pedúnculos verdes, 3-5 mm compr.; brácteas triangulares, $4 \mathrm{~mm}$ compr.; flores sésseis, pentâmeras, distílicas; cálice $1 \mathrm{~mm}$ compr., lobos triangulares, ciliados; corola infundibuliforme, branca, 7-8,5 mm compr., externamente glabra, internamente com anel de tricomas na região mediana do tubo, lobos triangulares, 3-4 mm compr., ápices recurvados; estames inseridos na fauce ou no tubo da corola, inclusos ou exsertos, filetes achatados, 0,5-5 mm compr.; anteras lanceoladas; ovário bilocular, um óvulo por lóculo; disco nectarífero inteiro, $1 \mathrm{~mm}$ compr.; estilete cilíndrico, incluso ou exserto, 3-8 mm compr., estigma bífido. Fruto drupáceo, levemente comprimido, 4-6 × 2-3 mm, azul-escuro, cálice persistente; sementes plano-convexas, castanho-escuras, superfície ventral plana com sulco longitudinal, superfície dorsal 5-costada.

Material examinado: BRASIL. Mato Grosso do Sul: Parque Estadual das Várzeas do Rio Ivinhema, 15-XII-2005, fl. fr., Z.V. Pereira \& G. Lobtchenko 1520 (DDMS).

Material adicional examinado: BRASIL. MINAS GERAIS: Itamonte, 9-X-1982, fl., G. Hatschbach s.n. (UFG); Viçosa, 3-VII-2001, fr., Z.V. Pereira et al. 6 (VIC); Viçosa, 2-VIII-2002, fr., Z.V. Pereira et al. 91
(VIC). PARAná: São Jerônimo da Serra, 13-V-2002, fr., K.L.V.R. Sá et al. 212 (UFG); Ponta Grossa, 22-IX-1982, fl., G. Hatschbach s.n. (UFG).

Psychotria vellosiana distribui-se na Venezuela, Guiana, Suriname, Guiana Francesa, Trinidade Tobago, Brasil e Paraguai (Andersson 1992, Jung-Mendaçolli 1994). No Brasil, é encontrada na região central da Amazônia e Estados da Bahia, Espírito Santo, Minas Gerais, Rio de Janeiro, São Paulo, Mato Grosso do Sul, Paraná, Santa Catarina e Rio Grande do Sul (Andersson 1992). No PEVRI, foi encontrado apenas um indivíduo em um dos fragmentos de transição, próximo à entrada do Parque.

Psychotria vellosiana caracteriza-se pelas folhas com nervuras secundárias 20-25 de cada lado, paralelas, perpendiculares à nervura primária, glabras, inflorescências em cimeiras glomeriformes, axilares, fruto levemente comprimido, azul-escuro e semente com a superfície dorsal 5-costada. Floresce de setembro a dezembro e frutifica de novembro a abril.

19. Randia L., Species Plantarum 2: 1192. 1753.

Randia apresenta cerca de 90 espécies distribuídas do sudeste da Flórida, Texas, América Central, América do Sul e Antilhas (Gustafsson \& Persson 2002). No Brasil, ocorrem cerca de 12 espécies, distribuídas em quase todo o território nacional (Andersson 1992). No PEVRI, está representado apenas por Randia armata distribuída na mata ciliar à margem direita do rio Ivinhema.

As espécies desse gênero distinguem-se das demais pelos ramos frequentemente armados, estípulas pequenas, inteiras, inflorescências masculinas fasciculadas, paucifloras, femininas unifloras, terminais ou axilares, flores de 4-6-meras, prefloração contorcida, ovário de 1-3 lóculos, fruto bacáceo, globoso ou oval e sementes emersas na polpa, fixadas horizontalmente. No PEVRI, dos gêneros amostrados, somente Randia, Chomelia e Guettarda apresentam espinhos; contudo, Randia pode ser diferenciada pelas plantas unissexuais, dioicas, corola com prefloração contorcida e fruto bacáceo.

19.1. Randia armata (Sw.) DC., Prodromus Systematis

Naturalis Regni Vegetabilis 4: 387. 1830 = Gardenia armata Sw., Nova Genera et Species Plantarum seu Prodromus: 51. 1788.

Figura 122

Arbustos, 2-3 malt. Ramos cilíndricos, lenticelados, 4 espinhos por nó. Folhas pecioladas, congesta no 
ápice, pecíolo semicilíndrico, 3-5 mm compr., glabro, lâmina oblanceolada, 5-9 × 1,5-3,5 cm, pubescente sobre as nervuras, nervura primária e secundárias proeminentes em ambas as superfícies, 4-6 nervuras secundárias de cada lado, ápice acuminado, base aguda a atenuada, margem inteira; estípulas caducas, inteiras, triangulares. Inflorescências estaminadas fasciculadas, paucifloras, pistiladas unifloras, terminais; bractéolas triangulares, 3-5 mm compr.; flores sésseis, pentâmeras; cálice 4-6 mm compr., lobos lanceolados, pubescentes; corola tubular, branca, 2-3,5 cm compr., glabras, lobos oval-lanceolados, 0,5-1,5 cm compr.; estames inseridos no tubo da corola, inclusos, filetes semicilíndricos, 0,5-5 mm compr.; anteras elipsoides; ovário bicarpelar, unilocular, um óvulo por lóculo; disco nectarífero inteiro, 0,8-1 mm compr; estilete cilíndrico, exserto, 2,5-4 cm compr., estigma clavado. Fruto bacáceo, elipsóide, preto, 1,5-3 × 1-2 cm, cálice persistente, unisseminados; sementes suborbiculares, pardas, ocupando todo o lóculo.

Material examinado: BRASIL. Mato Grosso do Sul: Parque Estadual das Várzeas do Rio Ivinhema, 12-X-2006, fr., Z.V. Pereira et al. 1640 (DDMS); idem, 6-IX-2003, fr., Z.V. Pereira et al. 260 (DDMS); idem, 23-XI-2003, fl., Z.V. Pereira et al. 313 (DDMS); idem, 13-III-2004, fr., Z.V. Pereira \& G. Lobtchenko 437 (DDMS).

Material adicional examinado: BRASIL. BAHIA: Ipirá, 4-X-1986, fr., L.P. Queiroz et al. 973 (UFG). CEARÁ: Serra Grande, 22-X-1998, fr., P. Delprete et al. 6967 (UFG). GoIÁs: São Domingos, 9-V-1999, fr., A.P. Silva et al. 102 (UFG). Minas Gerais: Dionísio, 23-X-1976, fr., E.P. Heringer s.n. (UFG); Mata da Silvicultura, V-1994, fl, J.A.A. Meira-Neto s.n. (VIC).

Randia armata distribui-se pelo México e Antilhas e da Colômbia até o Brasil (Burger \& Taylor 1993). No Brasil, segundo Gustafsson (2004), essa espécie só ocorre na região amazônica. No PEVRI, foram registrados vários indivíduos distribuídos pela mata ciliar da margem direita do rio Ivinhema, sendo a primeira ocorrência constatada para o Mato Grosso do Sul.

No PEVRI, essa espécie é de fácil reconhecimento pelos ramos com quatro espinhos por nó, folhas congestas no ápice, estípulas inteiras, inflorescências estaminadas, fasciculadas, paucifloras, inflorescências pistiladas unifloras, terminais, corola branca com até
3,5 cm de comprimento, ovário bicarpelar, unilocular, com um único óvulo. Floresce de agosto a outubro e frutifica de outubro a janeiro.

20. Richardia L., Sp. P1. 1: 330. 1753.

Richardia compreende cerca de 15 espécies distribuídas nos Estados Unidos, México, América Central, Antilhas e América do Sul (Bacigalupo 1968, Porto et al. 1977, Dwyer 1980). No Brasil, está representado por oito espécies distribuídas de forma descontínua por todo o território brasileiro (Andersson 1992). No PEVRI, está representado por uma única espécie amplamente distribuída.

No PEVRI, Richardia apresenta os limites taxonômicos bem definidos, quando comparado com os demais gêneros da tribo Spermacoceae. Pode ser reconhecido pelas inflorescências providas de brácteas foliáceas ovais, ovário com três ou quatro carpelos e fruto esquizocárpico com o número de mericarpos igual ao de carpelos.

20.1. Richardia brasiliensis Gomes, Mem. Ipecacuanha Bras: 31. 1801.

Figuras 123-125

Ervas anuais ou perenes, ca. $30 \mathrm{~cm}$ alt. Ramos semicilíndricos, vilosos; Folhas pecioladas, pecíolo semicilíndrico, 1-1,5 cm compr.; lâmina oval-lanceoladas, $2-5 \times 1,5-2 \mathrm{~cm}$ hirsuta, nervura primária proeminente na superfície abaxial, sulcada na superfície adaxial, ápice agudo, base atenuada, margem inteira; estípulas 3-multi-fimbriadas. Inflorescências em cimeiras glomeriformes terminais, com 20 ou mais flores; brácteas foliáceas, ovais, hirsutas, dispostas em cruz; flores sésseis, hexâmeras; cálice 1-4 mm compr., lobos lanceolados, ciliados; corola infundibuliforme, branca, 4-7 mm compr., externamente com tricomas sobre os lobos, internamente com anel de tricomas no terço basal, lobos triangulares, 1,4-2 mm compr., ciliados; estames inseridos na fauce da corola, exsertos; filetes semicilíndricos, 1-1,5 mm compr.; anteras elipsoides; ovário tricarpelar, trilocular, um óvulo por lóculo; disco nectarífero inteiro; estilete cilíndrico, exserto, 1-1,3 cm compr.; estigma discoide. Fruto esquizocárpico com 3 mericarpos indeiscentes, obovóides, muricados, 2-4 × 1,52 mm, cálice persistente; sementes obovadas, plano-convexas, castanhas, superfície dorsal lisa, superfície ventral com sulco longitudinal.

Material examinado: BRASIL. Mato Grosso do Sul: Parque Estadual das Várzeas do Rio Ivinhema, 15-VIII-2003, fr., Z.V. Pereira et al. 764 (DDMS); 
idem, 10-VI-2004, fl., Z.V. Pereira et al. 585 (DDMS); idem, 6-IX-2003, fl., Z.V. Pereira et al. 274 (DDMS); idem, 6-IX-2003, fl., Z.V. Pereira et al. 232 (DDMS); idem, 10-IX-2005, fl., Z.V. Pereira et al. 1468 (DDMS); idem, 23-IV-2005, fl., Z.V. Pereira et al. 1285 (DDMS); idem, 9-II-2005, fl., Z.V. Pereira et al. 1011 (DDMS).

Material adicional examinado: BRASIL. Mato Grosso Do Sul: Corumbá, 4-X-1984 fl., C.A.C. 1616 (CGMS); Miranda, 4-XI-1990, fl., C.A.C. 2751 (CGMS). MATO Grosso: Porto Estrela, 27-II-2002, fl., U.M. Resende \& V. Kinupp 1640 (CGMS).

Richardia brasiliensis apresenta ampla distribuição, ocorrendo desde a América do Norte até América do Sul, além de ter sido introduzida na África e Ásia (Delprete et al. 2005). No Brasil, ocorre de forma descontínua em todos os Estados brasileiros (Andersson 1992). No PEVRI, ocorrem muitos indivíduos distribuídos próximo à sede e à estrada principal do Parque.

No PEVRI, essa espécie pode ser reconhecida pelo hábito herbáceo, prostrado, sendo densamente pilosa, com estípulas 3-5-cerdosas, inflorescências em cimeiras glomeriformes terminais, multifloras, com quatro brácteas foliáceas ovais dispostas em cruz, flores hexâmeras, e fruto esquizocárpico com mericarpos muricados e cálice persistente. Floresce e frutifica o ano todo.

21. Sabicea Aubl., Histoire des Plantes de la Guyane Française 1: 192. 1775.

Sabicea é composto de cerca de 106 espécies distribuídas pela América Tropical, África e Madagascar (Jung-Mendaçolli 2007). No Brasil, ocorrem 15 espécies distribuídas de forma irregular em quase todos os Estados brasileiros (Andersson 1992, Jung-Mendaçolli 2007). No PEVRI, está representada por $S$. villosa que ocorre na mata paludícola. As espécies desse gênero diferenciam-se das demais pelo hábito, estípulas inteiras, frequentemente reflexas, inflorescências em cimeiras axilares, flores pequenas, ovário 4-5-carpelar, placentação axial, estigma com quatro ou cinco ramos estigmáticos e fruto bacáceo, globoso, com muitas sementes pequenas, dispostas transversalmente.

21.1. Sabicea villosa Willd. ex Roem. \& Schult., Systema Vegetabilium 5: 265. 1819.

Figuras 126-128

Lianas. Ramos cilíndricos, hirsutos. Folhas pecioladas, pecíolo semicilíndricos, 2-2,5 cm compr., hirsutos; lâmina elíptico-lanceolada 7-11 × 4-6 cm compr., hirsuta, nervuras primária e secundárias proeminentes na superfície abaxial, 7-9 nervuras secundárias de cada lado, ápice agudo a acuminado, base aguda, margem inteira; estípulas persistentes, inteiras, obovadas, reflexas. Inflorescências em cimeiras corimbiformes compactas, curto-pedunculadas, pedúnculo 2-3 mm compr.; brácteas foliáceas, lanceoladas, hirsutas; flores sésseis, distílicas; cálice com cinco sépalas, 5-8 mm compr., lobos lanceolados, ciliados, 3-4 mm compr.; corola hipocrateriforme, creme, 7-10 mm compr., externamente pubescente, internamente com anel de tricomas na inserção dos estames, lobos ovais, 1-1,5 mm compr.; estames inseridos no tubo da corola, inclusos; filetes semicilíndricos, 2-3 mm compr.; anteras oblongas; ovário 4-5-locular, muitos óvulos por lóculos; disco nectarífero inteiro, 0,6-0,8 $\mathrm{mm}$ compr.; estilete cilíndrico, exserto, 2-3 mm compr.; estigma com 4-5 ramos. Fruto bacáceo, globoso ou subgloboso, vináceo, 7-12 × 5-8 mm, cálice persistente; sementes castanho-claras, pequenas, angulares, foveoladas.

Material examinado: BRASIL. Mato Grosso do Sul: Parque Estadual das Várzeas do Rio Ivinhema, 13-III-2005, fr., Z.V. Pereira et al. 1145 (DDMS); idem, 13-III-2005, fl., fr., Z.V. Pereira et al. 1146 (DDMS); idem, 13-VII-2005, fr., Z.V. Pereira et al. 1356 (DDMS).

Material adicional examinado: BRASIL. CEARÁ: Fazenda, 8-VII-1983, fl., fr., J.M. Poole 1705 (UFG). Maranhão: São Luiz, 28-VI-1983, fl., fr., R.H. Steven s.n. (UFG). Amazonas: Santo Antônio do Icá, 30-IV-1949, fl., R.L. Froes 25607 (IAC).

Sabicea villosa distribui-se no México, Antilhas, Brasil e Peru (Burger \& Taylor 1993). No Brasil, ocorre nos Estados do Amazonas, Bahia, Rio de Janeiro, Santa Catarina e Mato Grosso do Sul (Andersson 1992, Delprete et al. 2005, Jung-Mendaçolli 2007). No PEVRI, foram amostrados poucos indivíduos, no interior da mata paludícola. Caracteriza-se pelo hábito trepador, ramos hirsutos, estípulas inteiras, obovais, reflexas, inflorescências compactas, axilares, flores pequenas, estames inclusos, ovário 4-5-locular e estigma com 4-5 ramos estigmáticos. No PEVRI, floresce de outubro a fevereiro e frutifica de janeiro a julho.

22. Sipanea Aubl., Histoire des Plantes de la Guyane Française 1: 147, t. 56.1775.

Sipanea é um gênero neotropical, com cerca de 19 espécies distribuídas na América Central e América 
do Sul (Burger \& Taylor 1993). No Brasil, ocorrem oito espécies distribuídas de forma irregular em quase todos os Estados brasileiros exceto na região nordeste (Andersson 1992). No PEVRI, ocorre somente Sipanea hispida, encontrada nas várzeas próximas à entrada no Parque.

As espécies desse gênero podem ser reconhecidas pelo hábito herbáceo, inflorescências em cimeiras paniculiformes ou corimbiformes, 1-3-floras, corola hipocrateriforme, branca, rósea ou roxa, glabra ou vilosa, prefloração contorcida, e fruto cápsula loculicida com sementes pequenas, de superfície reticulada.

22.1. Sipanea hispida Benth. ex Wernham, Journal of Botany, British and Foreign 55: 173. 1917.

Figuras 129-132

Ervas perenes, eretas, $50 \mathrm{~cm}$ alt. Ramos cilíndricos, híspidos. Folhas subsésseis; lâmina elíptico-lanceolada, 2-4 × 1,5-2 cm, híspida, nervuras primária e secundárias proeminentes na superfície abaxial, ápice agudo, base obtusa, margem inteira; estípulas inteiras, ápices acuminados, persistentes. Inflorescências em cimeiras corimbiforme, 2-3-flora; brácteas lanceoladas; flores pediceladas; cálice 5 sépalas lanceoladas $4-8 \mathrm{~mm}$ compr.; corola hipocrateriforme, rósea, 1,2-2 cm compr., externa e internamente pilosa, lobos obtusos, 4-8 mm compr.; estames inseridos no tubo da corola, inclusos; anteras subsésseis, lanceoladas, amareladas; ovário bilocular, muitos óvulos por lóculo; disco nectarífero inteiro, estilete cilíndrico, inclusos, 2-3,5 mm compr.; estigma bífido. Fruto cápsula loculicida, ligeiramente lenhosa, 0,8-1,5 × 0,5-0,8 cm, cálice persistente; sementes pequenas arredondadas, castanho-escuras, foveoladas.

Material examinado: BRASIL. MAto Grosso DO Sul: Parque Estadual das Várzeas do Rio Ivinhema, 15-VIII-2003, fl., Z.V. Pereira et al. 738 (DDMS); idem, 15-VII-2003, fl., Z.V. Pereira et al. 752 (DDMS); idem, 11-IX-2004, fl., fr., Z.V. Pereira et al. 784 (DDMS); idem, 26-XII-2003, fl., Z.V. Pereira \& G. Lobtchenko 366 (DDMS); idem, 10-VI-2004, fl., fr., Z.V. Pereira et al. 588 (DDMS).

Material adicional examinado: BRASIL. AmAZONAS: São Gabriel da Cachoeira, 30-IV-1948, fl., G.A. Back 2453 (IAC). Mato Grosso Do Sul: Rodovia Campo Grande-Aquidauana Km 110, 14-XII-1976, fl., G.J. Shepherd et al. s.n. (UEC). GoIÁs: Chapada dos Veadeiros, Rio dos Brancos, 18-III-1976, fl., $J$. Semir s.n. (UEC).
Sipanea hispida distribui-se de forma descontínua na América do Sul (Andersson 1992). No Brasil, ocorre nos Estados do Amazonas, Bahia, Goiás, Minas Gerais, São Paulo, Mato Grosso do Sul, Paraná, Santa Catarina e Rio Grande do Sul (Anderson 1992). No PEVRI, ocorrem várias populações distribuídas em toda a região de várzeas na entrada do Parque. Essa espécie é de fácil reconhecimento pelo hábito herbáceo, folhas subsésseis, híspidas, inflorescência em cimeiras com 2-3 flores róseas, tubo corolineo com anel de tricomas amarelo no terço superior e fruto cápsula loculicida, com muitas sementes pequenas. Floresce e frutifica o ano todo.

23. Spermacoceodes Kuntze, Revisio Genera Plantarum 3(3): 123. 1898.

Spermacoceodes é um gênero monoespecífico, distribuído desde os Estados Unidos até o Rio da Prata (Bacigalupo 1974). No Brasil, distribui-se pelos Estados de Goiás, Mato Grosso do Sul, Bahia, Minas Gerais, Paraná, Santa Catarina e Rio Grande do Sul (Anderson 1992). No PEVRI, distribui-se nos varjões próximos à margem do rio Ivinhema. $\mathrm{O}$ gênero caracteriza-se por apresentar porte herbáceo, estípulas fimbriadas, ramos e folhas glabras, inflorescência em cimeiras glomeriformes, flores tetrâmeras, estames e estilete inclusos e fruto seco, indeiscente.

\subsection{Spermacoceodes glabrum (Michx.) Kuntze,}

Revisio Genera Plantarum 3(3): 123. $1898 \equiv$

Spermacoceglabra Michx., Flora Boreali-Americana 1: 82.1803.

Figuras 133-135

Ervas anuais ou perenes, eretas ou prostradas, 30-50 cm alt. Ramos tetragonais, glabros, avermelhados. Folhas sésseis, avermelhadas; lâmina lanceoladas, 2-3,5 × 0,5-0,8 cm glabras, nervura primária proeminente na superfície abaxial, nervuras secundárias inconspícuas, ápice agudo, base atenuada, margem inteira, ciliada; estípulas 4-5-fimbriadas. Inflorescências em cimeiras glomeriformes terminais e axilares; brácteas lanceoladas, esbranquiçadas; flores sésseis, tetrâmeras; cálice 1,5-2,5 mm compr., lobos lanceolados, $1 \mathrm{~mm}$ compr.; corola infundibuliforme, branca, 3-4 mm compr., externamente glabra, internamente com anel de tricomas no terço basal, lobos lanceolados, 1-1,2 mm compr.; estames inseridos na metade do tubo da corola, inclusos; filetes semicilíndricos, 0,6-1 mm compr.; anteras elipsoides; ovário bilocular, um óvulo por lóculo; 


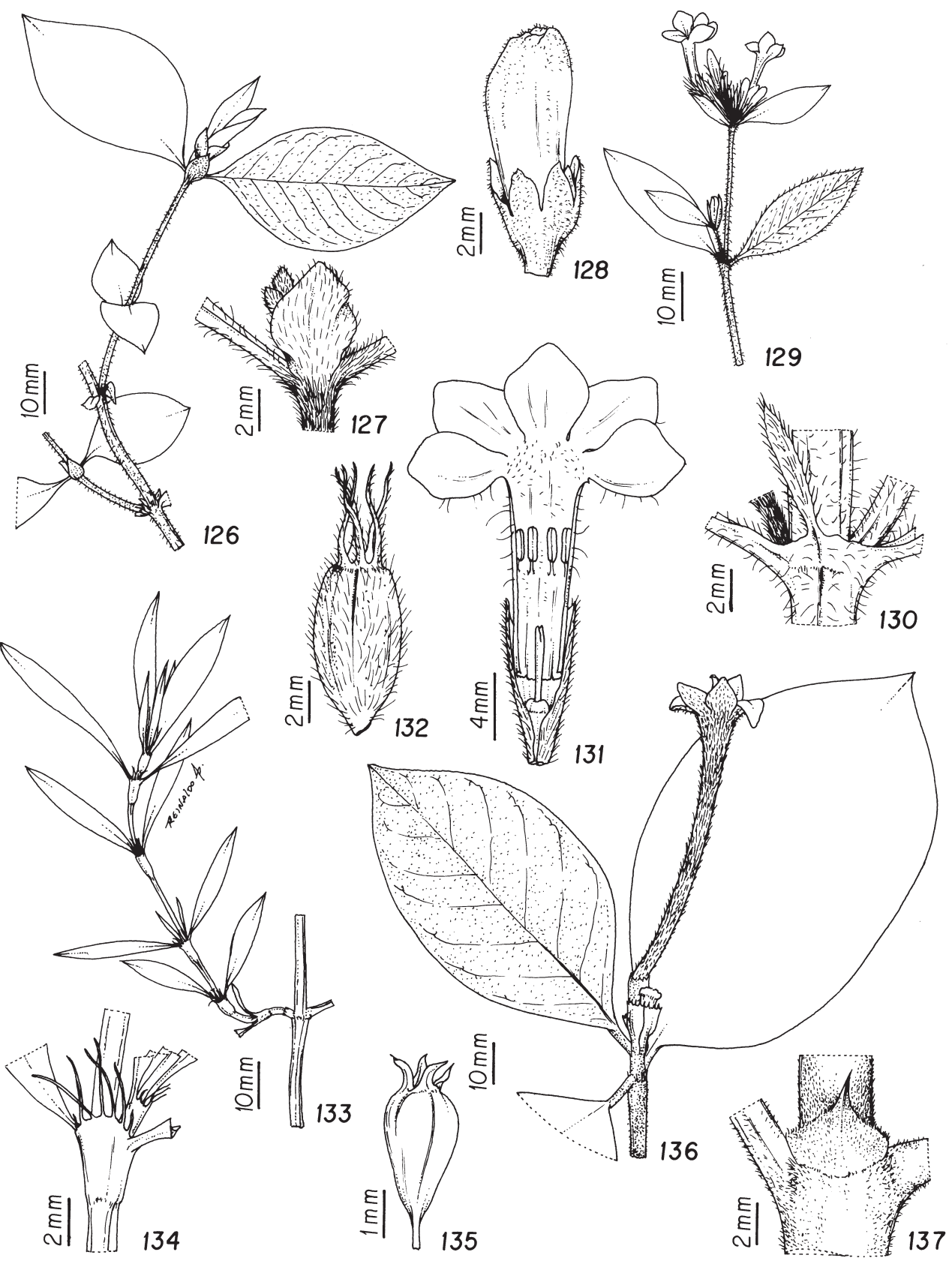

Figuras 126-137. Espécies de Rubiaceae do Parque Estadual das Várzeas do Rio Ivinhema, MS, Brasil. 126-128. Sabicea villosa (Z.V. Pereira et al. 1146). 126. Detalhe do ramo e estípulas reflexas. 127. Estípulas inteiras obovadas. 128. Detalhe do botão floral. 129-132. Sipanea hispida (Z.V. Pereira et al. 784). 129. Detalhe do ramo com inflorescência em cimeira corimbiforme. 130. Estípulas inteiras com ápice agudo. 131. Detalhe da flor dissecada. 132. Fruto cápsula loculicida. 133-135. Spermacoceodes grabrum (Z.V. Pereira et al. 1648). 133. Detalhe do ramo. 134. Estípulas fimbriadas. 135. Fruto seco indeiscente obovoide. 136-137. Tocoyena formosa (Z.V. Pereira et al. 500). 136. Detalhe das folhas e flor. 137. Estípulas inteiras com ápice agudo a acuminado.

Figures 126-137. Rubiaceae species of the Parque Estadual das Várzeas do Rio Ivinhema, Mato Grosso do Sul State, Brazil. 126-128. Sabicea villosa (Z.V. Pereira et al. 1146). 126. Details of the branch and reflexed stipules. 127. Entire, obovate stipules. 128. Detail of flower bud. 129-132. Sipanea hispida (Z.V. Pereira et al. 784). 129. Detail of branch with corymbiform, cyme inflorescence. 130. Entire stipules, with acute apex. 131. Detail of dissected flower. 132. Loculicidal capsule fruit . 133-135. Spermacoceodes grabrum (Z.V. Pereira et al. 1648). 133. Detail of branch. 134. Fimbriate stipules. 135. Obovoid, indehiscent dry fruit. 136-137. Tocoyena formosa (Z.V. Pereira et al. 500). 136. Detail of leaves and flower. 137. Entire stipules, acute to acuminate apex. 
disco nectarífero inteiro; estilete cilíndrico, incluso, 1-2 mm compr.; estigma bilobado. Fruto seco indeiscente, obovóide, glabro, 2-4 × 1-2 mm, cálice persistente, levemente comprimido longitudinalmente; sementes pardo-avermelhadas, plano-convexas, superfície ventral plana, superfície dorsal foveolada.

Material examinado: BRASIL. Mato Grosso Do Sul: Parque Estadual das Várzeas do Rio Ivinhema, 12-X-2005, fl., fr., Z.V. Pereira et al. 1648 (DDMS).

Material adicional examinado: ARGENTINA. Corrientes: Alvear, 7-II-1979, fl., A Schinimi et al. 16781 (IAC).

Spermacoceodes glabrum distribui-se pela América do Norte, América Central e América do Sul (Andersson 1992). No Brasil, ocorre nos Estados de Goiás, Mato Grosso do Sul, Bahia, Minas Gerais, Paraná, Santa Catarina e Rio Grande do Sul (Anderson 1992). No PEVRI, foram amostradas duas populações na margem direita do rio Ivinhema. Diferencia-se das outras espécies da tribo Spermacoceae pelas flores com estames e estilete inclusos, estigma bilobado e fruto indeiscente. Além disso, no PEVRI, é possível seu reconhecimento por ser densamente ramosa, e apresentar ramos e folhas avermelhados. Floresce e frutifica o ano todo.

24. Tocoyena Aubl., Histoire des Plantes de la Guyane Française 1: 131. 1775.

Tocoyena apresenta cerca de 20 espécies endêmicas da região neotropical, distribuídas desde o México até o Sul do Brasil (Prado 1987, Delprete et al. 2005). No Brasil, correm cerca de 12 espécies distribuídas em quase todo o território nacional (Andersson 1992). No PEVRI, está representada por Tocoyena formosa, encontrada somente na entrada do Parque. As espécies desse gênero podem ser reconhecidas pelo cálice com coléteres, tubo da corola longo, flores dispostas em cimeiras corimbiformes ou capituliformes, terminais, fruto bacáceo, amarelo e sementes plano-comprimidas, fixadas horizontalmente.

24.1. Tocoyena formosa (Cham. \& Schltdl.) K. Schum., FloraBrasiliensis 6(6):347. 1889 EGardenia formosa Cham. \& Schltdl., Linnaea 4: 200. 1829. Figuras 136, 137

Árvores ou arvoretas, 3-5 m alt. Ramos cilíndricos, velutinos. Folhas pecioladas, pecíolo semicilíndrico, 0,5-1,5 cm compr., velutino; lamina oblanceolada,
7-20 × 5,5-10 cm, velutina, nervuras primária e secundárias proeminentes na superfície abaxial, 7-11 nervuras secundárias de cada lado, ápice agudo a acuminado, base aguda, margem inteira; estípulas inteiras triangulares, ápice agudo. Inflorescências pedunculadas em cimeiras paucifloras, terminais; flores curto-pediceladas, pedicelo $0,5-0,6 \mathrm{~cm}$ compr., pentâmeras; cálice cupular, lobos curtos, $0,5 \mathrm{~cm}$ compr., com coleteres; corola hipocrateriforme, carnosa, amarela, 10-15 cm compr., hirsuta, lobos triangulares, 1-1,5 cm compr., reflexos na flor em antese; estames inseridos na fauce da corola; anteras semisséssil, lanceoladas; ovário bilocular, muitos óvulos por lóculos; disco nectarífero inteiro, 1-2 mm compr.; estilete cilíndrico, incluso, 10-13 cm compr.; estigma bífido. Fruto bacáceo, subgloboso, com estrias fibrosas, amarelo, pubérulo, 3-6 $\times 2,5-5 \mathrm{~cm}$, cálice persistente; sementes planas, dispostas horizontalmente, lisas.

Material examinado: BRASIL. Mato Grosso do Sul: Parque Estadual das Várzeas do Rio Ivinhema, 27-III-2004, fl., fr., Z.V. Pereira et al. 500 (DDMS).

Material adicional examinado: BRASIL. Mato Grosso Do Sul: Campo Grande, 10-I-1990, fr., C.A.C. 2545 (CGMS); Corumbá, 7-II-1994, fl., U.M. Resende 966 (CGMS); Corumbá, 25-XI-2001, fl., Damasceno Jr. et al. 3117 (CGMS); Nova Alvorada-Campo Grande, 24-I-2002, fr., A. Sciamarelli et al. 1380 (CGMS).

Esta espécie tem distribuição neotropical (Andersson 1992). No Brasil, distribui-se por todas as regiões brasileiras, habitando principalmente matas úmidas e secas, cerrados, caatingas, até áreas perturbadas (Prado 1987). No PEVRI, foram amostrados apenas dois indivíduos encontrados nos fragmentos de transição próximos à entrada do Parque.

Tocoyena formosa pode ser reconhecida, no campo, pelas folhas grandes $(7-20 \times 5,5-10 \mathrm{~cm})$, oblanceoladas, velutinas, folhas esbranquiçadas na superfície abaxial depois de secas, inflorescências paucifloras com flores grandes, fruto bacáceo, globoso, com muitas sementes fixadas horizontalmente. No PEVRI, floresce de novembro a março e frutifica de abril a setembro.

\section{Agradecimentos}

Ao Conselho Nacional de Desenvolvimento Cientifico e Tecnológico (CNPq), pela bolsa concedida à primeira Autora; à Dra. Charlotte M. Taylor, 
à Dra. Elza Cabral e ao Dr. Piero Delprete, pela confirmação da identificação de algumas espécies de Rubiaceae; às Dras. Sigrid Jung-Mendaçolli, Milene Faria Vieira, Eliana Regina Forni Martins e ao Dr. João Semir, pelas valiosas sugestões e ao Reinaldo Pinto, pelas ilustrações.

\section{Literatura citada}

Andersson, L.A. 1992. A provisional checklist of Neotropical Rubiaceae. Scripta Botanica Belgica 1: 1-199.

Andersson, L.A. \& Persson, C. 1991. Circumscription of the tribe Cinchoneae (Rubiaceae) - a cladistic approach. Plant Systematics Evolution 178: 65-94.

Anunciação, E.A. 1998. A família Rubiaceae Juss. na Serra da Juréia, São Paulo, Brasil. Dissertação de Mestrado, Universidade de São Paulo, São Paulo.

Bacigalupo, N.M. 1968. Revisón de las espécies del gênero Richardia (Rubiaceae) em la flora Argentina. Darwiniana 14: 639-53.

Bacigalupo, N.M. 1974. Rubiaceae. In: A. Burkart (ed.). Flora Ilustrada de Entre Rios, v.6. Instituto Nacional de Tecnología Agropecuaria, Buenos Aires, pp. 3-50.

Bacigalupo, N.M. \& Cabral, E.L. 1999. Revisón de las especies Americanas del gênero Diodia (RubiaceaeSpermacoceae). Darwiniana 37: 153-165.

Bacigalupo, N.M. \& Cabral, E.L. 2007. Rubiaceae Borreria G.F. Mey. In: T.S. Melhem, M.G.L. Wanderley, S.E. Martins, S.L. Jung-Mendaçolli, G.J. Shepherd \& M. Kirizawa (eds). Flora Fanerogâmica do Estado de São Paulo. FAPESP, São Paulo, v.5, pp. 276-284.

Bacigalupo, N.M. \& Cabral, E.L. 2007. Rubiaceae Richardia L. In: T.S. Melhem, M.G.L. Wanderley, S.E. Martins, S.L. Jung-Mendaçolli, G.J. Shepherd \& M. Kirizawa (eds). Flora Fanerogâmica do Estado de São Paulo. FAPESP, São Paulo, v.5, pp. 415-418.

Barbosa, M.R.V. 2007. Rubiaceae - Guettada L. In: T.S. Melhem, M.G.L. Wanderley, S.E. Martins, S.L. Jung-Mendaçolli, G.J. Shepherd \& M. Kirizawa (eds.). Flora Fanerogâmica do Estado de São Paulo. FAPESP, São Paulo, v.5, pp. 346-349.

Barbosa, M.R.V. \& Peixoto, A.L. 1989. As espécies de Simira (Rubiaceae, Rondeletieae) da Amazônia Brasileira. Acta Amazônica 19: 27-46

Barroso, G.M., Peixoto, A.L., Costa, C.G., Ichaso, C.L.F., Guimarães, F. \& Lima, H.C. 1991. Sistemática de Angiospermas do Brasil, 3 ed. Universidade Federal de Viçosa, Viçosa.

Brummitt, R.K. \& Powell, C.E. 1992. Authors of plant names. The Royal Botanic Gardens, Kew.

Burger, W. \& Taylor, C.M. 1993. Flora Costaricensis: Rubiaceae. Fieldiana 33: 1-333.
Cabral, E.L. 1991. Rehabilitacion del gênero Galianthe (Rubiaceae). Boletín de la Sociedad Argentina de Botánica 27: 235-249.

Cabral, E.L. 1996. Cuatro especies nuevas de Borreria (Rubiaceae) para la flora de Brasil. Bonplandia 9: 35-41.

Cabral, E.L. \& Bacigalupo, N.M. 1997. Revisión del gênero Galianthe subg. Ebelia stat. nov. (Rubiaceae: Spermacoceae). Annals of the Missouri Botanical Garden 84: 857-877.

Cabral, E.L. \& Bacigalupo, N.M. 2000. Novidades taxonômicas em Galianthe y Borreria (RubiaceaeSpermacoceae). Bonplandia 10: 119-128.

Campos, B.J. \& Souza, M.C. 1997. Vegetação. In: A.E.A.M. Vazzoler, A.A. Agostinho \& N.S. Hahn (eds.). A planície de inundação do Alto do rio Paraná. Editora da Universidade Estadual de Maringá, Maringá, pp. 331-342.

Costa, C.B. 2005. Revisão taxonômica de Coccocypselum (Rubiaceae). Tese de Doutorado, Universidade de São Paulo, São Paulo.

Costa, C.B. \& Mamede, M.C.H. 2002. Sinopse do gênero Coccocypselum P. Browne (Rubiaceae) no estado de São Paulo, Brasil. Biota Neotropica 2: 1-14.

Costa, C.B. \& Mamede, M.C.H. 2007 Rubiaceae Coccocypselum P. Browne. In: T.S. Melhem, M.G.L. Wanderley, S.E. Martins, S.L. Jung-Mendaçolli, G.J. Shepherd \& M. Kirizawa (eds.). Flora Fanerogâmica do Estado de São Paulo. FAPESP, São Paulo, v.5, pp. 292-298.

Delprete, P.G. 1999. Rondeletieae (Rubiaceae) Part I. Flora Neotropica Monograph 77: 1-226.

Delprete, P.G. 2006. A synopsis of the Rubiaceae of the states of Mato Grosso and Mato Grosso do Sul, Brazil, with a key to genera, and a preliminary species list. Revista de Biologia Neotropical 3: 13-96.

Delprete, P.G., Smith, L.B. \& Klein, R.M. 2004. Rubiaceae. In: A. Reis (ed.). Flora ilustrada Catarinense. Herbário Barbosa Rodrigues, Itajaí, v.1, pp. 1-345.

Delprete, P.G., Smith, L.B. \& Klein, R.M. 2005. Rubiaceae. In: A. Reis (ed.). Flora ilustrada Catarinense. Herbário Barbosa Rodrigues, Itajaí, v.2, pp. 346-842.

Dempster, L.T. 1982. The genus Galium in South America. III. Allertonia 3: 211-258.

Dempster, L.T. 1990. The genus Galium in South America. IV. Allertonia 5: 283-345.

Dessein, S. 2003. Systematic studies in the Spermacoceae (Rubiaceae). Tese de Doutorado, Katholieke Universiteit Leuven, Leuven.

Dillenburg, V.R. \& Porto, M.L. 1985. Rubiaceae, Tribo Psychotrieae. In: A.R.H. Schultz \& L.R.M. Baptista (eds.). Flora ilustrada do Rio Grande do Sul. Boletim do Instituto de Biociências 39: 1-76.

Dimitri, S.B. 1959. Rubiaceae da cidade do Rio de Janeiro: tribo Spermacoceae. Rodriguésia 22: 241-283. 
Dwyer, J.D. 1980. Rubiaceae. In: E.R. Woodson \& W.R. Schery (eds.). Flora of Panama. Annals of the Missouri Botanical Garden 67: 227-522.

Gentry, A.H. 1988. Changes in plant community diversity and floristic composition on environmental and geographical gradients. Annals of the Missouri Botanical Garden 75: 1-34.

Germano Filho, P. 1999. Estudos taxonômicos do gênero Bathysa C. Presl (Rubiaceae, Rondeletieae), no Brasil. Rodriguésia 50: 49-75.

Gomes, M. 2003. Reavaliação taxonômica de algumas espécies dos gêneros Coussarea Aubl. e Faramea Aubl. (Rubiaceae, tribo Coussareae). Acta Botanica Brasilica 17: 449-466.

Grisebach, A. 1879. Symbolae ad Floran argentinam. Dieterich'sche Verlagsbuchhandlung, Göttingen.

Gustafsson, C. 2004. Taxonomy and phylogeny of Randia (Rubiaceae, Gardenieae). Taxon 51: 661-674.

Gustafsson, C. \& Persson, C. 2002. Phylogenetic relationships among species of the neotropical genus Randia (Rubiaceae, Gardenieae) inferred from molecular and morphological data. Taxon 51: 661-674.

Holmgren, P.K., Holmgren, N.H. \& Barnett, L.C.E.K. 1990. Index herbariorum: the herbaria of the world Regnum Vegetabile v.120. New York Botanical Garden, New York.

IBGE. 1992. Manual técnico da vegetação brasileira. Série Manuais Técnicos em Geociências, Instituto Brasileiro de Geografia e Estatística, Rio de Janeiro.

Judd, W.S., Campbell, C.S., Kellogg, E.A., Stevens, P.F. \& Donoghue, M.J. 2002. Plant systematics: a phylogenetic approach. 2 ed. Sinauer Associates, Sunderland.

Jung-Mendaçolli, S.L. 1994. Flora fanerogâmica da Reserva do Parque Estadual das Fontes do Ipiranga (São Paulo, Brasil): Rubiaceae. Hoehnea 12: 97-129.

Jung-Mendaçolli, S.L. 1999. Rubiaceae. In: M.M.R.F. Melo, F. Barros, S.A.C. Chiea, M. Kirizawa, S.L. Jung-Mendaçolli, M.G.L. Wanderley. (eds.). Flora Fanerogâmica da Ilha do Cardoso, Instituto de Botânica, São Paulo, v.6, pp. 45-135.

Jung-Mendaçolli, S.L. 2003. Nova espécie de Galium L. (Rubiaceae) para o Estado de São Paulo, Brasil. Acta Botanica Brasilica 17: 605-608.

Jung-Mendaçolli, S.L. 2007. Rubiaceae - Galium L. In: T.S. Melhem, M.G.L. Wanderley, S.E. Martins, S.L. Jung-Mendaçolli, G.J. Shepherd \& M. Kirizawa (eds.). Flora Fanerogâmica do Estado de São Paulo. FAPESP, São Paulo, v.5, pp. 336-346.

Jung-Mendaçolli, S.L. 2007. Rubiaceae - Oldenlandia L. In: T.S. Melhem, M.G.L. Wanderley, S.E. Martins, S.L. Jung-Mendaçolli, G.J. Shepherd \& M. Kirizawa (eds.). Flora Fanerogâmica do Estado de São Paulo. FAPESP, São Paulo, v.5, pp. 378-379.
Jung-Mendaçolli, S.L. 2007. Rubiaceae - Sabicea Aubl. In: T.S. Melhem, M.G.L. Wanderley, S.E. Martins, S.L. Jung-Mendaçolli, G.J. Shepherd \& M. Kirizawa (eds.). Flora Fanerogâmica do Estado de São Paulo. FAPESP, São Paulo, v.5, pp. 431-434.

Kissmann, K G. \& Groth, D. 2000. Plantas infestantes e nocivas. v.3, 2 ed., BASF, São Paulo.

Lawrence, G.H.M. 1977. Taxonomia das plantas vasculares. Fundação Calouste Gulbenkian, Lisboa.

Lombardi, J.A. \& Gonçalves, M. 2000. Composição florística de dois remanescentes de Mata Atlântica do sudeste de Minas Gerais, Brasil. Revista Brasileira de Botânica 23: 255-282.

Mabberley, D.J. 1997. The plant-book: A portable dictionary of the vascular plants. Cambridge University Press, Cambridge.

Macias, L. 1998. Estudos taxonômicos do gênero Manettia Mutis ex L. (Rubiaceae) no Brasil, Paraguai, Argentina e Uruguai. Tese de Doutorado, Universidade Estadual de Campinas, Campinas.

Mato Grosso do Sul. Secretaria de Estado de Meio Ambiente - SEMA. 2001. Decreto 9.278, de 17 de dezembro de 1998. Decreto de criação do Parque das Várzeas do Rio Ivinhema. Diário Oficial de Mato Grosso do Sul, Campo Grande, pp.1-25.

Miotto, S.T.S. 1975. Revisão preliminar do gênero Borreria G.F.W. Meyer (Rubiaceae) no estado do Rio Grande do Sul. Iheringia 20: 17-25.

Missouri Botanical Garden. 2007. W3 Tropicos [on line]. http://www.mobot.mobot.org/w3t/Search/vast.html (acesso em 05.2007).

Muller-Agoviensis, J. 1881. Rubiaceae, Tribus I. Retiniphyleae, tribus II. Guettardeae, tribus III. Chiococeae, tribus IV. Ixoroideae, tribus V. Coussareae, tribus VI. Psychotrieae. In: C.F.P. Martius \& A.G. Eichler (eds.). Flora Brasiliensis, v.6, pp. $1-470$.

Muller-Agoviensis, J. 1888. Rubiaceae, Index voluinis VI. Partis V. In: C.F.P. Martius \& A.G. Eichler (eds.) Flora Brasiliensis, v.6, pp. 472-486.

Oliveira, H., Urchei, M.A. \& Fietz, C.R. 2000. Aspectos físicos e socioeconômicos da bacia hidrográfica do rio Ivinhema. Embrapa, Dourados.

Pereira, E. 1954. Contribuição ao conhecimento da família Rubiaceae. Chave artificial para determinação dos gêneros indígenas e exóticos mais cultivados no Brasil. Rodriguésia 17: 55-105.

Pereira, M.S. \& Barbosa, M.R. 2004. A família Rubiaceae na Reserva Biológica Guaribas, Paraíba, Brasil: Subfamílias Anterheoideae, Cinchonoideae e Ixoroideae. Acta Botanica Brasílica 18: 305-318.

Pereira, M.S. \& Barbosa, M.R.V. 2006. A família Rubiaceae na Reserva Biológica Guaribas, Paraíba, Brasil: subfamília Rubioideae. Acta Botanica Brasilica 20: 455-470. 
Pereira, M.S. \& Barbosa, M.R.V. 2009. Uma nova espécie de Coussarea Aubl. (Rubiaceae) para a Mata Atlântica no Estado da Bahia, Brasil. Acta Botanica Brasilica 23: 549-551.

Pereira, Z.V., Carvalho-Okano, R.M. \& Garcia, F.C.P. 2006. Rubiaceae Juss. da Reserva Florestal Mata do Paraíso, Viçosa, MG, Brasil. Acta Botanica Brasilica 20: 207-224.

Porto, M.L. \& Mariath, J.E.A. 1975. Taxonomia numérica de algumas entidades do gênero Relbunium (Endl.) Hook. fil. (Rubiaceae). Iheringia 20: 3-16.

Porto, M.L., Jaques, S.M.C., Miotto, S.T.S., Waechter, J.L. \& Detoni, M.L. 1977. Tribo Spermacoceae. Rubiaceae. In: A.R.H. Schultz \& M.H. Homrich (eds.). Flora Ilustrada do Rio Grande do Sul. Boletim do Instituto de Biociências 35: 1-114.

Prado, A.L. 1987. Revisão taxonômica do gênero Tocoyena Aubl. (Rubicaeae) do Brasil. Dissertação de Mestrado, Universidade Estadual de Campinas, Campinas.

Robbrechet, E. 1988. Tropical woody Rubiaceae. Opera Botanica Belgica 1: 1-127.

Royal Botanic Gardens. 1993. Index Kewensis on compact disc-manual. Oxford University Press, Oxford.

Schumann, K. 1888. Rubiaceae, tribus VII. Paederieae, tribus VIII. Spermacoceae, tribus IX. Stellatae. In: C.F.P. von Martius, A.G. Eichler \& I. Urban (eds.). Flora Brasiliensis, v.6, pp. 1-124.

Schumann, K. 1889. Rubiaceae, tribus X. Naucleeae, tribus XI. Henriquezieae, tribus XII. Cinchoneae tribus XIII. Rondeletieae, tribus XIV. Condamineeae, tribus XV. Hedyotideae, tribus XVI. Mussaendae, tribus XVII. Catesbaeeae tribus XVIII. Hamelieae, tribus XIX. Gardenieae. In: C.F.P. von Martius, A.G. Eichler \& I. Urban (eds.). Flora Brasiliensis, v.6, pp. 125-466.

Schumann, K. 1891. Rubiaceae. In: A. Engler \& K. Prantl (eds.). Die natürlichen Pflanzenfamilien 4: 1-156.

Smith, L.B. \& Downs, R.J. 1956. Resumo preliminar das Rubiaceae de Santa Catarina. Sellowia 7: 13-86.

Souza, E.B. 1997. Estudos taxonômicos dos gêneros Staelia Cham. \& Schltdl. e Mitracarpus Zucc. ex Roem. \& Schult. (Spermacoceae - Rubiaceae) no Estado de Pernambuco - Brasil. Dissertação de Mestrado, Universidade Federal Rural de Pernambuco, Recife.

Souza, E.B. \& Sales, M.F. 2002. Mitracarpus longicalyx (Rubiaceae, Spermacoceae), a new species from northeastern Brazil. Brittonia 53: 482-486.

Souza, E.B. \& Sales, M.F. 2004. O gênero Staelia Cham. \& Schltdl. (Rubiaceae - Spermacoceae) no Estado de Pernambuco, Brasil. Acta Botanica Brasilica 18: 919-926.

Steyermark, J.A. 1967. Rubiaceae. In: B. Maguire \& J.J. Wurdack (eds.). Botany of the Guayana Highlands, Part VII. Memoirs of the New York Botanical Garden 17: 230-436.
Steyermark, J.A. 1972. Palicourea. In: J.A. Steyermark $\&$ B. Maguire (eds.). Flora of the Guayana Highlands. Memoirs of New York Botanical Garden 23: 227-832.

Steyermark. J.A. 1974. Rubiaceae. In: T. Lasser (ed.). Flora da Venezuela. Instituto Botanico, Dirección de Recursos Naturales Renoables, Ministério de Agricultura y Cría, Caracas, v.9. pp.1-2070.

Sucre, D. 1959. Rubiaceae da cidade do Rio de Janeiro I, Tribo Spermacoceae. Rodriguésia 33: 241-280.

Sucre, D. 1960-1961. Estudo das Rubiaceae brasileiras I. Rodriguésia 35: 11-20.

Sucre, D. 1971. Estudos das Rubiaceae brasileiras III, cinco novas espécies da tribo Spermacoceae. Rodriguésia 38: 253-260.

Taylor, C.M. 1989. Revision of Palicourea (Rubiaceae) in Mexico and Central America. Systematic Botany Monographs 26: 1-102.

Taylor, C.M. 1994. Taxonomic notes on Psychotria (Rubiaceae) in Western South America. Novon 4: 303-306.

Taylor, C.M. 1997. Conspectus of the genus Palicourea (Rubiaceae: Psychotrieae) with the description of some new species from Ecuador and Colombia. Annals of the Missouri Botanical Garden 84: 224-262.

Taylor, C.M. 2007. Rubiaceae - Pschotria L. In: T.S. Melhem, M.G.L. Wanderley, S.E. Martins, S.L. Jung-Mendaçolli, G.J. Shepherd \& M. Kirizawa (eds.). Flora Fanerogâmica do Estado de São Paulo. FAPESP, São Paulo, v.5, pp. 389-411.

Taylor, C.M., Campos, M.T.V.A. \& Brito, J.M. 1999. Rubiaceae. In: J.E.L.S. Ribeiro, M.J.G. Hopkins, A.Vicentini, C.A. Sothers, M.A.S. Costa, J.M. Brito, M.A.D. Souza, L.H.P. Martins, L.G. Lohmann, P.A.C.L Assunção, E.C. Pereira, C.F. Silva, M.R. Mesquita \& L.C. Procópio (eds.). Flora da Reserva Ducke: Guia de identificação das plantas vasculares de uma floresta de terra-firme na Amazônia Central. Instituto Nacional de Pesquisas da Amazônia, Manaus.

Terrell, E.F., Wunmugam, J. \& Rafi, M.M. 2002. Seed and fruit characters in selected Spermacoceae and comparison with Hedyotideae (Rubiaceae). Sida 20: 549-557.

Veloso, H.P., Rangel Filho, AR. \& Lima, J.C.A. 1991. Classificação da vegetação brasileira, adaptada a um sistema universal. Instituto Brasileiro de Geografia e Estatística, Rio de Janeiro.

Vercourt, B. 1976. Rubiaceae (Part I). In: R.M. Polhill (ed.). Flora of Tropical East Africa. Whitefriars Press, London, pp. 1-414.

Zappi, D. \& Nunes, T.S. 2000. Notes on the Rubiaceae of northeastern Brasil. I. Erithalis, Psychotria and Rudgea. Kew Bulletin 55: 655-668. 